Universidade de São Paulo

Escola de Comunicações e Artes

Rosana Mauro

\title{
ASPECTOS DA MIDIATIZAÇÃO DO CONSUMO E DO SENTIDO DE CLASSE SOCIAL NA TELENOVELA: a representação da "nova classe C"
}


Rosana Mauro

ASPECTOS DA MIDIATIZAÇÃO DO CONSUMO E DO SENTIDO DE CLASSE SOCIAL NA TELENOVELA: a representação da "nova classe C"

Dissertação apresentada à Escola de Comunicações e Artes da Universidade de São Paulo para obtenção do título de Mestre em Ciências da Comunicação.

Área de Concentração: Estudos dos Meios e da Produção Mediática.

Linha de Pesquisa: Consumo e Usos Midiáticos nas Práticas Sociais.

Orientador: Prof. Dr. Eneus Trindade Barreto Filho 
Autorizo a reprodução e divulgação total ou parcial deste trabalho, por qualquer meio convencional ou eletrônico, para fins de estudo e pesquisa, desde que citada a fonte.

Catalogação da publicação

Departamento de Relações Públicas, Propaganda e Turismo

Escola de Comunicações e Artes da Universidade de São Paulo

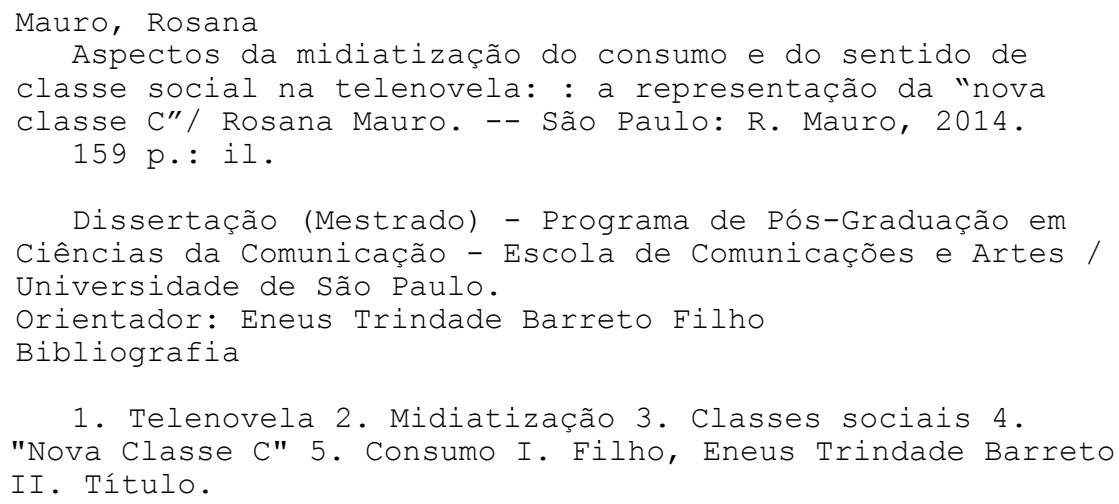


Nome: MAURO, Rosana

Título: Aspectos da midiatização do consumo e do sentido de classe social na telenovela: a representação da "nova classe C"

Dissertação apresentada à Escola de Comunicações e Artes da Universidade de São Paulo para obtenção do título de Mestre em Ciências da Comunicação.

Aprovado em:

\section{Banca Examinadora:}

Prof. Dr. Instituição:

Julgamento: Assinatura:

Prof. Dr. Instituição:

Julgamento: Assinatura:

Prof. Dr. Instituição:

Julgamento: Assinatura: 


\section{DEDICATÓRIA}

À minha família que é muito presente em minha vida, sempre amorosa, e me apoiou em todos os aspectos para a realização desta dissertação de mestrado, minha mãe Djanira Messias Mauro, meu pai Renato Mauro, minhas irmãs Luciana Rita Mauro e Eliza Mauro. Ao carinho dos meus queridos animais de estimação, que silenciosamente me fizeram companhia nas madrugadas de escrita e tornam, assim, minha rotina mais doce. 


\section{AGRADECIMENTOS ESPECIAIS}

Ao professor Dr. Eneus Trindade Barreto Filho, pela oportunidade de cursar o mestrado sob sua orientação, por ter me guiado na busca de um caminho próprio de pesquisa e ter confiado no meu trabalho e potencial em todos os momentos do mestrado, nas diversas atividades acadêmicas que me foram propostas.

À comissão de bolsas da ECA/CNPq pelo financiamento desta pesquisa, que além de ter sido fundamental economicamente, me proporcionou uma motivação extra.

Aos docentes da linha de pesquisa "Consumo e Usos Midiáticos nas Práticas Sociais", Dra. Clotilde Perez e Dr. Leandro Batista, pela atenção, conselhos e oportunidades de participação em atividades acadêmicas.

À professora Dra. Maria Cristina Palma Mungioli, cuja disciplina por mim cursada foi de grande contribuição para a realização desta dissertação, e cujas críticas construtivas no Exame de Qualificação foram essenciais para o ajustamento do trabalho.

À professora Dra. Marcia Perencin Tondato pela participação no meu Exame de Qualificação e pelas importantes observações e críticas que contribuíram para a concretização deste trabalho.

À professora Dra. Roseli Aparecida Fígaro Paulino, pela postura crítica inspiradora e cuja disciplina "Comunicação no Mundo do Trabalho: Recepção e Mediações" trouxe aprendizados teóricos fundamentais para o embasamento desta dissertação.

Aos amigos do PPGCOM Alhen Rubens Damasceno, Cinira Baader, Cristina Dias, Diogo Kawano, Flavia Gonsales, Lívia Silva de Souza, Nicolás Llano Linares e Rafael Grohmann, pelos trabalhos realizados em conjunto, pelos conselhos de pesquisa, pela companhia, apoio e por terem compartilhado momentos importantes da minha trajetória de mestrado. 
MAURO, Rosana. Aspectos da midiatização do consumo e do sentido de classe social na telenovela: a representação da "nova classe C". 2014. 159 f. Dissertação (Mestrado)

- Escola de Comunicações e Artes, Universidade de São Paulo, São Paulo, 2014.

\section{RESUMO}

A presente pesquisa pretende estudar aspectos da midiatização do consumo e do sentido de classe social na telenovela com foco na representação do que vem sendo considerada a "nova classe C" ou "nova classe média" brasileira. Para tanto, analisou-se cenas das telenovelas Avenida Brasil (2012), de João Emanuel Carneiro, e Cheias de Charme (2012), de Filipe Miguez e Izabel de Oliveira. Ambas exibidas na Rede Globo, a primeira no horário das 21 horas e a segunda às 19 horas. As duas foram consideradas pela mídia como tramas que representam a "nova classe C", o que justifica a escolha. Inicialmente, o trabalho traz uma breve discussão teórica sobre o termo midiatização, sobre as concepções sociológicas de classe social e os estudos realizados sobre telenovela e classe. Pretende-se, assim, problematizar a expressão "nova classe C", de modo a entender sua natureza e validade sociológica, bem como levantar a forma como a telenovela costuma retratar as classes sociais, para, assim, rumar às análises com embasamento teórico. A metodologia de análise se fundamenta na concepção marxista de materialismo histórico e dialética, com a qual estão relacionadas as teorias do filósofo da linguagem Mikhail Bakhtin, a Análise do Discurso Francesa e a Análise do Discurso Crítica. Essas teorias tiveram alguns de seus elementos mesclados e utilizadas como protocolo metodológico. A partir do protocolo e dos levantamentos teóricos sobre classes sociais e telenovela, objetiva-se averiguar as nuanças da midiatização do consumo e do sentido de classe social na representação discursiva do que vem sendo chamada a "nova classe C" em cenas selecionadas de Avenida Brasil e Cheias de Charme. Com as análises das cenas que retratam situações que aludem ao consumo, obtivemos resultados que apontam para o fato de ambas as telenovelas, em diferentes graus, apresentarem em seus discursos características que condizem com o modo próprio da telenovela tratar as classes sociais, assim como elementos que se relacionam com uma visão social hegemônica, além de aspectos que estão conectados com a realidade comentada pelos sociólogos e que também indicam mudanças na forma usual das telenovelas retratarem as diferenças sociais. Ademais, de acordo com o conceito de midiatização e com o papel da telenovela no Brasil, acreditamos que essas representações contribuem para a formação de um conhecimento social do que seria a "nova classe C" brasileira.

PALAVRAS-CHAVE: Telenovela; midiatização; classes sociais; "nova classe C"; consumo; discurso. 
MAURO, Rosana. Aspects of the mediatization of consumption and the sense of social class in telenovela: the representation of the "new class C". 2014. $159 \mathrm{f}$. Dissertação (Mestrado) - Escola de Comunicações e Artes, Universidade de São Paulo, São Paulo, 2014.

\begin{abstract}
This search aims to study aspects of the mediatization of consumption and the sense of social class in telenovela, with focus on what is dubbed "the new class C" or "new middle class" in Brazil. For that purpose, it was analyzed scenes of the telenovelas Avenida Brasil (2012), by João Emanuel Carneiro, and Cheias de Charme (2012), by Filipe Miguez and Izabel de Oliveira. Both were aired in Rede Globo, at 9pm. and $7 \mathrm{pm}$., respectively. These two productions were considered by the media as representative of the "new class C", which justifies the choice. Initially, this work brings a brief theoretical discussion about the mediatization concept, about the sociologic concept of social class and the studies which cover telenovela and social class altogether. It is intended, therefore, to problematize the expression "new class C", in order to understand its origin and sociologic nature, as well as to look at the manner by which the telenovela usually portrays the social classes, so as to produce an analysis which has theoretical base. The methodology to analyze the matter is based on the Marxist conception of dialectic and in the historical materialism, which are related to the theories of the Russian language philosopher Mikhail Bakhtin, the French Discourse Analysis and Critical Discourse Analysis. These theories had some of their elements combined and used as methodological protocol. From methodological protocol and from the theoretical points about social classes and telenovelas, the objective is to investigate the nuances of the mediatization of consumption and the sense of social class in the discursive representations of the dubbed "new class C" in scenes picked from Avenida Brasil and Cheias de Charme. Based on the analysis of scenes that portray situations that allude to consumption, we obtained results which demonstrate that both telenovelas, yet in different degrees, reveal in their plots characteristics that connect with the particular view with which the telenovela approaches the social classes, as well as with elements that are related with the hegemonic social view, apart from aspects that are connected with the reality commented by sociologists and which indicates changes in the usual way that the telenovela portrays the social differences. Moreover, according to the concept of mediatization as well as to the role of telenovela in Brazil, we believe that those representations contribute to the making of a social knowledge of what the new Brazilian "new class C" would be.
\end{abstract}

KEYWORDS: Telenovela; mediatization; social classes; "new class C"; consumption; discourse. 


\section{LISTA DE FIGURAS}

Figura 1 - Retirada do site oficial da telenovela Avenida Brasil. Fonte: http://gshow.globo.com/novelas/avenida-brasil/capitulo/2012/4/5/ivana-apresentacarminha-a-nina.html

Figura 2 - Retirada do site oficial da telenovela Avenida Brasil. Fonte: http://gshow.globo.com/novelas/avenida-brasil/capitulo/2012/4/5/ivana-apresentacarminha-a-nina.html

Figura 3 - Retirada do site oficial da telenovela Avenida Brasil. Fonte: http://gshow.globo.com/novelas/avenida-brasil/capitulo/2012/4/5/ivana-apresentacarminha-a-nina.html

Figura 4 - Retirada do site oficial da telenovela Avenida Brasil. Fonte: http://gshow.globo.com/novelas/avenida-brasil/capitulo/2012/7/23/nilo-afirma-quemax-esta-apaixonado-por-nina.html.

Figura 5 - Retirada do site oficial da telenovela Avenida Brasil. Fonte: http://gshow.globo.com/novelas/avenida-brasil/capitulo/2012/7/23/nilo-afirma-quemax-esta-apaixonado-por-nina.html

Figura 6 - Retirada do site oficial da telenovela Avenida Brasil. Fonte: http://gshow.globo.com/novelas/avenida-brasil/capitulo/2012/9/17/nina-deixa-claropara-tufao-que-ama-outro-homem.html.

Figura 7 - Retirada do site oficial da telenovela Avenida Brasil. Fonte: http://gshow.globo.com/novelas/avenida-brasil/capitulo/2012/9/17/nina-deixa-claropara-tufao-que-ama-outro-homem.html.

Figura 8 - Retirada do site oficial da telenovela Cheias de Charme. Fonte: http://gshow.globo.com/novelas/cheias-de-charme/capitulo/2012/4/16/cida-rosario-epenha-fazem-um-pacto.html

Figura 9 - Retirada do site oficial da telenovela Cheias de Charme. Fonte: http://gshow.globo.com/novelas/cheias-de-charme/capitulo/2012/4/16/cida-rosario-epenha-fazem-um-pacto.html

Figura 10 - Retirada do site oficial da telenovela Cheias de Charme. Fonte: http://gshow.globo.com/novelas/cheias-de-charme/capitulo/2012/4/16/cida-rosario-epenha-fazem-um-pacto.html 
Figura 11 - Retirada do site oficial da telenovela Cheias de Charme. Fonte: http://gshow.globo.com/novelas/cheias-de-charme/capitulo/2012/7/14/fabian-apareceno-orfanato-e-surpreende-rosario.html

Figura 12 - Retirada do site oficial da telenovela Cheias de Charme. Fonte: http://gshow.globo.com/novelas/cheias-de-charme/capitulo/2012/7/14/fabian-apareceno-orfanato-e-surpreende-rosario.html.

Figura 13 - Retirada do site oficial da telenovela Cheias de Charme. Fonte: http://gshow.globo.com/novelas/cheias-de-charme/capitulo/2012/7/14/fabian-apareceno-orfanato-e-surpreende-rosario.html

Figura 14 - Retirada do site oficial da telenovela Cheias de Charme. Fonte: http://gshow.globo.com/novelas/cheias-de-charme/capitulo/2012/7/14/fabian-apareceno-orfanato-e-surpreende-rosario.html

Figura 15 - Retirada do site oficial da telenovela Cheias de Charme. Fonte: http://gshow.globo.com/novelas/cheias-de-charme/capitulo/2012/7/23/socorro-falapara-chayene-que-sabe-como-separar-as-empreguetes.html

Figura 16 - Retirada do site oficial da telenovela Cheias de Charme. Fonte: http://gshow.globo.com/novelas/cheias-de-charme/capitulo/2012/7/23/socorro-falapara-chayene-que-sabe-como-separar-as-empreguetes.html.

Figura 17 - Retirada do site oficial da telenovela Cheias de Charme. Fonte: http://gshow.globo.com/novelas/cheias-de-charme/capitulo/2012/7/23/socorro-falapara-chayene-que-sabe-como-separar-as-empreguetes.html 


\section{SUMÁRIO}

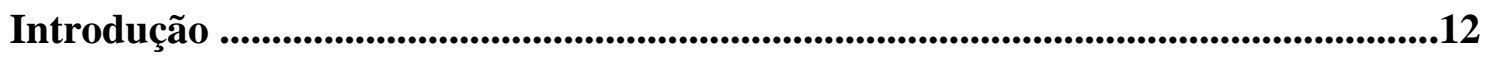

1 Telenovela, midiatização do consumo e do sentido de classe..........................16

1.1. Do folhetim à midiatização, contexto representacional da ascensão financeira e de consumo

1.2. Considerações teóricas sobre classe social e estudos sobre sua representação na telenovela.....

1.3. Aspectos preliminares da midiatização do consumo e do sentido de classe em Avenida Brasil e Cheias de Charme.

2 Análise Discursiva para o estudo da midiatização do consumo e do sentido

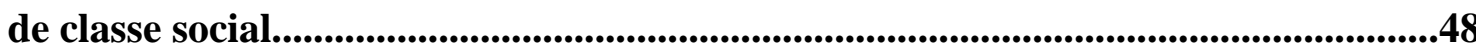

2.1. Linguagem e discurso, caráter sócio-histórico e dialético

2.2. Discurso como prática social, significação representacional, identificacional e acional.

2.3. Protocolo de análise

3 Avenida Brasil e Cheias de Charme, as nuanças da midiatização do consumo

e do sentido de classe. .79

3.1. Contexto narrativo de Avenida Brasil

3.2. Elementos da representação discursiva da nova classe trabalhadora em Avenida

Brasil. . .84

3.3. Contexto narrativo de Cheias de Charme.

3.4. Elementos da representação discursiva da nova classe trabalhadora em Cheias de Charme

Considerações finais

Referências 


\section{INTRODUÇÃO}

Esta dissertação de mestrado é resultado de um processo de pesquisa que foi amadurecendo ao longo do tempo. Muito embora o objeto telenovela tenha sido o foco desde o início, o projeto de pesquisa como aqui está proposto emergiu das descobertas teóricas e empíricas na trajetória do mestrado.

O intuito inicial era estudar a produção de sentido de consumo das representações femininas na telenovela. A intenção da pesquisa estava, na época, embalada no desejo de estudar o modo como as tramas incitam a vontade de consumir, por meio de seus personagens, cenários, figurinos, independente de ações de publicidade. Assim como já ocorria na época dos folhetins.

A ideia persistiu por um tempo, mas não foi possível me manter cega às demandas do próprio objeto, reveladas pelo momento histórico e social da telenovela, em especial no ano de 2012. A ascensão financeira de uma camada da população brasileira repercutida nas representações da teleficção não pôde passar despercebida. Novas descobertas e encantamentos guiaram a pesquisa.

É importante expor que cresci assistindo a telenovelas e assim continuo. Por meio das lembranças de tramas já assistidas consigo, inclusive, recordar das minhas próprias vivências, tamanha é a relação entre vida e ficção e entre o Brasil e a telenovela, dada a importância desse produto midiático em nossa cultura. Desse modo, deixei que as tramas falassem por si e me conduzissem nessa trajetória.

No início, o estudo se concentraria nas telenovelas Fina Estampa (2011/2012) de Aguinaldo Silva, Avenida Brasil (2012) de João Emanuel Carneiro e Cheias de Charme (2012) de Filipe Miguez e Izabel de Oliveira. A três foram transmitidas na Rede Globo, as duas primeiras no horário das 21 horas e a última às 19 horas. A Análise do Discurso Francesa seria a metodologia para analisar as representações de consumo, que dividiria a atenção com mais um interesse da pesquisa - a transmidialidade.

Porém, não demorou muito para que Avenida Brasil e Cheias de Charme (Fina Estampa já havia terminado quando a pesquisa teve início de fato) mostrassem que a temática classe social estava ali querendo ser ouvida. Permitiu-se a mudança. Novas leituras, novos olhares tiveram lugar e não tardou também para que a Análise do Discurso Crítica (ADC) se mostrasse pertinente como metodologia, junto de elementos da Análise do Discurso Francesa. 
Com o tempo, a pesquisa foi tomando forma. As disciplinas cursadas trouxeram grandes contribuições e a orientação que me foi concedida permitiu também a descoberta de um caminho de pesquisa próprio.

A temática da transmidialidade se mostrou excessiva para o recorte pretendido e para os limites de tempo do trabalho e, assim, o foco passou a ser a midiatização do consumo e do sentido de classe social nas telenovelas Avenida Brasil e Cheias de Charme, visto que em Fina Estampa o tema em questão não se mostrou tão proeminente.

O termo midiatização se fez relevante para a pesquisa, pois ele abarca a importância cada vez maior da mídia em nossa sociedade e as mudanças acarretadas por essa centralidade midiática. No caso da telenovela no Brasil, a midiatização é um conceito pertinente devido ao papel que as tramas assumem socialmente, na construção de um imaginário nacional, ao trazerem representações sociais diversas, sobretudo de classe sociais. O termo será devidamente teorizado no primeiro capítulo desta dissertação.

É importante relatar que no período de transmissão de Avenida Brasil e Cheias de Charme, a mídia jornalística noticiou o fato das tramas estarem representando a "nova classe C" brasileira. Muito se falou sobre o assunto. As notícias percorreram não só o Brasil, mas também a mídia exterior. Tal fato trouxe para a pesquisa a pergunta sobre como estaria sendo realizada essa representação.

Seria preciso, então, desconstruir a expressão "nova classe C" para entender sua representação. O que dizem os sociólogos sobre a nomenclatura? Como a telenovela retratou essa nova classe? O que há de puramente midiático nessa representação? O que condiz com os argumentos sociológicos? O que corrobora com a visão econômica hegemônica e o que aponta para mudanças?

Essas são as questões apresentadas por este trabalho. O objetivo é, primeiramente, propor uma reflexão teórica sobre classes sociais e estudos que abordam sua representação na telenovela para, a partir disso, tentar responder as perguntas propostas com a análise discursiva de cenas selecionadas de Avenida Brasil e Cheias de Charme, por meio de um protocolo que mescla a Análise do Discurso Francesa e a Análise do Discurso Crítica (ADC), além de considerar importantes conceitos do filósofo russo da linguagem Mikhail Bakhtin.

O trabalho proposto se justifica, entre outros aspectos, pela importância cultural da telenovela em nosso país. Com a ascensão econômica de uma parte da população 
brasileira e sua retratação nos folhetins eletrônicos, faz-se notável a significância de uma pesquisa que tente entender a forma como se dá essa representação, e contribuir, assim, com as pesquisas que têm sido realizadas sobre o assunto e sobre telenovela, de um modo geral. É uma forma também de colaborar para um debate sobre o tratamento dispensado ao assunto classe no Brasil.

Sabe-se que as classes sociais foram relegadas a segundo plano nas pesquisas acadêmicas, que tendem, recentemente, a ressaltar a pós-modernidade (MURDOCK, 2009), o que pode ser encarado como um reflexo do capitalismo atual. Assim sendo, o reavivamento das classes dentro da telenovela e no debate midiático pode ser considerado como um momento histórico digno de atenção.

Ademais, de acordo com pesquisadores da área (RONSINI, 2012), existem poucos estudos que explorem o tema classes sociais e desigualdades na telenovela. Ainda assim, a maioria das pesquisas por nós levantadas são estudos de recepção. Mais um motivo para que o assunto seja mais explorado academicamente e, sobretudo, do ponto de vista discursivo, por um prisma sócio-histórico e dialético, que analise o discurso midiático tanto pelo seu caráter de reprodutor de hegemonias como por sua capacidade de inovação.

Com esse intuito esta dissertação foi construída e está dividida em três capítulos, mais as considerações finais. O primeiro capítulo traz um breve levantamento histórico da telenovela; a exposição do conceito de midiatização e o seu uso neste trabalho; a contextualização da representação do que foi considerada a "nova classe C"; teorias sociológicas sobre o conceito de classe, que problematizam a nomenclatura "nova classe C"; o que dizem os estudos realizados sobre telenovela e classe social; e algumas considerações preliminares sobre a midiatização do consumo e do sentido de classe social nas telenovelas escolhidas.

No segundo capítulo, estão expostas explicações teóricas sucintas sobre o materialismo histórico e a dialética marxista; a inserção teórica da linguagem e do discurso nessas concepções marxistas; alguns aspectos das teorias discursivas de Mikhail Bakhtin, elementos da Análise do Discurso Francesa e da Análise do Discurso Crítica; e o protocolo de análise.

O terceiro capítulo exibe uma contextualização narrativa de Avenida Brasil e Cheias de Charme, e as análises das cenas selecionadas, realizadas de acordo com o protocolo de análise exposto no segundo capítulo, com o objetivo de averiguar as 
nuanças da midiatização do consumo e do sentido de classe nos dois folhetins eletrônicos.

As análises apontam para alguns resultados que são comentados com mais detalhes nas considerações finais, parte do trabalho na qual se pretende responder mais claramente as perguntas aqui propostas e oferecer, assim, um fechamento temporário para as inquietações que deram origem a essa pesquisa, além de abrir perspectivas futuras para a continuidade do trabalho. 


\section{TELENOVELA, MidiatizaÇÃo DO CONSUMO E DO SENTIDO DE CLASSE}

O objetivo deste capítulo, em um primeiro momento, é fazer um breve levantamento histórico e das principais características da telenovela, de modo a fomentar a abordagem das especificidades sociais e midiáticas nas quais foram produzidas as duas telenovelas que são foco deste trabalho - Avenida Brasil (2012) e Cheias de Charme (2012). Realizaremos também as considerações teóricas sobre o termo midiatização e como ele será usado neste estudo, ou seja, na sua interface com o consumo e com a construção do sentido de classe social.

O capítulo pretende discutir como as classes sociais têm sido representadas nas telenovelas, de acordo com uma amostra de pesquisas teóricas que exploram o tema, bem como trazer para a discussão teorias sobre o conceito de classes sociais e o momento econômico em que vivemos, a fim de problematizar a representação de classe na telenovela, os conceitos de "nova classe média" ou "nova classe C" e apontar para a análise da midiatização do sentido de classe social nessas circunstâncias, de maior poder de consumo.

\subsection{DO FOLHETIM À MIDIATIZAÇÃO, CONTEXTO REPRESENTACIONAL DA ASCENSÃO FINANCEIRA E DE CONSUMO}

De acordo com a pesquisadora Marlyse Meyer (1996), o folhetim nasceu na França na década de 1830, concebido pelo jornalista Émile de Girardin. O surgimento do novo gênero está estreitamente ligado com a necessidade mercadológica de democratizar o jornal, numa época em que a burguesia havia se consolidado no país e não era mais possível manter a imprensa como um privilégio daqueles que poderiam pagar por sua assinatura.

Segundo o teórico Jesús Martín-Barbero (2009), são as demandas populares e o desenvolvimento das tecnologias de impressão que vão fazer das narrativas um ponto de partida da produção massiva e trazer o folhetim como o primeiro tipo de texto escrito no formato popular de massa. 
Fenômeno cultural muito mais que literário, o folhetim conforma um espaço privilegiado para estudar a emergência não só de um meio de comunicação dirigido às massas, mas também de um novo modo de comunicação entre as classes. (MARTÍN-BARBERO, 2009, p. 176).

No início, folhetim designava o rodapé da primeira página do jornal, um espaço vazio destinado ao entretenimento e variedades. Tudo o que não era admitido no corpo do jornal podia ser publicado nessa área. Foi em 1836, que os donos dos jornais parisienses La Presse e Le Siècle introduziram, entre outras modificações, a publicação de narrativas por novelistas, que em pouco tempo ocuparam todo o espaço do folhetim (MARTÍN-BARBERO, 2009).

O autor aclara que os folhetins serviam como um testemunho - por meio de uma voz sentimental, moralista e até reacionária - do submundo urbano, com temáticas que exploravam a violência, a penitenciária, o hospício, a casa de prostituição, a miséria operária, a condição feminina desfavorável, o divórcio, o adultério, o aborto, entre outros problemas sociais.

“O universo operário que aí aparece é o de um proletariado sem consciência de classe - mas quantos romances tinham, antes, tematizado esse universo da miséria, do medo e da luta pela sobrevivência?” (MARTIN-BARBERO, 2009, p.192).

Outro fator importante levantado por Martin-Barbero (2009) é a característica de compensação da narrativa folhetinesca. Para realizar essa abordagem, o autor cita os estudos dos pensadores Antônio Gramsci (1977) e Umberto Eco (1970). O primeiro, ao invés de ir do texto para o autor, faz um caminho de análise que vai das classes subalternas para o texto, com questionamentos como o porquê do sucesso popular do folhetim.

De maneira similar, Eco (1970) se concentra em verificar os mecanismos que articulam ideologia e enredo, reconhecimento e indústria. O estudo revela que a narrativa entra em acordo com as expectativas do leitor. Há a junção entre intriga e moral, onde a consolação é produzida numa dinâmica de provocação-pacificação. Assim, o folhetim aponta e denuncia contradições sociais, mas ao mesmo tempo trata de resolvê-las para devolver a paz ao leitor, já que as soluções correspondem àquilo que ele espera (MARTIN-BARBERO, 2009).

De acordo com a dialética escritura e leitura como dispositivo-chave para entender como o mundo do leitor é incorporado ao processo de escritura, MartínBarbero (2009) categoriza quatro níveis compostos por dispositivos que marcam o universo popular e massivo do folhetim. O primeiro nível é o dos dispositivos de 
composição tipográfica (caracterizada por letras grandes, claras e espacejadas); o segundo nível apresenta os dispositivos de fragmentação, que tornam a leitura leve e espaçada por dias ou semanas; no terceiro nível estão os dispositivos de sedução, divididos em duração e suspense; e no quarto nível se situam os dispositivos de reconhecimento, que produzem a identificação do mundo do leitor popular com o mundo narrado.

[...] o folhetim se dirige às mesmas pessoas sobre as quais discorre. Isto ocorre de modo mais claro em seus primeiros tempos, mas não deixa de ocorrer depois. E o faz antes de mais nada mediante a intervenção de um novo tipo de herói que já não se move no espaço do sobrenatural, mas sim no espaço do real-possível. (MARTíNBARBERO, 2009, p. 189-190).

Quando o teórico aborda os primeiros tempos do folhetim, está se referindo à época marcada pelas histórias de Alexandre Dumas e Eugene Sue, por exemplo, cuja obra Os Mistérios de Paris retratou uma Paris subterrânea, de miséria operária e de criminosos. Meyer (1996) e Martin-Barbero (2009) apontam três fases do folhetim na França. A primeira diz respeito às histórias de mistérios e vinganças, nas quais se insere o romantismo social, de 1836 a 1850; o segundo período enfrentou a concorrência com os fait divers (relatos romanceados do cotidiano) e traz histórias de aventuras e intrigas, entre 1851 e 1871; já a terceira fase é caracterizada por uma posição mais reacionária, trata-se do momento mais sentimental, de valorização dos finais felizes, que foi de 1871 a 1914.

Meyer aclara que o folhetim da terceira fase é a base para o folhetim televisivo, “[...] o folhetim francês da terceira fase também é a grande matriz do pejorativo e indispensável recurso da grande narrativa de massa, tão inseparável da televisão como ele próprio foi do jornal [...]" (MEYER, 1996, p. 234). Eles retratam os costumes parisienses e os dramas cotidianos. Também retomam os temas romanescos, exaltam as virtudes domésticas e, ao mesmo tempo, trazem realismo ao enfatizar os dramas da vida.

Meyer (1996, p. 218) explica que esses folhetins ganharam alcunhas do tipo "romance dos crimes do amor", "romance da vítima", do "desgraça pouca é bobagem". As narrativas do romance da vítima distinguem-se pelo fim do "herói", o surgimento da "vítima" que respeita as convenções sociais e a transformação do grande vilão em um sedutor barato. 
A autora nos levanta um paradoxo pertinente do folhetim de terceira fase: ele é considerado popular e burguês ao mesmo tempo, pois propõe modelos burgueses de aspiração da vida. O romance popular retratava frequentemente a nobreza e a burguesia triunfante, “[...] vistas pelo duplo prisma da ideologia desta e do deslumbramento da pequena classe média e das classes populares.” (MEYER, 1996, p. 223).

Conforme explana a estudiosa, esse folhetim foi reproduzido no cinema, nos cineromances, nas fotonovelas, nas novelas de rádio e alcançou a sua descendente mais famosa no Brasil, a telenovela, a qual trouxe os sinais da aspiração pelo modelo burguês. "O sonho de Paris substituído pelos sonhos da Zona Sul do Rio de Janeiro ou os Jardins de São Paulo” (MEYER, 1996, p. 388).

De modo similar, a pesquisadora Esther Hamburger (1998) argumenta que as telenovelas difundem por todo o país o universo glamouroso de consumo das classes médias urbanas, entre outros aspectos, por meio do consumo de últimos lançamentos eletrônicos, de decoração e vestuário. Ela frisa que neste mundo da ficção, a desigualdade social se resolve em geral pela ascensão social, muitas vezes por meio do casamento.

Hamburger (1998) relata que os folhetins eletrônicos surgiram praticamente junto com a televisão no Brasil, veículo que assumiu grande importância na cultura brasileira. Sua relevância é perceptível no recorde de vendas de aparelhos televisores, na presença de diversos aparelhos por domicílio e nas inúmeras antenas parabólicas instaladas em muitos telhados de casas em comunidades carentes, por exemplo.

Desde o surgimento da primeira emissora brasileira em 1950, a TV Tupi de Assis Chateaubriand, a televisão no Brasil vem chamando a atenção de pesquisadores. Em 1970, a indústria de comunicação eletrônica se consolida no Brasil; na década de 1980 apenas $23 \%$ da programação brasileira era importada, quando somente alguns países desenvolvidos apresentavam índices baixos semelhantes; e na década de 1990, o Brasil já era o quarto país em número de aparelhos televisivos. Além disso, a televisão brasileira inverteu a direção dos circuitos internacionais de importação de mídia ao exportar telenovelas para países de todo o mundo (HAMBURGER, 1998).

De acordo com a pesquisadora, no início, as telenovelas eram produzidas por indústrias norte-americanas de artigos de limpeza e higiene, como a Colgate-Palmolive e a Gessy Lever, e o público-alvo era a mulher dona de casa. Entretanto, com o passar dos anos o gênero cresceu, dominou o horário nobre da televisão no Brasil e expandiu o seu público (HAMBURGER, 1998). 
A história da telenovela no Brasil, segundo a estudiosa Maria Lília Junqueira (2009), pode ser resumida em três fases: a primeira é o período de 1963 a 1970, marcado pelo surgimento da telenovela diária, pela produção orientada para o mercado e pela censura federal; a segunda fase está na década de 1980, que presenciou o fortalecimento da televisão no país, o crescimento da Rede Globo e enfraquecimento da censura; a terceira fase se iniciou em 1990 e vai até os dias de hoje, marcada pela interatividade, pelos hibridismos de forma e linguagem.

É importante frisar que em 1968, a telenovela Beto Rockfeller, transmitida na Tupi, representou um marco na teledramaturgia brasileira por criar uma nova linguagem nas tramas. De acordo com a pesquisadora Cristina Mungioli (2010) é a partir de Beto Rockfeller, com a mescla de realidade e ficção, que as discussões acerca dos problemas sociais vividos no Brasil estão presentes nas telenovelas. Passou-se a implantar mais realismo às tramas brasileiras, com uso de linguagem coloquial, ênfase em cenários contemporâneos e brasileiros e gravações externas (HAMBURGER, 1998).

Assim, a telenovela brasileira diferenciou-se das produções realizadas em outros países da América Latina, devido à sua carga de realismo. Balogh (2002) afirma que o melodrama brasileiro se tornou cada vez menos "lacrimogêneo" em comparação com o melodrama mexicano.

Segundo Hamburger (1998), essa característica possibilitou o crescimento do potencial comercial da telenovela.

\footnotetext{
Essa opção por uma definição clara no tempo e no espaço - a conjuntura contemporânea situada no âmbito da nação - potencializa a vocação da televisão para transmitir uma sensação de que os espectadores estão conectados com o mundo ao seu redor e acena a possibilidade concreta da inclusão por meio do consumo. (HAMBURGER, 1998, p. 467).
}

É recorrente o lançamento de moda pela telenovela, como a personagem Porcina (interpretada por Regina Duarte) de Roque Santeiro (1985 e 1986) e os clubes das mulheres, especializados em strip-tease na década de 1990, da trama De Corpo e Alma (1992), por exemplo (HAMBURGER, 1998).

Conforme pontua a estudiosa Heloisa Buarque de Almeida (2003), a telenovela pode ser uma vitrine de produtos e de estilos de vida associados aos bens de consumo. As tramas televisuais mostram como as personagens se vestem, se comportam e consomem bens e serviços, o que significa uma oportunidade rentável para empresas e marcas. 
Almeida (2003) atenta ainda para o fato de que as telenovelas funcionam de modo semelhante aos anúncios publicitários, com a vantagem de ter mais tempo e espaço para trabalhar o universo do consumo. Além de demonstrar didaticamente o uso de certos bens, ela permite uma identificação entre o produto e o usuário ideal dele.

Além disso, é possível dizer que o "realismo" peculiar da produção brasileira, por sua definição clara no tempo e no espaço da nação, permite a representação do que seria a sociedade brasileira e suas classes sociais, mas que não necessariamente condiz com a realidade do país. De acordo com Hamburger (1998), a telenovela representa o cotidiano de uma sociedade mais rica e mais branca que a brasileira, mas que acaba sendo reconhecida como se fosse a própria sociedade brasileira.

Do folhetim à telenovela, tem-se, assim, a valorização da individualidade e do subjetivismo voltado à satisfação pessoal nos desejos de consumo, o que demonstra a conexão entre a lógica do capital e as representações midiáticas sobre o consumo e classe social, aspecto esse que já havia sido sinalizado por Campbell em sua obra $A$ ética romântica e o espírito do consumismo moderno (2001).

Também é oportuno salientar, neste momento, dado o potencial da telenovela no Brasil, o papel cada vez maior que a mídia como um todo vem assumindo na sociedade e em seus processos de interação, devido às transformações sociais e aos avanços tecnológicos.

Essa posição da mídia em nosso cotidiano fez emergir nas pesquisas em comunicação, nos últimos anos, a necessidade de se encontrar um termo comum capaz de abranger as transformações que vêm ocorrendo devido à presença midiática. $\mathrm{O}$ termo que está sendo utilizado para isso é midiatização (COULDRY; HEPP, 2013).

De um modo amplo, “[...] midiatização é um conceito usado para analisar criticamente a inter-relação entre mudanças na mídia e comunicações por um lado, e mudanças na cultura e sociedade, por outro" (COULDRY; HEPP, 2013, p. 197). ${ }^{1}$

O conceito é importante para a nossa discussão, uma vez que a telenovela assume um papel privilegiado na construção de um imaginário social brasileiro, inclusive em relação ao sentido de classes sociais no Brasil.

De acordo com a pesquisadora Maria Immacolata Vassalo Lopes (2009), a telenovela é uma figura central da cultura e da identidade do Brasil e é o produto de maior popularidade e lucratividade da televisão brasileira, além de colocar no cotidiano

\footnotetext{
${ }^{1}$ Tradução nossa. "[...] mediatization is a concept used to analyze critically the interrelation between changes in media and communications on the one hand, and changes in culture and society on the other."
} 
discussões sociais importantes, como o casamento inter-racial, problemas de violência, dificuldades enfrentadas por portadores de necessidades especiais, bulimia juvenil, dentre outros.

Ademais, o folhetim eletrônico se apropria do cotidiano e toma forma de memória histórica da sociedade brasileira (MOTTER, 2000-2001). De acordo com pesquisa realizada por Motter (2003), existe relação entre o cotidiano vivido e o cotidiano construído pelo universo ficcional.

Lopes (2004) também traz um importante estudo sobre a globalização e suas ambivalências na narrativa televisiva. Para a autora, a telenovela possui um valor estratégico na criação e consolidação de novas identidades culturais, já que possui o caráter de narrativa popular sobre a nação e configura-se como o local onde a nação é representada e imaginada.

Essas características demonstram o poder midiático da telenovela no Brasil e a pertinência de abordar o conceito de midiatização para estudar os seus processos.

$\mathrm{Na}$ verdade, existem diferentes vertentes de pesquisa e formas de conceber a midiatização. Alguns pesquisadores a entendem como um processo longo que tem acompanhado toda a história da humanidade; enquanto outros usam o termo para descrever o crescimento da relevância social e cultural da mídia desde a emergência da mídia de massa, como a imprensa, o rádio, o cinema e a televisão (COULDRY; HEPP, 2013).

Além disso, os autores identificam duas correntes de estudo sobre a midiatização: a institucionalista e a tradição social-construtivista. Elas coexistem e estão se tornando cada vez mais convergentes. A primeira, que vem principalmente dos estudos do jornalismo e da comunicação política, enxerga a mídia como uma instituição mais ou menos independente com uma lógica própria, e entende a midiatização como uma adaptação de diferentes campos sociais às regras midiáticas institucionalizadas. (COULDRY; HEPP, 2013).

A vertente social-construtivista, por sua vez, entende o conceito como um processo de construção comunicativa da realidade social e cultural. Trata-se de uma concepção mais aberta que a lógica da mídia, pois enfatiza a complexidade da mídia como instituição e tecnologia (COULDRY; HEPP, 2013).

O pesquisador brasileiro José Luiz Braga faz parte da tradição socialconstrutivista. Para o autor, estamos vivendo uma transição entre um processo interacional de referência da escrita para um processo interacional de referência 
midiatizado de base tecnológica. Um processo interacional de referência se refere não só à hegemonia e preferência por um modo de interação (o escrito, por exemplo), mas também considera que a sociedade é organizada através desse modo interativo (BRAGA, 2006).

De acordo com o autor, a midiatização pode ser relacionada a processos específicos que passam a se desenvolver de acordo com a mídia, como política, entretenimento, consumo, e também pode estar relacionada a um nível maior, no sentido da própria sociedade estar midiatizada (BRAGA, 2006).

Para um maior detalhamento do tema midiatização institucionalista tomaremos o levantamento de dois tipos de midiatização, a saber: a direta e a indireta. A direta é quando uma determinada atividade passa a ser executada de uma forma diferente devido à mídia, como, por exemplo, jogar xadrez ou fazer transações bancárias pela internet. A forma indireta se refere à influência cada vez maior da mídia em uma determinada atividade, mas que não afeta diretamente o modo como as pessoas executam uma tarefa; trata-se de uma influência mais sutil. (HJARVARD, 2012).

Um exemplo mais complicado de midiatização indireta é o desenvolvimento do discurso intertextual entre os meios de comunicação e outras instituições da sociedade. Por exemplo, o conhecimento dos brasileiros sobre os EUA também se deve às narrativas dos meios de comunicação (fato ou ficção) sobre o país; como consequência, as discussões políticas brasileiras sobre os EUA também estão entrelaçadas com representações midiáticas da cultura, dos costumes e da história norte-americanos. (HJARVARD, 2012, p. $67)$.

A forma indireta nos parece como hipótese a que mais se aproxima da midiatização dos sentidos dos consumos e das classes proporcionados pelas telenovelas, uma vez que podemos considerar o folhetim eletrônico como narrativa da nação (LOPES, 2004). Além disso, a midiatização do sentido de classe diz respeito a uma representação social da cultura brasileira que não interfere em modos específicos de realizar uma tarefa e sim faz parte do imaginário nacional.

É possível dizer também que a perspectiva de midiatização indireta se assemelha à visão macrossocial abordada por Braga (2006), segundo a qual a sociedade constrói a realidade social através de processos interacionais pelos quais os indivíduos, grupos e setores da sociedade se relacionam.

Outro ponto importante de ser abordado é o caráter de mudança que o termo midiatização traz. Os quatro estudiosos sobre o tema citados neste trabalho - Braga 
(2006), Hjarvard (2012), Couldry e Hepp (2013) - concordam nesse sentido. Hjarvard (2012) defende a posição de que a midiatização não é um processo universal, mas sim uma tendência que se acelerou nos últimos anos do século XX nas sociedades modernas e desenvolvidas. O autor atrela essa tendência com as transformações da globalização, por isso é um processo que se dá de forma diferente em cada região do mundo.

Braga (2006), ao abordar a midiatização como um processo incompleto transparece o caráter de mudança do fenômeno, que está vinculado com as demandas e transformações tecnológicas dos meios de comunicação e às novas formas de interações sociais.

Couldry e Hepp (2013) também exprimem o aspecto de transformação embutido no conceito quando o opõe ao significado de mediação. Enquanto este último se refere ao processo de comunicação em geral, midiatização designa mudança. "Midiatização reflete como as consequências globais de múltiplos processos de mediação têm mudado com a emergência de diferentes tipos de mídia." (COULDRY; HEPP, 2013, p. 197). ${ }^{2}$

De acordo com Lopes (2004), os fenômenos de expansão das tecnologias de comunicação e a intensificação de migrações (reais e imaginadas) possibilitam a mobilidade e circulação de ideias e são cruciais neste novo cenário para a criação de novas identidades, pois possibilita também a circulação de universos simbólicos.

Histórias narradas pela televisão são, antes de tudo, importantes por seu significado cultural. Como bem o demonstra o filão de estudos internacionais, a ficção televisiva configura e oferece material preciso para entender a cultura e a sociedade de que é expressão. (LOPES, 2004, p, 125).

As tecnologias têm grande influência nos processos das telenovelas. Conforme evidencia Lopes (2004), as inovações tecnológicas possibilitaram a vocação transacional da televisão, favorecendo a circulação sem fronteiras de produtos, formatos, personagens e temas.

De acordo com a pesquisadora Márcia Tondato (2012) o gênero ficcional, e o melodrama dentro dele, assume posição importante no processo de internacionalização cultural. Segundo a autora, a telenovela tem o papel de tornar comuns novas dinâmicas e modos sociais, trazendo para o cotidiano dos telespectadores práticas que só eram acessíveis em outros produtos culturais, como os livros. Essas práticas são constituídas

\footnotetext{
2 Tradução nossa. "Mediatization reflects how the overall consequences of multiple processes of mediation have changed with the emergence of different kinds of media."
} 
também pela exposição de produtos que passam a ser incorporados no dia a dia por meio do consumo.

O trabalho realizado pelos pesquisadores Eneus Trindade e Clotilde Perez (2014) traz contribuições importantes sobre o tema, com enfoque na midiatização no consumo. Os autores fazem uma abordagem conceitual que reflete sobre as dimensões teóricas da presença da mídia na formação de hábitos e atitudes de consumo e na construção de vínculos de sentidos entre as expressões da marca/produtos/serviços e seus consumidores.

De acordo com os autores, os estudos da área não têm discutido a presença midiática do consumo na perspectiva tratada no artigo em questão. O que tem sido feito, pelo menos no Brasil, é abordar o consumo midiático, que se aproxima mais dos estudos de recepção. Enquanto, de forma diversa, os estudos do consumo midiatizado buscam "[...] compreender as formas de presença e consequências das atuações do sistema publicitário (via marcas de empresas, produtos e serviços)" (TRINDADE; PEREZ, 2013, p. 3).

Ainda, explicam que a comunicação de marcas por meio do sistema publicitário gera práticas referencias culturais de consumo. Desse modo, o ritual de consumo, do ponto de vista comunicacional, é percebido como “[...] dispositivo articulador dos sentidos dos produtos/marcas na vida das pessoas, portanto, a presença do sistema publicitário é constitutiva nesta relação de consumo." (TRINDADE; PEREZ, 2013, p. $5)$.

Desse modo, de acordo com as teorias expostas, entendemos que o termo midiatização aponta para a crescente importância da mídia em nosso cotidiano, possibilitada pelas transformações tecnológicas e sociais, que conferem a ela a capacidade de influência em processos sociais significativos.

Trataremos a midiatização do consumo com foco nas representações de classes sociais no Brasil pela telenovela para tentar levantar, teoricamente, as formas de presença dessas representações nas discussões sociais. Nosso foco está no que vem sendo entendida como a representação da "nova classe C" ou "nova classe média" brasileira, expressão lançada pelo economista Marcelo Neri (2010).

De acordo com o projeto Vozes da Classe Média (2012) da Secretaria de Assuntos Estratégicos (SAE) do Governo Federal em parceria com Caixa Econômica Federal (CEF) e o Programa das Nações Unidas para o Desenvolvimento (PNUD), nos últimos 10 anos, 37 milhões de pessoas entraram na classe média - que passou de $38 \%$ da 
população, em 2002, para 53\%, em 2012, somando hoje mais de 100 milhões de brasileiros. Ainda segundo o projeto, dos 37 milhões de pessoas a mais na classe média, oito milhões resultam do crescimento natural da população (diferença entre a taxa de natalidade e a taxa de mortalidade de um determinado local ou país) e 29 milhões se devem ao processo de ascensão social (VOZES DA CLASSE MÉDIA 2012, p.13).

Essa ascensão tem influenciado o mundo da ficção televisiva brasileira. As pesquisadoras Lopes e Mungioli (2012, p. 129) utilizam o termo "drama do reconhecimento" (emprestado do autor Martín-Barbero que a utiliza para o melodrama) para abordar o desejo da "nova classe média" por representação na mídia, de um modo geral, e especialmente na televisão e na telenovela. Na visão das autoras, as novas experiências de representação são desafios para a ficção.

A tomada de decisão por parte das redes em tornar a programação da televisão mais popular não deve ser entendida como simplificação ou produção de conteúdos mais apelativos, mas antes como um processo bastante difícil de incluir novas vozes ou demandas nessa programação. (LOPES; MUNGIOLI, 2012, p. 130).

Tal movimento é evidente nas ficções de diversos horários da rede, por exemplo, as protagonistas empregadas domésticas da telenovela Cheias de Charme (2012), de Filipe Miguez e Izabel de Oliveira, transmitida às 19 horas; e as famílias ficcionais que ascendem financeiramente na telenovela Avenida Brasil (2012), de João Emanuel Carneiro, transmitida às 21 horas.

Várias matérias foram divulgadas na imprensa, na época, que atestaram o sucesso das duas tramas e realçaram a representação da "nova classe C" nas narrativas. Citaremos, a seguir, alguns exemplos.

Na edição da Revista Veja do dia 25 de abril de 2012, uma nota afirma que com as estreias das tramas Avenida Brasil e Cheias de Charme, a Globo apontou como nunca antes para a "classe C". A nota declara que, de acordo com levantamentos do site da própria revista, 93\% dos personagens de Avenida Brasil eram da "classe C" e ocupavam os núcleos centrais da trama, e não apenas os secundários, como era comum nas telenovelas (CLASSE C NO HORÁRIO NOBRE, 2012).

O jornal O Estado de S. Paulo, no dia 18 de abril de 2012, publicou matéria com o título "UM BRINDE À CLASSE C". A reportagem alega que a trama Cheias de Charme cultua o papel que as empregadas domésticas têm hoje na economia nacional, pois são mulheres mais esclarecidas e profissionais cada vez mais raras. 
"É um painel disposto a seduzir a emergente classe $C$, não no sentido de lhe mastigar todo o script, como quem subestima seu alcance intelectual, mas de celebrar justamente seu crescimento.” (PADIGLIONE, 2012, p. 5). Porém, a matéria também chama a atenção para o fato de o mundo mostrado na trama ainda ser muito glamourizado.

Outra matéria da Revista Veja intitulada “Será o apocalipse?" aborda a fala alta e estridente dos personagens de Avenida Brasil, fazendo referências a uma representação mais popular, evidente no subtítulo "GOGÓS SUBURBANOS” (MARTHE, 2012b).

De acordo com o autor João Emanuel Carneiro, em entrevista à Revista Veja na edição do dia 4 de julho de 2012, a elite tradicional perdeu seu charme. Na visão dele, “As pessoas agora querem saber é da vida dos jogadores de futebol, cantores sertanejos e atores da TV - aquele pessoal de origem humilde que enriqueceu e mora em condomínio na Barra da Tijuca”. (MARTHE, 2012a, p.17).

Apesar de o autor afirmar que a ideia de retratar o subúrbio carioca não se deu por oportunismo pela ascensão de uma "classe C" nem por encomenda da Rede Globo, demonstra que o personagem Tufão e sua família são exemplos dos pobres-ricos no Brasil, pessoas simples que ganharam dinheiro, mas que continuam com o jeito suburbano. Carneiro revela que os brasileiros da "classe C" se identificam com a representação dessa nova elite, "[...] mas o dado novo e interessante é que as classes A e B foram igualmente arrebatadas pelo Tufão e sua parentada ruidosa" (MARTHE, 2012a, p. 20).

De acordo com o Anuário Obitel de 2013, (LOPES; GOMEZ, 2013), dos dez programas de ficção brasileiros mais vistos no país no ano de 2012, a telenovela Fina Estampa ocupou o primeiro lugar, Avenida Brasil o segundo e Cheias de Charme o terceiro. Segundo matéria publicada no caderno Cidades do jornal $O$ Estado de $S$. Paulo, no dia 20 de outubro de 2012, no saldo final de audiência Avenida Brasil empatou com Fina Estampa, sua antecessora, com 39 pontos de média. A reportagem explica que Fina Estampa teve uma audiência mais equilibrada do começo ao fim, enquanto Avenida Brasil atingiu mais de 40 pontos depois do capítulo 100 (PADIGLIONE; DEODORO, 2012, p. 6).

O fato é que as duas telenovelas que são foco neste trabalho - Avenida Brasil e Cheias de Charme - foram sucesso de audiência. Inclusive, a trama das 19 horas Cheias de Charme ficou à frente da telenovela das 21 horas Salve Jorge na lista dos dez títulos mais vistos (LOPES; GOMEZ, 2013). 
A telenovela Avenida Brasil, especificamente, é apontada pelas pesquisadoras Maria Immacolata Vassallo de Lopes e Maria Cristina Palma Mungioli (2013) como um grande destaque de 2012. A trama é mencionada como um fenômeno midiático, um dos grandes acontecimentos da indústria televisiva brasileira em 2012, um marco na teledramaturgia e uma "narrativa da nação".

As autoras contam que Avenida Brasil se destacou, entre outros motivos, no que se refere ao engajamento da audiência com a trama, perceptível no volume de conteúdos (de produtores da trama e usuários da internet) sobre a ficção que foi propagado nas redes sociais (LOPES; MUNGIOLI, 2013).

A trama ganhou destaque não só na imprensa nacional, mas também em veículos internacionais, como Forbes, The Guardian e Le Figaro que queriam entender "o fenômeno Avenida Brasil" (LOPES; MUNGIOLI, 2013, p.154).

Além disso, o último capítulo do folhetim causou um aumento de mais de $5 \%$ na energia no Brasil e provocou alterações na agenda da presidente da República. Esse cenário, segundo considerações das pesquisadoras, faz do fenômeno Avenida Brasil um “popular media event” (LOPES; MUNGIOLI, 2013, p. 155).

As autoras argumentam que Avenida Brasil foi uma espécie de divisor de águas nas telenovelas, como o que ocorreu com Beto Rockfeller (1968) ao criar um novo paradigma de telenovela com uma nova forma de narrar e representar o Brasil.

[...] Avenida Brasil abordou temas e problemas já vistos em outras telenovelas, mas o fez incorporando e traduzindo de maneira magistral o esprit du temps de um país no qual ocorrem grandes mudanças sociais que criam espaços simbólicos nos quais reverberam os discursos de novos protagonistas. Entre as mudanças sociais está a ascensão de milhões de brasileiros à "nova classe C". (LOPES; MUNGIOLI, 2013, p. 156-157).

A ascensão foi mostrada, segundo as estudiosas, a partir das enunciações dos personagens do fictício subúrbio carioca, chamado Divino, onde viviam quase todos os personagens da trama e representava um cenário protagonista da história que "[...] aliado aos discursos das personagens, constituía um sistema retórico estruturado com um estilo de uso, maneira de ser e maneira de fazer [...].” (LOPES; MUNGIOLI, 2013, p. 157).

De modo similar, Cheias de Charme mostra a ascensão por meio das três empregadas domésticas protagonistas. A trama também representa outro aspecto importante da sociedade brasileira, que é a valorização do emprego doméstico no país. 
Apesar de anteceder a nova lei trabalhista para as domésticas que entrou em vigor em abril de 2013, Cheias de Charme captou o movimento que já vinha ocorrendo no país. Conhecida como PEC das domésticas, a nova regulamentação aumenta os direitos dos trabalhadores da área, como jornada máxima de 44 horas semanais e de até 8 horas diárias, pagamento de hora extra, adicional noturno, seguro-desemprego e Fundo de Garantia do Tempo de Serviço (FGTS) (PORTAL BRASIL DO GOVERNO FEDERAL, 2013).

Desse modo, como foi demonstrado, temos nas duas tramas - Avenida Brasil e Cheias de Charme - material discursivo rico para a análise da midiatização do consumo e do sentido de classe, principalmente no que tange às especificidades atuais que fizeram emergir os conceitos "nova classe C" ou "nova classe média". Assim, cabe a este trabalho discutir as questões que circundam a forma como se dá a construção midiática do consumo e do sentido de classe social nessas duas tramas.

Para tanto, faz-se pertinente problematizar o termo "nova classe média" com o aporte de teorias sociológicas que abordam o conceito classes sociais, além de levantar a contribuição de pesquisas na área de comunicação que se preocupam com a temática telenovela e classes.

\subsection{CONSIDERAÇÕES TEÓRICAS SOBRE CLASSE SOCIAL E ESTUDOS SOBRE SUA REPRESENTAÇÃO NA TELENOVELA}

Na obra Os Batalhadores Brasileiros: nova classe média ou nova classe trabalhadora? (2012), o sociólogo brasileiro Jessé Souza argumenta que os brasileiros que entraram para o mercado de consumo nos últimos anos não fazem parte de uma "nova classe média", e sim de uma nova classe trabalhadora, denominada por ele como batalhadores, situada entre a classe média e alta e ao que ele chama provocativamente de "ralé" para se referir aos excluídos.

Na visão do sociólogo o que caracteriza toda classe trabalhadora é sua inclusão subordinada no processo de acumulação do capitalismo em todas as suas fases históricas, como o capitalismo financeiro contemporâneo dito flexível (SOUZA, 2012).

O economista Marcio Pochmann (2012) também compartilha da visão de que não há uma nova classe média. A maior parte da população emergente, na visão do autor, se 
associa às características gerais das classes populares, que ao elevar o rendimento ampliam imediatamente o padrão de consumo. "O adicional de ocupados na base da pirâmide social reforçou o contingente da classe trabalhadora, equivocadamente identificada como uma nova classe média." (POCHMANN, 2012, p. 11).

Dentre as transformações que acarretaram o aumento da base da pirâmide social está a expansão do setor terciário na produção nacional que se refletiu na composição da força de trabalho no país. Além do setor terciário, ocupações na construção civil e nas indústrias extrativas também tiveram importância, em menor escala, na expansão dos postos de trabalho na década de 2000 (POCHMANN, 2012).

$\mathrm{O}$ autor argumenta que a maioria dos postos de trabalho gerados concentra-se na base da pirâmide social, já que $95 \%$ das vagas abertas tinham remuneração de até 1,5 salário mínimo, fazendo com que a população com esse salário crescesse na década de 2000.

Com isso, uma parcela considerável da força de trabalho conseguiu superar a condição de pobreza, transitando para o nível inferior da estrutura ocupacional de baixa remuneração, embora não seja mais pobre, tampouco pode ser considerada classe média. (POCHMANN, 2012, p. 20)

De acordo com Jessé Souza, a classe média se diferencia por se reproduzir pela transmissão de capital cultural de forma emocional e afetiva no seio familiar, como a criança que vê o pai lendo jornal, a mãe lendo romance e o tio falando inglês fluente, por exemplo. "O processo de identificação afetiva [...] se dá de modo natural e 'préreflexivo"” (SOUZA, 2012, p. 24). Trata-se de um processo que envolve vantagem na competição social em relação às classes desfavorecidas, como a trabalhadora e a "ralé".

$\mathrm{Na}$ visão do autor, a ideia de uma nova classe média faz parte de um discurso pertencente àqueles que vendem o mundo neoliberal existente como o melhor e acreditam em um Brasil que está entrando para o primeiro mundo, "[...] onde as "classes médias', e não os pobres, os trabalhadores e os excluídos, como na periferia do capitalismo, formam o fundamento da estrutura social" (SOUZA, 2012, p.20).

A pesquisa realizada pelo autor revela que as formulações que classificam os emergentes como "classe média" são meias-verdades, pois não consideram os conflitos e as contradições dos acontecimentos reais e acabam, assim, por reforçar o domínio do novo tipo de capitalismo no Brasil. 
O que o liberalismo economicista dominante faz é "dizer" que existem classes e negar, no mesmo movimento, a sua existência ao vincular classe à renda. É isso que faz com que os liberais digam que os "emergentes" são uma "nova classe média" por ser um estrato com relativo poder de consumo. O marxismo enrijecido não percebe também as novas realidades de classe porque as vinculam ao lugar econômico na produção e, engano mais importante e decisivo ainda, a uma "consciência de classe" que seria produto desse lugar econômico. (SOUZA, 2012, p. 22).

Desse modo, tanto o economicismo liberal, quanto a esquerda envelhecida, na visão do autor, percebem a realidade das classes sociais apenas pelo âmbito econômico. Souza (2012), ao contrário, defende que a reprodução de classes sociais depende da transferência de valores imateriais.

Cabe-nos, neste instante, levantar o conceito de classe social para o pensador Karl Marx para entendermos o posicionamento de Souza (2012) quando aborda a face economicista do marxismo e o vínculo marxista entre classe e consciência de classe.

Em $O$ Capital, originalmente publicado na Alemanha em 1867, Marx concebe a divisão de classes de acordo com a lógica capitalista que reproduz as diferenças entre os detentores dos bens e os assalariados de forma contínua, por meio da exploração do mesmo pelos donos do capital, com a instauração da mais-valia ${ }^{3}$. Assim, a jornada de trabalho torna-se relativa de acordo com a visão do dono da produção "O capital é trabalho morto, que, como um vampiro, vive apenas da sucção de trabalho vivo, e vive tanto mais quanto mais trabalho vivo suga" (MARX, 1867, 2013, p. 307).

No Manifesto Comunista, publicado pela primeira vez em 1848, Marx e Engels argumentam que a história de todas as sociedades de todos os tempos é a história da luta de classes e que a sociedade burguesa moderna é caracterizada por ter simplificado os antagonismos de classes ao se dividir cada vez mais em dois campos opostos: a burguesia e o proletariado. (MARX; ENGELS, 1848, 1999).

Os pensadores abordam as transformações do sistema de produção feudal para o sistema burguês vigente em sua época e chega a mencionar a existência de outras classes que se pulverizaram na oposição entre as duas classes mencionadas.

As camadas inferiores da classe média de outrora, os pequenos industriais, pequenos comerciantes e pessoas que possuem rendas, artesãos e camponeses, caem nas fileiras do proletariado: uns porque

\footnotetext{
${ }^{3}$ Valor adicional de um produto, que supera a soma dos valores necessários para a sua produção, como os meios de produção e a força de trabalho. Esse valor a mais é possível devido ao fato do capitalista não pagar pelo valor total gerado pelo trabalho de seus funcionários. Ele se apropria do trabalho destes e lucra com isso.
} 
seus pequenos capitais, não lhes permitindo empregar os processos da grande indústria, sucumbiram na concorrência com os grandes capitais; outros porque sua habilidade profissional é depreciada pelos novos métodos de produção. Assim, o proletariado é recrutado em todas as classes da população. (MARX; ENGELS, 1848, 1999, p. 20)

Em sua abordagem sobre as diferentes fases do proletariado, Marx e Engels citam outras frações de classe que acabam por ser dissolvidas. Existe uma fase em que os proletariados não combatem os seus inimigos, mas os inimigos de seus inimigos, “[...] os restos da monarquia absoluta, os proprietários territoriais, os burgueses não industriais, os pequenos burgueses." (MARX; ENGELS, 1848, 1999, p. 21).

Mas, com o desenvolvimento da indústria o número de proletários aumenta e frações dessa antiga classe são precipitadas no proletariado ou têm sua existência ameaçada. Assim, os teóricos afirmam que as outras classes degeneram com o desenvolvimento da indústria, enquanto o proletariado é o seu produto mais autêntico (MARX; ENGELS, 1848,1999).

Os autores mencionam ainda o lumpen-proletariado, como "produto passivo da putrefação das camadas mais baixas da velha sociedade" (MARX; ENGELS, 1848,1999 , p. 24), cujas condições de vida não o permitem ser revolucionário como a classe proletária, embora possa ser arrastado por essa às vezes.

Em suma, todas as transformações acerca do sistema produtivo, comentadas por Marx e Engels no Manifesto Comunista $(1848,1999)$ apontam para a luta entre a classe proletária e a burguesia, como comentam os teóricos sobre a obra marxista.

De acordo com Murdock (2009), apesar da influência de Karl Marx por toda uma geração de pensadores, ele nunca forneceu uma definição clara sobre classe social, posto que identificava classe com posição econômica e a dividia entre os que possuíam as propriedades (terra, imóveis e fábricas, por exemplo) e aqueles que precisavam vender a sua força de trabalho para se sustentar.

$\mathrm{O}$ autor ainda frisa que o ponto fraco de Marx era a classe média. O pensador enxergava a polarização contínua da sociedade devido à crescente produção capitalista que vinha dividindo a sociedade entre aqueles que detêm o capital e os meios produtivos e os assalariados que não são donos de sua própria força de trabalho. (MURDOCK, 2009).

Rafael Grohmann (2013), em seu artigo sobre o conceito de classe no marxismo, afirma que nas obras de Marx o conceito de classe está mais presente de forma aplicada 
e não necessariamente como uma definição sistemática. Enquanto conceito, a noção de classe social é mais presente no marxismo e em suas diferentes correntes.

É pertinente destacar ainda cinco dimensões básicas de classe que são discutidas ao longo do trabalho de Marx. São elas: estrutura de classe, formação de classe, culturas de classe, consciência de classe e ação de classe (MURDOCK, 2009).

A estrutura de classe se refere à posição econômica marcada por aqueles que possuem o capital e aqueles que não possuem. A formação de classe se dá por meio do controle sobre o capital, que possibilita que a burguesia explore continuamente o proletariado, produzindo desigualdade estrutural. Assim, o controle do capital possibilita não só a posse, mas também um meio de exploração. Tem-se a divisão entre capital e trabalho (MURDOCK, 2009).

A cultura de classes se refere às características, sentimentos e maneiras de pensar de cada classe. Já a consciência de classe, Murdock (2009) pontua que nem sempre é clara, pois, muitas vezes, os subordinados se adaptam e não enxergam os capitalistas como inimigos. E a ação de classe é atribuída aos partidos socialistas, cuja função é promover a luta de classes para a emancipação da classe trabalhadora oprimida.

Souza (2006) não concorda com a conexão entre a classe social com a leitura marxista que assimila classe à consciência de classe. Essa concepção é enganosa para o autor, pois em sua visão existe uma inconsciência de classe, ou seja, há aspectos préreflexivos e semiconscientes na legitimação das diferenças sociais.

Assim, Jessé Souza defende o caráter simbólico na formação das classes sociais, de acordo com as contribuições do teórico Pierre Bourdieu (2007), cujas teorias chamaram a atenção para elementos como capital cultural e habitus de classe.

A classe social para este pensador não é definida por uma propriedade, nem por uma soma de tipos de propriedade, nem por uma cadeia de propriedades, mas pela estrutura das relações entre todas as propriedades que confere valor a cada uma delas e aos efeitos que essa relação exerce sobre as práticas (BOURDIEU, 2007).

$\mathrm{O}$ autor argumenta que as diferenças primárias de classe encontram sua origem no volume global do capital: capital econômico, capital cultural e capital social. Ao longo de seu texto, aborda três grandes classes, as classes superiores, as classes médias e as classes populares, no interior das quais há subdivisões por ocupação profissional (BOURDIEU, 2007).

Para o pensador, além das diferenças primárias, existem as diferenças secundárias, que são dissimuladas pelas primeiras e separam as frações de classe, no interior de cada 
uma das classes, por distribuição diferente do capital global. Por exemplo, há frações de classes tanto do nível superior quanto do nível médio, cuja reprodução depende do capital econômico, enquanto em outras frações a reprodução depende do capital cultural (BOURDIEU, 2007).

Assim,

As frações cuja reprodução depende do capital econômico, frequentemente herdado - no nível superior, industriais e grandes comerciantes; e, no médio, artesãos e pequenos comerciantes -, opõem-se às frações mais desprovidas (e claro, relativamente) de capital econômico e cuja reprodução depende, principalmente, do capital cultural - no nível superior, professores universitários e do secundário; e, no nível médio, professores primários. (BOURDIEU, 2007, p. 105).

Murdock (2009) argumenta que Bourdieu considera a estrutura de classe como um espaço multidimensional, no qual as classes são definidas pelo capital possuído, por sua composição e pela constituição e peso variáveis de sua propriedade ao longo do tempo.

O capital cultural é entendido como uma propriedade, também como processo de circulação e acumulação, assim como o capital financeiro, compreendendo também a disposição estética para a arte, possível apenas para aqueles cujo mundo é livre de urgências e preocupações com questões práticas (BOURDIEU, 2007).

A disposição cultural pode ser herdada, por meio de rotinas e reproduções de práticas na vida de um indivíduo e através de gerações. A educação formal é vista como herança para as crianças, que adquirem habilidades em manejar categorias abstratas e formais. Desse modo, o habitus, é formado pela correspondência entre o espaço das posições sociais e o espaço dos etilos de vida, das disposições. Os habitus delineiam as diferentes práticas sociais de diferentes grupos sociais, e exprimem as diferenças (BOURDIEU, 2007).

É pertinente comentar o gosto de classe abordado por Bourdieu, para quem, o gosto é um produto da cultura social e da educação; e a ideologia do gosto natural nega as evidências sociais e naturaliza as diferenças reais, convertendo em diferenças de natureza aquelas que são constituídas pelo modo de aquisição da cultura (ORTIZ, 1983).

Jessé Souza (2012) compartilha da visão do autor. De acordo com Souza, a naturalidade dos "bons comportamentos" passa a ser percebida como mérito individual, 
pelo esquecimento do processo da socialização familiar, que é peculiar a cada classe social específica. (2012, p. 48).

Desse modo, Souza explica que existe uma transferência de valores imateriais na reprodução da desigualdade social no país, uma vez que, além de capital econômico e capital cultural, existem precondições sociais, morais e culturais que permitem a apropriação desses capitais (SOUZA, 2006, 2012).

Para entender a naturalização e legitimação da desigualdade social no Brasil, o autor desconstrói paradigmas antigos que tentam explicá-la. São eles: o personalismo/patrimonialismo, o economicismo e o racialismo (SOUZA, 2006). O primeiro, que traz uma característica subjetivista, explica a desigualdade por meio de traços culturais brasileiros, compostos por um capital social de relações pessoais; visão presente nos trabalhos de Sérgio Buarque de Holanda (2002) e Roberto Da Matta (1997), por exemplo. O economismo, que é uma variação do primeiro, percebe a desigualdade brasileira como um problema econômico, enfatiza aspectos como renda e secundariza aspectos não econômicos, como a ausência de reconhecimento social e aprendizado familiar. Já o racialismo explica a desigualdade social por meio da cor/raça (SOUZA, 2006).

A partir disso, o autor assinala a necessidade de se entender como o capitalismo se justifica socialmente, pois a atividade econômica não é neutra, e aponta para o racionalismo religioso ocidental discutido por Max Weber (2005) - caracterizado pela disciplina, cálculo racional, controle do corpo e de suas emoções e necessidades - que passa a ter como suporte a lógica impessoal do mercado e do Estado (SOUZA, 2006).

Souza (2006) explica que o Ocidente faz uma oposição entre mente e corpo. O que está relacionado à mente seria digno e o que está relacionado ao corpo seria indigno. As profissões que utilizam apenas o corpo para o trabalho são desvalorizadas. Assim, forma-se um consenso compartilhado, um senso comum, uma dimensão préreflexiva, a respeito do valor dos indivíduos.

Com a queda do prestígio das justificações religiosas entra em cena o processo de transformação da economia.

A justificação moral do capitalismo passa a se vincular à noção de bem-estar geral definida como produto do progresso material. É, afinal, esse vínculo entre progresso material e bem-estar geral que está implícita na definição do PIB como símbolo máximo do progresso material e do bem-estar de uma "empresa" capitalista. (SOUZA, 2012, p. 28). 
O que é importante destacar, na visão deste trabalho, das explanações do sociólogo é que existe uma justificativa simbólica do capitalismo e uma legitimação semiconsciente, partilhada pelo senso comum, da reprodução da desigualdade social no país (SOUZA, 2012), bem como características imateriais de classe social que são herdadas por gerações, como explica Bourdieu (2007).

No entanto, acreditamos que a noção de classe social, em sua gênese, está relacionada com a atividade de trabalho e com a posição ocupada no modo de produção social, como defende o marxismo, ainda mais se considerarmos que a ideia de classe trabalhadora continua bastante viva no capitalismo vigente, sobretudo por trás do discurso da "nova classe média".

De acordo com Fígaro e Grohmann (2013, p. 10-11), um dos problemas de se tratar o conceito de classe social academicamente é o fato da maioria dos trabalhos não partirem do método do materialismo histórico e dialético “[...] que toma em consideração o desenvolvimento das forças produtivas e as relações de produção que o engendram e dele derivam".

O sociólogo Ricardo Antunes nos aponta para a atualidade da concepção marxista ao abordar a classe-que-vive-do-trabalho (ANTUNES, 2001). Hoje, essa classe inclui, na visão do estudioso, todos aqueles que vendem sua força de trabalho, envolve tanto os trabalhadores produtivos que produzem diretamente mais-valia, como os trabalhadores improdutivos que a produzem de forma indireta. ${ }^{4}$

Uma noção ampliada de classe trabalhadora inclui, então, todos aqueles e aquelas que vendem sua força de trabalho em troca de salário, incorporando, além do proletariado industrial, dos assalariados do setor de serviços, também o proletariado rural, que vende a sua força de trabalho para o capital. (ANTUNES, 2001, p.103).

A classe trabalhadora hoje exclui, para Antunes (2001), os gestores do capital e seus altos funcionários, aqueles de grande posse que vivem da especulação e dos juros, os pequenos empresários, a pequena burguesia urbana e rural proprietária.

O autor também demonstra, por meio das transformações ocorridas nas relações de trabalho do fordismo ao toyotismo, que as formas atuais de produção não são um

\footnotetext{
${ }^{4} \mathrm{O}$ trabalho produtivo é considerado como aquele que se troca diretamente por capital, ou seja, o trabalho assalariado servido a um capitalista. Já o trabalho improdutivo não é trocado por capital de forma direta, ele é executado pelos profissionais que trabalham por conta própria, mas não são grandes proprietários e não vivem de juros.
} 
novo modo de organização societária em relação ao capitalismo fordista e nem devem ser vistas como um avanço (ANTUNES, 1995).

O autor explica que antes tínhamos os modelos taylorista e fordista de produção, marcados pelo trabalho industrial, pela alta produção seriada, pelo parcelamento do trabalho e pela alta produção de excedentes (estoque). O trabalho era totalmente voltado para a produção. Porém, uma crise do capital fez emergir novas formas de produção mais rentáveis, tendo como paradigma o toyotismo (sistema capitalista de produção originado na fábrica japonesa Toyota). No lugar da produção em grande escala, o foco passou a ser a demanda do consumidor e o pequeno estoque (ANTUNES, 1995).

Essa maneira de produzir trouxe mudanças significativas na forma de se trabalhar. Se antes o trabalhador tinha horários rígidos, um trabalho muito bem definido e encontrava-se dentro de uma hierarquia clara; a nova forma de produzir trouxe a flexibilidade, a horizontalidade da produção, a terceirização da mão de obra, a necessidade de um proletário multifuncional e não mais com sua tarefa delimitada, a necessidade do trabalho em equipe e não "parcelado" como no fordismo, entre outras transformações.

A subunção do ideário do trabalhador àquele vinculado pelo capital, a sujeição do ser que trabalha ao "espírito" Toyota, à "família" Toyota, é de muito maior intensidade, é qualitativamente distinta daquela existente na era do fordismo. Esta era movida centralmente por uma lógica despótica; aquela, a do toyotismo, é mais consensual, mais envolvente, mais participativa, em verdade mais manipulatória. (ANTUNES, 1995, p. 34).

Antunes (1995) nos chama a atenção ao longo de seu texto para a precarização do novo trabalho, e seu caráter dúbio, marcado pela qualificação para alguns (avanço tecnológico) e desqualificação para outros. A alta flexibilidade do trabalho, como a contratação temporária e por meio período, apresenta-se como um problema para o trabalhador, uma vez que ele não pode mais contar com a mesma estabilidade de outrora, pois seus direitos trabalhistas são desregulamentados.

Souza (2012) também aborda as transformações ocorridas no capitalismo até o capitalismo financeiro em que vivemos hoje, no qual há a dominância do setor financeiro não só na esfera da economia, mas também “[...] sua preponderância no campo maior da luta pelo “poder” político e social”. (SOUZA, 2012, p. 40).

O autor também destaca no capitalismo financeiro o apagamento da política; o culto ao momentâneo e ao consumo imediato em obediência à velocidade do giro do 
capital; a ascensão da ideia do empreendedorismo, como se todos pudessem ser empreendedores; e a valorização dos termos da acumulação do capital, como criatividade, espontaneidade, liberdade, independência, inovação, ousadia, entre outros aspectos.

Souza (2012) expõe que a visão de mundo do novo capitalismo financeiro é assimilada por amplos setores sociais em todas as classes. É possível relacionar como parte desse movimento a perda do interesse na temática das classes sociais comentada por Murdock (2009). De acordo com ele, as pesquisas recentes ressaltam o individualismo.

É a recusa em reconhecer que a classe permanece sendo um importante princípio estrutural de cada aspecto da vida no capitalismo recente, incluindo comunicações, que bloqueia uma visão abrangente das condições contemporâneas. (MURDOCK, 2009, p. 32).

Os estudos da pesquisadora Veneza Ronsini $(2007,2012)$ também apontam para o apagamento da temática de classes sociais no discurso da mídia hegemônica e para a importância de estudar a relação de classes e a desigualdade na mídia, sobretudo na telenovela.

Em A Crença no Mérito e a Desigualdade: a recepção da telenovela no horário nobre (2012), Ronsini enfatiza a importância do estudo de Jessé Souza a respeito da naturalização das desigualdades sociais e frisa, inclusive, que o exame das telenovelas confirma a tese do sociólogo sobre as alianças simbólicas entre classe alta, classe média e popular, que excluem aquilo que o autor chama provocativamente de "ralé".

A pesquisadora traz um estudo sobre a recepção da telenovela, mais especificamente a leitura da pobreza e desigualdade por jovens da classe popular, da classe média, da classe média alta e alta. O que nos interessa em específico neste livro é a leitura que a autora realiza da representação da pobreza em algumas telenovelas da Rede Globo e a discussão levantada a respeito da representação da pobreza na mídia, e nas telenovelas, de um modo mais geral.

Ronsini (2012) utiliza a teoria das mediações do teórico Jesús Martín-Barbero (2009) para compreender a relação da comunicação com a cultura e aborda as mediações da socialidade, da ritualidade e da tecnicidade. Aproveitaremos neste trabalho apenas as colocações sobre a mediação da tecnicidade, pois é neste item que se encontra a representação da pobreza na mídia. 
A autora explica que na TV aberta, a imagem de um Brasil moderno e urbano na telenovela das oito apresenta uma sociedade de classes distintas, mas harmônicas. Segundo sua análise, a mídia promove a conformação de subjetividades aptas ao governo de si, mas inaptas à percepção dos constrangimentos sociais; o indivíduo é estimulado a acreditar que a cidadania é uma questão individual (RONSINI, 2012).

Um breve levantamento realizado pela autora, sobre estudos que procuram entender a representação dos pobres na mídia, constatou apenas dois trabalhos que tratam da pobreza na telenovela - a tese de doutorado de Maria Carmem J. de Souza, Representação do popular e campo da telenovela: um close em Benedito Ruy Barbosa (1999) e a pesquisa de Maria Lília Junqueira, Desigualdades sociais e telenovelas: Relações ocultas entre ficção e reconhecimento (2009).

De acordo com Ronsini (2012) o trabalho de Maria Carmem J. de Souza aborda a construção do popular em 25 telenovelas do horário nobre da Rede Globo, exibidas nas década de 1980 e 1990, e conclui que a telenovela tende a enfatizar a ascensão social pelo trabalho ou pelo casamento, mas que ao mesmo tempo há profissionais consagrados que trazem a denúncia da reprodução social, como o autor Benedito Ruy Barbosa e o diretor Fernando Carvalho em Renascer (1993), telenovela que não trouxe a ascensão social como solução para as situações de pobreza. Além disso, Souza (apud RONSINI, 2012) demonstra que o lugar predominante do popular nas produções analisadas é nas tramas paralelas. ${ }^{5}$

Na visão de Ronsini (2012), a telenovela atualiza comportamentos e valores, debate preconceitos, mas raramente faz crítica baseada na desigualdade de classes. A autora expõe que é muito raro que os autores abordem a divisão de classes sociais como ocorreu em Renascer, pois a desigualdade é humanizada nas narrativas pelas relações sociais entre ricos, remediados e pobres. "O tom político de uma novela prima, quase sempre, pelo comedimento, mesmo para autores que se consagraram como "críticos" como Benedito Ruy Barbosa [...]" (RONSINI, 2012, p. 99).

Esses levantamentos levam a autora a formular a hipótese de que a telenovela contribui para que os jovens acreditem na superação dos problemas sociais, repetindo as soluções apresentadas pelo melodrama que exaltam qualidades individuais, o que está

\footnotetext{
${ }^{5}$ Porém, após o período estudado pela autora, a partir de 2002 com o aumento da renda de uma parte da população, já comentado aqui, algumas produções culturais passam a destacar as classes populares, como o que ocorreu com as telenovelas Senhora do Destino (2004, 2005) e Duas Caras (2007, 2008), ambas de Aguinaldo Silva. (JUNQUEIRA, 2009).
} 
vinculado às aspirações correspondentes às lógicas individualizadas do sistema neoliberal.

Outro trabalho que trata do tema abordado por Ronsini (2012) é o de Maria Lília Junqueira (2009), que faz um estudo de recepção que analisa o discurso de telespectadores de diferentes classes sobre as desigualdades sociais presentes em algumas telenovelas.

Junqueira (2009), ao argumentar como as desigualdades são tratadas na telenovela, faz um levantamento sobre as matrizes perceptivas, afetivas e morais na criação das telenovelas. A autora argumenta que nos anos 1960 e 1970 surgem duas matrizes: o romantismo oitocentista e o modernismo-personalista. A primeira é baseada na literatura romântica e a segunda baseia-se no movimento literário modernista, caracterizado pela busca da identidade nacional e a revelação das desigualdades no país.

"O modernismo-personalista pode ser identificado facilmente a partir dos modelos ideais desenvolvidos por Roberto Damatta e se ajustam perfeitamente aos estereótipos de personagens e relações construídos nas telenovelas" (JUNQUEIRA, 2009, p. 23).

Até 1980, a autora explica que as telenovelas produziam uma única estrutura de percepção e sentimento das desigualdades, o patriarcalismo, a predominância da dominação do homem branco sobre mulheres, jovens, negros e crianças, que se dividia em duas matrizes principais: as adaptações do Romantismo do século XVIII e as obras modernistas como as de Jorge Amado (JUNQUEIRA, 2009).

A partir de então, essas matrizes vão se desdobrando em novas formas, afirmativas ou inversas, mas que mantêm as bases das duas primeiras. Da vertente do romantismo vieram o romantismo do cotidiano, o romantismo futurista, o romantismo de experiências e o romantismo humorístico; da vertente do modernismo-personalista originaram-se o modernismo personalista globalizado, o modernismo personalista afirmativo, o modernismo personalista inverso rural e o modernismo personalista inverso realista mágico (JUNQUEIRA, 2009).

A autora esclarece que chama de personalismo uma interpretação moral do Brasil que busca uma definição do país, de acordo com suas características híbridas e da dificuldade de situá-lo na história das nações; trata-se de uma visão construída sobre a teoria do patrimonialismo, internalizada pelo senso comum e pela mídia, que explica a cultura brasileira por meio da lógica dos sentimentos e das relações sociais (JUNQUEIRA, 2009). Esse paradigma, como já demonstramos, é criticado por Souza (2006). 
De acordo com avaliação de Ronsini (2012), a ideologia do personalismo permanece presente nas relações pessoais e sociais da telenovela. Para a autora, a telenovela continua cultivando o personalismo, pois os conflitos de classe são resolvidos por via moral, “[...] as hierarquias são equilibradas pela conquista individual baseada nas relações pessoais.” (RONSINI, 2012, p. 121).

No que diz respeito ao Romantismo, a autora afirma que a solução encontrada para o conflito de classe trazido pela relação entre personagens do núcleo pobre e rico está inspirada no romantismo do século XIX ou no romantismo renovado, que seria o casamento entre pessoas de classes sociais diferentes, a ascensão profissional e o esforço individual (RONSINI, 2012).

Assim, demonstra que a narrativa da telenovela funciona baseada na ideologia meritocrática e do desempenho, pois explica a mobilidade social ascendente como consequência do trabalho, da competência, do esforço individual, além de trazer a ideologia do personalismo, na qual as relações pessoais definem carreiras e chances individuais de ascensão social.

Se a denúncia de preconceitos baseados em distinções de classe pode ser vista como uma posição negociada do gênero melodramático, ela não serve para questionar as assimetrias, mas para afirmá-las em um tom humanizado. No final, compactua-se com a injustiça social, reproduz-se que ser pobre é bom, que o "povo" é mais feliz que a "elite" e que ascender socialmente depende do esforço individual. (RONSINI, 2012, p 183).

É pertinente destacar que, além da importante obra de Ronsini (2012) e do levantamento realizado pela própria autora sobre trabalhos que tratam da pobreza na telenovela - que destacou os estudos de Maria Carmen J. de Souza e Maria Lilia Junqueira (2009), já comentados aqui - consideramos também a seleção feita por Figaro e Grohmann (2013) de obras, apenas livros, que abordam a temática classe social em estudos de recepção; dentre elas estão algumas obras que tratam do tema na telenovela.

Além de Junqueira (2009) e Ronsini (2012), temos: A Leitura Social da Novela das Oito, de Ondina Fachel Leal $(1983)^{6}$, Vivendo com a Telenovela de Lopes, Borelli e Resende (2002) e O Fascínio de Sherazade de Roberta Manuela de Andrade (2003).

Leal (1983) faz um estudo de recepção da trama Sol de Verão, escrita por Manoel Carlos e exibida de outubro de 1982 a março de 1983 na Rede Globo, às 20 horas na

\footnotetext{
${ }^{6}$ Figaro e Grohmann (2013) se referem à obra editada em 1985, neste trabalho utilizamos a dissertação de mestrado, que deu origem à obra, de 1983.
} 
época. A pesquisa levou em consideração a recepção em dois grupos diferentes, um de classe alta, denominada pela autora como classe dominante, e outro de classes populares. Seu trabalho revela as diferentes leituras da telenovela feitas por esses dois grupos.

Embora o trabalho de Leal (1983) não aborde a desigualdade e as classes sociais no discurso da telenovela, que é o interesse desta dissertação, a autora traz conclusões importantes de serem consideradas aqui.

Uma das conclusões da autora é que no grupo de classes populares a novela e a televisão são vistas como uma fala moderna, culta e dominante e como uma instância de participação neste domínio, enquanto no grupo de classe dominante, a telenovela é considerada popular, não pertencente ao universo erudito, além de ser criticada como não realista (LEAL, 1983).

A autora ressalta que o argumento da trama Sol de Verão se dá no aqui e agora, se atualiza no vestir e no falar de seus personagens e nos comentários que são notícias diárias no Brasil no momento em que se desenrola a trama, como a ida do Brasil ao FMI e a homenagem a Elis Regina no aniversário de sua morte, bem como as datas festivas como o Natal e o Carnaval, "[...] fazendo com que as datas e eventos reais e fíctícios coincidam”. (LEAL, 1983, p. 141). Além disso, a trama trata de histórias de famílias e afetos que também estão presentes nas famílias e nos cotidianos. Essas características garantem a eficácia da mensagem da telenovela na visão de Ondina Leal.

A estudiosa também destaca que a telenovela concilia o elemento de reprodução social e outro de transformação em seu texto.

A novela é, pois, instância legitimadora e legitimada que na sua natureza de bem simbólico da indústria cultural, que é consumido por sujeitos socialmente diferenciados, busca conciliar o velho e o novo. As normas de conformidade com a ordem social e as subversões desta ordem começam a ser recompensadas no próprio texto. (LEAL, 1983, p. 141).

A obra Vivendo com a Telenovela (LOPES; BORELLI; RESENDE, 2002) também não trata do modo como a telenovela representa as classes sociais ou a desigualdade e sim é um estudo de recepção que vale a pena ser abordado devido à sua importância para a área. A pesquisa versa sobre a recepção da telenovela $A$ Indomada (1997), exibida pela Rede Globo e escrita por Aguinaldo Silva e Ricardo Linhares, por quatro famílias de classes sociais diferentes, a partir de quatro mediações: o cotidiano familiar, subjetividade, gênero familiar e videotécnica. 
As autoras argumentam que o conceito de classe social aparece na pesquisa como diferença que se expressa em habitus, “[...] que é produto de condicionamentos sociais associados à posição correspondente" (LOPES; BORELLI; RESENDE, 2002, p. 45). Também explicam que tentaram trabalhar a posição social etnograficamente no cotidiano familiar, "[...] mostrando que apesar de as lógicas das diferenças não se esgotarem na diferença social da classes, essa diferença articula as outras” (LOPES; BORELLI; RESENDE, 2002, p. 45-46).

Já a obra O Fascínio de Sherazade de Roberta Manuela Barros de Andrade (2003) traz um estudo de recepção com telespectadores de classes médias e populares da telenovela Suave Veneno (1999), exibida na Rede Globo. A autora revela as diversas leituras da telenovela possibilitadas por essas duas diferentes posições sociais, e também as similaridades entre elas.

Ademais, pesquisamos dissertações de mestrado e teses de doutorado a partir do ano 2000 até o momento presente, bem como artigos publicados, no mesmo período, em anais do Congresso Nacional da Compós (Associação Nacional dos Programas de PósGraduação em Comunicação) e do Congresso Nacional da Intercom (Sociedade Brasileira de Estudos Interdisciplinares da Comunicação) e também na Revista Intercom que abordassem a mesma temática desta dissertação. Além de trabalhos dos autores já citados, encontramos a dissertação de mestrado de Renata Guedes Mourão Macedo (2013) Espelho mágico: empregadas domésticas, consumo e mídia, defendida na USP, no departamento de Antropologia.

Mourão Macedo (2013) traz um estudo etnográfico sobre o consumo midiático de empregadas domésticas e, para isso, aborda as transformações na profissão e a ascensão de uma "nova classe C" que trouxeram mais visibilidade a elas nas produções ficcionais. A autora dedica um capítulo de sua dissertação à telenovela Cheias de Charme, discutindo a representação doméstica na trama e como as empregadas entrevistadas a receberam. "Além das questões trabalhistas, a telenovela também tematizou de maneira lúdica e esquemática a desigualdade social e a dificuldade de acesso a serviços públicos de qualidade, como hospitais e escola" (MOURÃO MACEDO, 2013, p. 112).

Apesar disso, a autora chama a atenção para o fato de Cheias de Charme reproduzir estereótipos relacionados ao emprego doméstico, presentes em ficções anteriores, como o erotismo e a sensualidade. Frisa ainda o fato de Cheias de Charme 
promover as empregadas domésticas a consumidoras, devido ao interesse do mercado, e mostrar que a ascensão social é possível.

Talvez seja essa a chave para compreendermos a principal ideologia de Cheias de Charme: ao representar empregadas domésticas bonitas, bem vestidas, otimistas, possuindo itens de consumo de última geração e tendo uma casa arrumada, ainda que na favela, tais características revelaram-se indicativas de que a diferença entre a 'empreguete' e a 'madame' é pequena e, a qualquer momento, poderá ser superada. Assim, ao invés de uma desigualdade social naturalizada e intransponível, encena-se uma desigualdade social conjuntural e passageira. (MOURÃO MACEDO, 2013, p. 121-122).

Podemos relacionar os dados levantados por Mourão Macedo (2013) com o estudo de Ronsini (2012) sobre a ideologia meritocrática e o individualismo presente na representação das desigualdades sociais nas telenovelas, pois Macedo demonstra que a trama oferece a possibilidade de ascensão como parte de um esforço individual.

No que diz respeito aos artigos pesquisados, temos o trabalho Representações ficcionais à mesa: espaços e estilos de alimentação como diferenciação social (2012) da pesquisadora Márcia Tondato. A autora traz um importante estudo sobre a representação da alimentação e dos espaços de refeição na trama Fina Estampa (2011/2012) em um contexto de mobilidade material. Destaca em sua análise os contrastes sociais nos momentos ficcionais de refeições, mediante personagens de diferentes estratos sociais, além dos aspectos culturais e tradicionais evocados pelas cenas.

Além do trabalho citado acima, percebemos que dos artigos que mais se aproximaram do nosso tema, a maioria é de autores já mencionados aqui, enquanto os mais recentes, que abordaram a representação da "nova Classe C" em tramas como Cheias de Charme e Avenida Brasil, fazem parte de pesquisas ainda muito iniciais e, assim, não foi possível trazer suas contribuições para esta pesquisa.

Desse modo, das pesquisas citadas a respeito do tema podemos considerar que a de Ronsini (2012) é a que traz mais contribuições no que tange a representação de classe social e desigualdade na telenovela. Ao relacionar o discurso da telenovela com a economia neoliberal, a ideologia do desempenho e meritocrática, o trabalho da autora nos fornece importante referencial teórico para um estudo da midiatização do consumo e do sentido de classe social na telenovela. 


\subsection{ASPECTOS PRELIMINARES DA MIDIATIZAÇÃO DO CONSUMO E DO SENTIDO DE CLASSE EM AVENIDA BRASIL E CHEIAS DE CHARME}

Embora Ronsini (2012) aborde um momento que precede o que vem sendo chamada a representação de uma "nova classe C", podemos estender, de forma preliminar, suas críticas às produções Avenida Brasil (2012) e Cheias de Charme (2012), uma vez que os próprios termos "nova classe C" ou "nova classe média" fazem parte de uma visão economicista e neoliberal que corrobora com a ideologia do desempenho e meritocrática (RONSINI, 2012; SOUZA, 2012).

Em Avenida Brasil, o personagem Tufão torna-se rico como jogador de futebol, enquanto as empregadas de Cheias de Charme ganham dinheiro e fama com um trio musical. Ambas as situações representam a ascensão econômica por um esforço individual, desvinculada da vivência de classe social, o que corrobora, em um primeiro olhar, com a ideologia meritocrática exposta por Ronsini (2012).

Em Cheias de Charme, trama que mostra a oposição entre patroas e empregadas, as relações pessoais como definidoras de carreiras e chances de ascensão abordadas por Ronsini (2012) são mais evidentes. Maria da Penha, a mais pobre das três empregadas, torna-se amiga de sua ex-patroa e do advogado rico Dr. Otto. Graças a esse último passa a frequentar eventos culturais considerados da cultura legítima, como óperas. Enquanto seu irmão, Elano - o único branco da família e que não herdou os costumes populares dos outros parentes -, formado em Direito graças ao esforço da irmã e seu esforço próprio, consegue boas chances em sua carreira devido ao reconhecimento do seu bom caráter por Dr. Otto.

De acordo com essas breves características levantadas, podemos argumentar que, como expõe Ronsini (2012), não é proposta da telenovela, de maneira geral, fazer críticas sociais de forma profunda. Ela prioriza a harmonia nas representações de classe, como ocorria com o folhetim na dinâmica provocação e pacificação (MARTíNBARBERO, 2009). Porém, há peculiaridades na midiatização do sentido de classes em Avenida Brasil e Cheias de Charme. Não podemos ignorar que ambas as produções foram inovadoras ao retratar o popular, principalmente Avenida Brasil que foi considerada um fenômeno midiático e tinha a maioria de seus personagens como representantes do subúrbio. 
Existem aspectos retratados que dialogam com atributos considerados pelos sociólogos como pertencentes à nova classe trabalhadora, como o convívio com a comunidade e o fato dela não querer deixar o seu local de origem, como ocorreu com o personagem Tufão, que após enriquecer constrói mansão no mesmo bairro suburbano onde morava, e Maria da Penha que não aceita mudar-se da comunidade Borralho após seu sucesso.

\begin{abstract}
A nova classe trabalhadora não participa desse jogo da distinção que caracteriza as classes alta e média. Como na reportagem de um número recente da revista Negócios e Finanças, que foi pensada como um "elogio" a essa classe, mas que estranha que a classe $C$ não se mude de bairro quando ascende economicamente, ela tem opções e gostos muito diferentes. Ela é "comunitária" e não "individualista", por exemplo, nas suas escolhas. Ficar no mesmo bairro onde se tem amigos e parentes é mais importante que se mudar para um bairro melhor (SOUZA, 2012, p. 49-50).
\end{abstract}

Além disso, o autor expõe que a nova classe trabalhadora, em sua formação, não teve o mesmo acesso privilegiado ao capital cultural das classes médias e nem ao capital econômico das classes altas. Do mesmo modo, Avenida Brasil e Cheias de Charme retratam os personagens que ascenderam financeiramente, mas continuam com o mesmo hábito cultural. Sobretudo, em Avenida Brasil, podemos identificar diversas cenas reveladoras de tal aspecto, como o gosto por filmes de ação e a não compreensão de filmes considerados intelectuais pela personagem Muricy, mãe de Tufão, por exemplo. Trata-se de uma estratificação de distinção de gostos.

Em Maria da Penha é evidente o fato dela não ter herdado o acesso a capital econômico, pois mesmo depois de enriquecer ela se demonstra resistente a determinados gastos, ela se recusa, por exemplo, a pagar um valor muito alto em roupas de grife. O seu poder econômico de consumo aumenta, mas sua lógica de pensar é o de sua classe social de origem.

Desse modo, acredita-se que, em um primeiro momento, a construção midiática do consumo e do sentido de classe social nas duas telenovelas traz tanto elementos que podem ser considerados puramente midiáticos - no que se refere ao modo peculiar da ficção folhetinesca tratar assuntos sociais -, como apresenta indícios de diálogo com a realidade social da nova classe trabalhadora e carrega propriedades que afirmam a hegemonia do discurso neoliberal e meritocrático.

Vale ressaltar que os aspectos representacionais que corroboram com a visão de uma "nova classe média" de base economicista (SOUZA, 2012) não poderiam ser 
considerados exclusivos da telenovela e puramente midiáticos uma vez que, como pontua o próprio teórico Jessé Souza, esse discurso faz parte da simbologia de um senso comum que legitima as diferenças sociais e está na mídia e na sociedade como um todo. Caberia uma análise sobre o que existe de midiático no discurso neoliberal vigente para aprofundar o assunto.

Discutir a midiatização do consumo e do sentido de classe social nesse contexto nos exige, então, considerar a mídia dentro do processo histórico-social da qual faz parte para entendermos o seu papel na sociedade neoliberal hoje. Como argumenta o teórico Raymond Williams (2011), os meios de comunicação são meios de produção porque a comunicação e seus meios materiais são intrínsecos às formas humanas de trabalho e de organização social.

Por esse ponto de vista, este estudo requer um retorno ao materialismo histórico e à dialética marxista para situarmos socialmente o homem, sua produção e linguagem a fim de e partirmos, assim, para a análise discursiva.

Acredita-se que um estudo que privilegie a análise do discurso em Avenida Brasil e Cheias de Charme pode nos trazer possíveis respostas quanto às nuanças da construção midiática do consumo e do sentido de classe social nessas tramas - o que seria puramente midiático? Quais aspectos dialogam com a realidade social discutida pelos sociólogos e com a visão econômica hegemônica? E quais aspectos discursivos apontariam para mudanças? 


\section{ANÁlise DiSCURSiVA PARA O ESTUdo DA MIDIATIZAÇÃo DO CONSUMO E DO SENTIDO DE CLASSE SOCIAL}

Este capítulo pretende tratar, sucintamente, do materialismo histórico e da dialética marxista para fundamentar uma concepção social e histórica do homem e sua linguagem. Objetiva-se, assim, demonstrar o caráter dialético da linguagem, enquanto produto e produtora social.

De acordo com esse enfoque, abordaremos aspectos das teorias do discurso, com o aporte do teórico Mikhail Bakhtin e uma mescla da Análise do Discurso Francesa e a Análise do Discurso Crítica (ADC), de vertente inglesa.

Com base nesta abordagem, delinearemos um protocolo metodológico para analisar a midiatização do consumo e do sentido de classe social em Avenida Brasil e Cheias de Charme, mediante a seleção de determinadas cenas.

\subsection{LINGUAGEM E DISCURSO, CARÁTER SÓCIO-HISTÓRICO E DIALÉTICO}

Na apresentação da edição de 2007 da obra A Ideologia Alemã de Karl Marx e Friedrich Engels, originalmente escrita entre 1845 e 1846, o sociólogo Emir Sader traz considerações esclarecedoras capazes de guiar o leitor à linha de pensamento que os pensadores desenvolveram ao longo da obra, na qual - nas palavras de Sader - o materialismo histórico de Marx ganha formato.

De acordo com Sader (MARX; ENGELS, 1845-1846, 2007, apresentação), para a busca da verdade na filosofia, de um modo geral, sempre houve interesse por parte dos pensadores pela dicotomia entre sujeito e objeto. A verdade como ausência de contradição entre esses dois elementos faz parte do pensamento aristotélico que perdurou por muito tempo na humanidade e teve continuidade com grandes pensadores como René Descartes e Immanuel Kant. O filósofo Georg Wilhelm Friedrich Hegel foi quem mudou essa forma de pensamento, trazendo uma compreensão subjetiva a essa dicotomia, questionando a concepção da objetividade.

Sader explica (MARX; ENGELS, 1845-1846, 2007, apresentação) que para Hegel, a primeira e maior das questões para o conhecimento do mundo e do estar do 
homem nele é a busca das razões pelas quais sujeito e objeto aparecem diferenciados e contrapostos. A apreensão da verdade do real para Hegel consiste na explicação de como o real se dividiu entre sujeito e objeto. O filósofo aponta para dois movimentos, o primeiro diz respeito à perda da unidade entre mundo e consciência, há estranhamento e alienação; o segundo movimento trata da retomada da unidade perdida, passagem da consciência em si à consciência para si.

Segundo Sader, com Hegel, afirma-se, pela primeira vez na história da filosofia, que o mundo é produto do trabalho humano, como realidade histórica construída coletivamente pelos homens (MARX; ENGELS, 1845-1846, 2007, apresentação).

A Ideologia Alemã (MARX; ENGELS, 1845-1846, 2007) retoma a trajetória hegeliana, mas ao mesmo se contrapõe a ela, pois Hegel parte da crítica das ilusões do conhecimento (ideologia para Marx) e Marx e Engels partem do social, do material, da realidade concreta e não da ideologia pura. A alienação entre sujeito e objeto para Marx se dá no trabalho, pois nele os homens não têm consciência de sua participação na criação no mundo e se sentem um objeto no sistema de produção.

Conforme expõe Sader:

A capacidade de trabalho faz com que o homem seja um ser histórico; isto porque cada geração recebe condições de vida e as transmite a gerações futuras, sempre modificadas - para pior ou para melhor. Embora tenha o potencial transformador da realidade, o que o homem mais recusa é trabalhar. Foge do que o tornaria humano porque não se reconhece no que faz, no que produz, no mundo que transforma. Porque trata-se de trabalho alienado. (MARX; ENGELS, 1845-1846, 2007, p. 12).

O ponto de vista da filosofia pura, que não prioriza o homem real na sociedade, é o que faz Marx criticar outros autores alemães de base hegeliana ao longo de $A$ Ideologia Alemã (2007). De acordo com Marx, a visão desses pensadores alemães concebe a história apenas pela ótica oficial, aquela contatada pelos críticos e pensadores, e não a história material real dos homens.

Neste ponto está implicada a concepção de indivíduo de Marx abordada por Adam Schaff em O Marxismo e o Indivíduo (1967). Schaff explica que a questão central para Marx, e para o socialismo, é o indivíduo concreto, vivo e real. O homem biológico também é considerado, mas junto do social. Ao mesmo tempo em que fisiologicamente o ser humano tem potencialidades inatas para se desenvolver, a sua consciência se dá na base material, conectada aos modos de produção e à fase histórica na qual nasce. $\mathrm{O}$ 
homem, do ponto de vista marxista, é um produto da sociedade e também o seu criador, em uma relação dialética.

O homem, além de um produto da evolução biológica das espécies, é um produto histórico, um produto de certa forma mutável nas diversas etapas da evolução da sociedade, conforme pertença a uma ou outra das classes e camadas de uma mesma sociedade. (SCHAFF, 1967, p. $65)$.

Schaff (1967) resume três concepções de indivíduo em Marx. São elas: o indivíduo como parte da natureza, o indivíduo como parte da sociedade e o indivíduo como fruto da autocriação. Nesta última concepção está o argumento de que o homem se autocria por meio do trabalho, ou seja, o ser humano é o construtor de sua história.

Em A Ideologia Alemã, Marx e Engels (1845-1846, 2007) explicam que a história da humanidade está conectada com a história da indústria e das trocas. Existe, para os pensadores, uma conexão materialista entre os homens, que dependem da necessidade e dos modos de produção, que são tão antigos quanto o próprio homem.

Marx e Engels (1845-1846, 2007) expõem que a consciência do homem não é pura e está relacionada à matéria, assim como a linguagem. Ambas nascem da prática, da necessidade de intercâmbio com outros homens. Desse modo,os pensadores demonstram que as formas de produção de cada época histórica influenciam o seu modo dominante de pensamento. "As ideias de classe dominante são, em cada época, as ideias dominantes, isto é, a classe que é a força material dominante da sociedade é, ao mesmo tempo, sua força espiritual dominante." (MARX; ENGELS, 1845-1846, 2007, p. 47). ${ }^{7}$

É pertinente recorrer aos estudos dos autores marxistas Alexis Leontiev (2004), Lev SemenovichVigotski (2005) e Adam Schaff (1974) que demonstram a importância da interação social e da atividade humana na formação da linguagem, da consciência e do pensamento no homem.

De acordo com o pesquisador Alexis Leontiev na obra $O$ desenvolvimento do psiquismo (2004), a hominização de nossos antepassados se deve ao aparecimento do trabalho. Ele elucida que o cérebro da espécie humana se desenvolve ao longo dos tempos, de gerações, por meio das transformações sociais, das atividades desenvolvidas pelo homem e da formação da consciência.

O autor destaca que o trabalho só poderia se desenvolver entre animais que vivessem em grupo e apresentassem formas desenvolvidas de vida em comum e

\footnotetext{
${ }^{7}$ Classe dominante para Marx e Engels é aquela que tem à sua disposição os meios de produção material.
} 
também entre seres com formas desenvolvidas de reflexo psíquico da realidade. $\mathrm{Ou}$ seja, há um componente inato dos homens e um componente social, um influenciando o outro.

Leontiev (2004) aclara que a consciência só pode existir nas condições de existência da linguagem, que aparece ao mesmo tempo que ela no processo de trabalho. "O nascimento da linguagem só pode ser compreendido em relação com a necessidade, nascida do trabalho, que os homens sentem de dizer alguma coisa" (LEONTIEV, 2004, p. 92). O estudioso afirma que a produção da linguagem, da consciência e do pensamento está misturada na origem à atividade produtiva e à comunicação material dos homens.

O pensador Vigotski (2005), por sua vez, enfatiza a relação entre pensamento e linguagem. No que tange aos estudos das espécies, o autor expõe a existência de uma fase pré-linguística no desenvolvimento do pensamento e uma fase pré-intelectual no desenvolvimento da fala.

No estudo da evolução de um ser, o autor também demonstra que pensamento e fala estão separados até determinado momento da vida infantil em que ambos se encontram e dão início a uma nova forma de comportamento, pois por um longo tempo, a palavra é para a criança uma propriedade - do objeto, mais que um símbolo dele. (VIGOTSKI, 2005).

O desenvolvimento do pensamento é determinado pela linguagem, pelos instrumentos linguísticos do pensamento e pela experiência sociocultural da criança. Do mesma maneira, o pensamento verbal na espécie humana foi se desenvolvendo ao longo dos anos, por meio da interação com os outros e de acordo com o momento histórico da humanidade.

O pensamento verbal não é uma forma de comportamento natural e inata, mas é determinado por um processo histórico-cultural e tem propriedades e leis específicas que não podem ser encontradas nas formas naturais de pensamento e fala. Uma vez admitido o caráter histórico do pensamento verbal, devemos considerá-lo sujeito a todas as premissas do materialismo histórico, que são válidas para qualquer fenômeno histórico da sociedade humana. (VIGOTSKI, 2005, p. 63).

De modo similar, Adam Schaff (1974) argumenta que a linguagem tem papel ativo no conhecimento humano, no pensamento e na cultura. Para o autor, as línguas são os suportes do pensamento conceitual, elas constituem o fundamento social do pensamento individual e transmitem aos indivíduos a experiência e o saber das gerações 
passadas e também se apropriam dos novos resultados do pensamento individual para transmiti-los às gerações futuras. O homem recebe da sociedade a unidade linguagempensamento; trata-se do ponto de partida e fundamento de todo pensamento individual, que ao mesmo tempo é criativo e inovador por meio da linguagem.

$\mathrm{O}$ autor pontua que a linguagem influencia o nosso modo de perceber a realidade, é reflexo específico da realidade e criadora da nossa imagem do mundo. Além disso, é influenciada pelo mundo objetivo e também pelo subjetivo, ou seja, pelo modo que determinado povo percebe o mundo.

Schaff (1974) ilustra esses atributos da linguagem com o exemplo dos esquimós que enxergam e nomeiam diversos tipos de neve, diferente do montanhês polaco que enxerga apenas algumas e do citadino que vê uma única. Ou seja, o mundo prático, no caso o frio e a sobrevivência na neve, influencia o modo de cada povo enxergar a realidade e se articular com ele.

O estudioso também aclara que a sociedade transmite por gerações preconceitos e estereótipos através da linguagem.

[...] a sociedade transmite ao indivíduo - com a linguagem e graças à linguagem - certos estereótipos de comportamento, que agem sobre a consciência (como sobretudo o que está ligado à linguagem) com tanto mais força quanto são, tendo em atenção o seu carácter ordinário e sugestivo, mais difíceis de decifrar e, portanto, aceites na maior parte dos casos como coisas "naturais" (SCHAFF, 1974, p. 265-266).

Temos, então, a relevância da prática e da atividade humana na formação da linguagem, bem como a importância da bagagem histórico-social e cultural. Nesse sentido, é imprescindível abordar o trabalho realizado pelo filósofo da linguagem Mikhail Bakhtin e seu círculo de estudo, que partem de uma concepção histórica, social e cultural da linguagem. Os estudos de Bakhtin, que viveu do fim do século XIX até meados do século XX, anteciparam muitas das ideias desenvolvidas posteriormente nas teorias das análises discursivas.

A pesquisadora das obras bakhtinianas Beth Brait (2012) sustenta que, apesar das teorias do filósofo não exporem categorias que sejam facilmente aplicáveis, o conjunto das obras do Círculo de Bakhtin (constituído por Bakhtin, Volochinov, Medvedev e outros) motivou o nascimento de uma análise/teoria dialógica do discurso.

Brait conta que o autor exibe, ao longo de seus trabalhos, a concepção de metalinguística, que supõe um estudo que ultrapassa os limites da Linguística, sem excluí-la. A visão de Bakhtin leva em conta os aspectos discursivos que apontam para 
contextos mais amplos (extralinguísticos), mas ao mesmo tempo considera que o trabalho metodológico analítico e interpretativo com textos/discursos herda da Linguística a possibilidade de estudar campos semânticos, por exemplo, analisar organizações sintáticas (BRAIT, 2012).

Por conseguinte, a abordagem do discurso se dá a partir de um ponto de vista interno e externo. Ambos se complementam, e não podem ser considerados isoladamente. "Excluir um dos polos é destruir o ponto de vista dialógico proposto e explicitado pela teoria e pela análise e dado como constitutivo da linguagem." (BRAIT, 2012, p. 13).

É importante salientar que a mobilização do pensamento de Bakhtin presente em seus textos é fazer da análise um processo de diálogo entre sujeitos. Assim, as principais características da teoria/análise dialógica do discurso enfatizadas por Brait (2012) são: alteridade constitutiva (que influenciou diversos autores do discurso e da linguística a formularem outros conceitos); o dialogismo como constitutivo de qualquer discurso e a dimensão especial da interação.

Dentro dessa perspectiva, a autora destaca a obra Marxismo e filosofia da linguagem (2002) como uma espécie de "terceira margem dos estudos da linguagem", pois traz a possibilidade de estudá-la por meio da historicidade, dos sujeitos e do social, possibilitando observá-la em uma combinação entre seu aspecto sistemático e criativo (BRAIT, 2012).

Nessa obra, Bakhtin (VOLOCHINOV, 2002) traz importantes argumentos sobre o caráter ideológico da linguagem, possibilitado pela existência dela enquanto signo social. Este último é um fenômeno do mundo exterior e não de um mundo individualizado, resulta de um consenso entre indivíduos socialmente organizados em um processo de interação, por isso o ideológico tem o seu lugar no material social sígnico. "O domínio do ideológico coincide com o domínio dos signos: são mutuamente correspondentes. Ali onde o signo se encontra, encontra-se também o ideológico." (BAKHTIN/VOLOCHINOV, 2002, p. 32).

Para o pensador russo, é justamente o caráter semiótico das ideologias que as colocam sob a mesma definição geral. Ao contrário do que pensa o idealismo e o psicologismo, Bakhtin acredita que a compreensão só pode manifestar-se por um material semiótico, a própria consciência se afirma como realidade por meio dos signos.

Assim como alegam os outros autores marxistas citados anteriormente, Bakhtin frisa que a consciência não pode derivar diretamente da natureza e a ideologia não pode 
derivar da consciência, pois esta última adquire forma e existência nos signos criados por um grupo organizado no processo das relações sociais. (BAKHTIN/ VOLOCHINOV, 2002).

Nessas circunstâncias, as formas de comunicação verbal são determinadas pelas relações de produção e pela estrutura sociopolítica de cada época e grupo social. E o processo hierárquico assume um papel importante na interação verbal, acaba por refletir a luta de classes. (BAKHTIN/VOLOCHINOV, 2002).

Apesar dos signos ideológicos serem compartilhados por pessoas de diferentes classes sociais, eles apresentam índices de valor contraditórios, que expressam a luta entre elas. Ademais, a classe dominante abafa esse conflito ao conferir ao signo ideológico um caráter intangível, acima das diferenças sociais. (BAKHTIN/ VOLOCHINOV, 2002)

Ainda assim, o signo é suscetível a mudanças e a palavra, segundo Bakhtin/Volochinov (2002), é o indicador mais sensível das transformações sociais, pois está presente em todas as relações sociais. Ela é o meio no qual são produzidas mudanças que ainda não engendraram uma forma ideológica acabada. Ela registra as formas transitórias e efêmeras das mudanças sociais.

O autor afirma (2002) que a palavra é o fenômeno ideológico por excelência, o modo mais puro sensível de relação social e material privilegiado da comunicação na vida cotidiana. Para Bakhtin, a palavra também é um signo neutro, na medida em pode preencher qualquer função ideológica, como estética, científica, moral e religiosa. Além disso, o filósofo expõe que a palavra também é utilizável como signo interior, pois não necessariamente se expressa externamente.

Todas as propriedades da palavra que acabamos de examinar - sua pureza semiótica, sua neutralidade ideológica, sua implicação na comunicação ordinária, sua possibilidade de interiorização, e finalmente, sua presença obrigatória, como fenômeno acompanhante em todo ato consciente - todas essas propriedades fazem dela o objeto fundamental do estudo das ideologias. (BAKHTIN/ VOLOCHINOV 2002, p.38).

Essa palavra capaz de registrar as mudanças efêmeras está, segundo Bakhtin, na ideologia do cotidiano. O teórico faz uma separação entre dois tipos de ideologia, a ideologia do cotidiano e os sistemas ideológicos constituídos. A primeira diz respeito à palavra interior e exterior desordenada que ainda não se fixou em um sistema, que acompanha todos os nossos atos, gestos e estados de consciência. Já os sistemas 
ideológicos são constituídos, por exemplo, da moral social, da ciência, da arte e da religião, e conservam um elo orgânico com a ideologia do cotidiano, como faz uma obra literária.

Em cada época de sua existência histórica, a obra é levada a estabelecer contatos estreitos com a ideologia cambiante do cotidiano, a impregnar-se dela, a alimentar-se da seiva nova secretada. É apenas na medida em que a obra é capaz de estabelecer um tal vínculo orgânico e ininterrupto com a ideologia do cotidiano de uma determinada época, que ela é capaz de viver nesta época (é claro, nos limites de um grupo social determinado). Rompido esse vínculo, ela cessa de existir, pois deixa de ser apreendida como ideologicamente significante. (BAKHTIN/VOLOCHINOV, 2002. p. 119)

Desse modo, o autor delineia a natureza social e dialógica de toda enunciação, que é determinada pelo exterior e não interior, pois não é a atividade mental que organiza a expressão e sim o contrário, como já foi demonstrado. "A situação social mais imediata e o meio social mais amplo determinam completamente e, por assim dizer, a partir do seu próprio interior, a estrutura da enunciação" (BAKHTIN/VOLOCHINOV, 2002, p. 113).

Bakhtin caracteriza a enunciação como o produto da interação entre dois indivíduos, mesmo que não haja interlocutor real. Pois, ela é sempre endereçada a alguém, como a um representante médio ao qual pertence o locutor. Toda enunciação tem, então, uma natureza social, mesmo uma fala individual.

O estudioso aclara que cada enunciação é uma fração em uma corrente de comunicação verbal ininterrupta, que comporta outras enunciações. "A enunciação realizada é como uma ilha emergindo de um oceano sem limites, o discurso interior. As dimensões e as formas dessa ilha são determinadas pela situação da enunciação e por seu auditório." (BAKHTIN/VOLOCHINOV, 2002, p. 125).

Já em Estética da criação verbal (2003), Bakhtin utiliza a palavra enunciado no lugar de enunciação. Em nota (BAKHTIN, 2003, p. 261), o tradutor da obra afirma que o filósofo não faz diferenciação entre enunciado e enunciação e emprega a palavra viskázivanie (derivada do infinitivo viskázivat, que significa ato de enunciar) para diferentes formas de comunicação, como o ato de produção do discurso oral, para o discurso escrito, o discurso da cultura, um romance já publicado e absorvido por uma cultura, dentre outras. 
Bakhtin (2003) concebe o enunciado como a unidade real da comunicação discursiva e como um elo na corrente de outros enunciados, ligado aos elos precedentes e também subsequentes.

[...] o enunciado é um elo na cadeia da comunicação discursiva e não pode ser separado dos elos precedentes que o determinam tanto de fora quanto de dentro, gerando nele atitudes responsivas diretas e ressonâncias dialógicas. (BAKHTIN, 2003, p. 300).

De acordo com essa perspectiva, o discurso é sempre responsivo. O falante, assim como o ouvinte do enunciado, é um respondente, tanto no discurso escrito como no falado. Pois, os limites de cada enunciado se dão pela alternância dos sujeitos do discurso, que não se referem necessariamente a indivíduos de carne e osso, como aclarado anteriormente (BAKHTIN, 2003).

Assim, o conceito de oração não pode ser concebido da mesma forma que o de enunciado. Bakhtin (2003) esclarece essa diferença, assinalando que a primeira é a unidade da língua, enquanto o segundo é a unidade da comunicação discursiva. Diferente do enunciado, a oração não é delimitada pela alternância dos sujeitos do discurso, não tem contato imediato com a realidade (situação extraverbal), nem relação imediata com enunciados alheios, e também não dispõe de plenitude semântica e a capacidade de determinar a posição responsiva do outro.

As peculiaridades constitutivas do enunciado, levantadas pelo pensador são: a alternância dos sujeitos do discurso; a conclusibilidade, uma espécie de inteireza do enunciado para que ele seja respondido e a escolha de certo gênero do discurso. Este último item referente aos gêneros será abordado posteriormente nesta dissertação.

$\mathrm{Na}$ visão de Bakhtin (2003), cada enunciado é pleno de variadas atitudes responsivas a outros enunciados, essas reações podem ter diferentes formas: os enunciados dos outros podem ser introduzidos diretamente no contexto do enunciado, podem ser introduzidos só palavras isoladas ou orações, podem ser recontados, podemos nos basear neles etc.

Além disso, acentua que por mais monológico que um enunciado seja, como uma obra científica, não pode deixar de ser também responsiva ao que já foi dito sobre dado objeto. "O enunciado é pleno de tonalidades dialógicas [...]." (BAKHTIN, 2003, p. 298).

É apropriado, neste instante, esclarecer a utilização dos termos enunciado e enunciação para melhor utilizá-los neste trabalho. Beth Brait e Rosineide de Melo 
abordam (2005) que esses conceitos são bastante utilizados nos estudos da linguagem de forma não consensual, pois existem para eles várias definições. Porém, apesar dos sentidos diversos, afirmam que há características comuns que podem ser identificadas nessas definições. As autoras demonstram que em certas teorias o enunciado é tido como frase ou sequências de frase, enquanto em outras teorias ele é concebido como uma unidade de comunicação e significação. (BRAIT; MELO, 2005)

Em Bakhtin, as autoras aclaram que as noções de enunciado e enunciação têm papel central, justamente porque ele concebe a linguagem de um ponto de vista histórico, cultural e social, que envolve a comunicação efetiva, os sujeitos e discursos nela envolvidos. Porém, a concepção de enunciado/enunciação não se encontra acabada em uma determinada obra de Bakhtin. (BRAIT; MELO, 2005)

O sentido desses conceitos vai sendo construído ao longo dos trabalhos de Bakhtin. As autoras citam, entre outras obras, Discurso na vida e discurso na artesobre poética sociológica (1926, s/d), assinada por Volochinov, na qual os termos enunciado, enunciado concreto e enunciação estão relacionados a discurso verbal, a palavra e a evento, respectivamente. (BRAIT; MELO, 2005).

Esse trabalho, de acordo com as autoras, traz a ideia de que o sentido das palavras ou frases acontece e pode ser compreendido porque existe uma situação extraverbal implicada no verbal. "[...] incluindo aí interlocutores que se conhecem, compartilham universos, conhecimentos, pressupostos, sentimentos.” (BRAIT; MELO, 2005, p. 66).

Um enunciado implica, então, muito mais que fatores linguísticos. As estudiosas aclaram que em Discurso na vida e discurso na arte (VOLOCHINOV, 1926, s/d) o enunciado é definido como compreendendo três fatores: o horizonte espacial comum dos interlocutores (a unidade do visível), o conhecimento e a compreensão comum da situação por parte dos interlocutores, e sua avaliação comum dessa situação.

Nessa perspectiva, o enunciado e as particularidades de sua enunciação configuram, necessariamente, o processo interativo, ou seja, o verbal e o não verbal que integram a situação e, ao mesmo tempo, fazem parte de um contexto maior histórico, tanto no que diz respeito a aspectos (enunciados, discursos, sujeitos etc.) que antecedem esse enunciado específico quanto ao que ele projeta adiante [...] (BRAIT; MELO, 2005, p. 67).

Brait e Melo (2005) pontuam que o conceito de enunciado concreto nas obras de Bakhtin pode ser substituído ou fundido com a ideia de palavra, texto, discurso e enunciação concreta, o que não causa problema para a sua compreensão. Já a 
enunciação está situada na fronteira entre a vida e o aspecto verbal do enunciado, ela confere ao elemento linguístico o fator histórico e social.

Desse modo, entendemos o enunciado como o discurso verbal e a enunciação como o evento que dá origem ao enunciado, que extrapola o linguístico em si. A estudiosa Maria Aparecida Baccega (1995) faz um esclarecimento a respeito, situando o discurso nessa relação. "A enunciação é, portanto, o lugar onde "nasce" o discurso, o lugar de onde "brota" o discurso. O enunciado é a manifestação desse discurso, quer seja na modalidade escrita da língua, quer seja na modalidade oral”. (BACCEGA, 1995, p. 53)

Outros conceitos muito utilizados nas análises discursivas que são atribuídos a Bakhtin são os de interdiscursivo, interdiscursividade, interdiscurso, intertexto e intertextualidade. De acordo com José Luiz Fiorin (2012), nas obras de Bakhtin não ocorrem esses termos de forma explícita. Ele verifica, então, como é possível distinguir tais conceitos nas ideias bakhtinianas.

Fiorin (2012) argumenta que o interdiscurso aparece sob o nome de dialogismo em Bakhtin e alerta para a importância de afastar duas leituras errôneas desse conceito: que ele equivale a diálogo, no sentido de interação face a face, e que existem dois dialogismos diferentes, um entre interlocutores e outro entre discursos.

O estudioso explica que não é possível reduzir o dialogismo aos estudos que se faz na Análise da Conversação, porque ele não equivale a diálogo. Além disso, o dialogismo sempre ocorre entre discursos e nessa relação o interlocutor só existe enquanto discurso, já que o real nos é apresentado semioticamente.

Para abordar os conceitos de intertextualidade e interdiscursividade propriamente ditos, Fiorin (2012) recorre às definições que Bakhtin faz de discurso, enunciado e texto. O texto é, assim, a manifestação do enunciado. O enunciado é da ordem do sentido e o texto é do domínio da manifestação. Todo texto é único, individual, irreproduzível e possui um autor. Já o discurso é como uma abstração, uma posição social considerada fora das relações dialógicas, vista como uma identidade.

Assim, Fiorin (2012) argumenta que o termo intertextualidade fica reservado apenas para os casos em que a relação discursiva é materializada em textos; quando a relação dialógica não se manifesta em texto, temos a interdiscursividade.

Fiorin (2012) e Brait e Melo (2005) também chamam a atenção para o fato de o enunciado sempre se dirigir a alguém, que pode ser o interlocutor concreto de um diálogo ou um destinatário presumido, que pode sê-lo pelo autor ou não. Fiorin 
argumenta que todo enunciado, além de um destinatário imediato, que pode ser percebido com maior ou menor consciência, dirige-se a um superdestinatário "[...] cuja compreensão responsiva, idealmente correta, é determinante em sua produção". O superdestinatário assume uma identidade que varia de época para época, de formação social para formação social, de grupo para grupo, que pode ser a ciência a política, a Igreja, por exemplo. (FIORIN, 2012, p.177).

Brait e Melo (2005, p.72) explicam que, na perspectiva bakhtiniana, tentar entender a quem se dirige o enunciado com colocações que indagam "como o locutor percebe e imagina seu destinatário?”, "Qual a força da influência do destinatário sobre o enunciado", por exemplo, ajudam a compreender a composição e o estilo dos enunciados.

No caso da telenovela, podemos tentar responder tais questões de acordo com o reflexo da demanda dos consumidores e telespectadores nas tramas, conforme argumenta Ronsini (2012). A melhoria de renda de uma parte da população, por exemplo, incita os profissionais de telenovela a representá-la, como ocorreu na telenovela Duas Caras (2007-2008), que representou a favela e seus moradores.

Podemos estender tal fato para a representação da "nova classe média" nas tramas escolhidas por este trabalho. Os destinatários imediatos poderiam ser considerados, no caso, os consumidores "da nova classe C", que são representados na telenovela via personagens. Além disso, a telenovela tem por finalidade agradar a audiência e fazer sucesso, isso faz com que os escritores escrevam focados no gosto do público e não em outros propósitos (RONSINI, 2012). Assim, o superdestinatário poderia ser o próprio mercado e suas lógicas que encontram respaldo nos próprios personagens que representam uma "nova classe C" idealizada pelo mercado e pelo sistema econômico.

Desse modo, no que se refere às teorias de Bakhtin, tentamos mostrar as importantes contribuições do autor no que diz respeito à concepção social da linguagem, bem como para a análise discursiva, com conceitos trabalhados posteriormente por outros autores.

Bakhtin é considerado, inclusive, como um dos autores responsáveis pela base para a formulação da Análise do Discurso. De acordo com Maria do Rosário Gregolin (2012), o solo epistemológico na Análise do Discurso foi fertilizado pela interpretação que os autores Pêcheux, Foucault e Bakhtin fizeram da "tríplice aliança", isto é a releitura das teorias de Saussure, Marx e Freud. 
Gregolin (2006) explica que das releituras desses três pensadores surgiram novos conceitos de sujeito, história e língua, que deram origem ao objeto discurso propriamente dito, baseado em um novo estruturalismo, um novo marxismo e um novo sujeito.

Essa “Tríplice Aliança” trouxe o simbólico, o significante, mais especificamente a língua, no contexto da problemática sobre o homem, marcada até então pela dualidade biológica e social (GREGOLIN, 2006). Desse modo, houve a inserção da linguagem no âmbito social do ser humano ao relacionar história, sujeito e língua. É justamente passando por essas três esferas que a Análise do Discurso toma forma.

Helena Nagamine Brandão aclara que a partir da Análise do Discurso, a linguagem passa a ser um fenômeno que deve ser estudado não só em relação ao seu fenômeno interno, mas também enquanto formação ideológica (BRANDÃO, 2002), conforme expusemos coma as teorias de Bakhtin.

Brandão (2012) nos coloca três questões importantes que circulam entre as diferentes tendências da Análise do Discurso, são elas: trabalhar no nível do discurso é atuar no nível linguístico e extralinguístico; o discurso diz respeito a enunciados concretos e não a abstrações gramaticais; as partes envolvidas no discurso devem dominar a língua na qual o discurso é proferido.

A autora qualifica três conceitos básicos para uma análise discursiva: as condições de produção, a formação ideológica e a formação discursiva. A estudiosa explica que as condições de produção dizem respeito à situação de enunciação e também ao contexto mais amplo sócio-histórico-ideológico. Já as formações ideológicas são os conjuntos de atitudes e representações relacionadas às posições de classe social, política e econômica de onde se fala ou escreve, e tem a ver também com as relações de poder. As formações discursivas, por sua vez, representam na linguagem as formações ideológicas, sendo que toda formação discursiva é atravessada por outras. (BRANDÃO, 2012)

A autora mostra que a palavra enquanto polissêmica e plurissignificativa deve ter seu sentido desambiguizado de acordo com o levantamento das condições de produção do discurso no sentido estrito do momento da enunciação e também no sentido amplo das condições sociais, históricas e ideológicas. Neste ponto está o caráter extralinguístico que sempre deve ser levado em conta. (BRANDÃO, 2012).

Outros conceitos levantados pela autora que são pertinentes para uma análise discursiva são a interdiscursividade e a heterogeneidade, que pressupõem que uma 
formação discursiva está sempre em interação com outras e os discursos se relacionam, podendo conflitar-se ou assemelhar-se nessas formações (BRANDÃO, 2012).

A esse respeito, o teórico da vertente da Análise do Discurso Francesa, Dominique Maingueneau, nos traz importantes apontamentos na obra Novas Tendências em Análise do Discurso (1989). Nela, o autor aborda o estudo do teórico Jean-Jacques Courtine (2009) sobre o discurso comunista dirigido a cristãos e retoma os estudos de Bakhtin para abordar a dialogia e relação com o outro.

Com base no trabalho desenvolvido por Jacqueline Authier-Revuz (1982) e, posteriormente, por Courtine (2009), Maingueneau (1989) demonstra que o fechamento de uma formação discursiva é aberto, instável e heterogêneo. O discurso, assim, não é constituído como uma unidade fechada, mas se dá justamente nas relações com outros discursos, no interdiscurso.

De fato, uma formação discursiva não deve ser concebida como um bloco compacto que se oporia a outros (o discurso comunista contra o discurso democrata-cristão, por exemplo), mas como uma realidade "heterogênea por si mesma" [...] (MAINGUENEAU, 1989, p. 112).

$\mathrm{O}$ autor acredita em um enunciado como pertencente a uma rede abrangente, na qual cada um deles estabelece elos com seu contexto imediato e também relações com outros enunciados pertencentes à mesma formação discursiva, encontrando-se em uma rede interdiscursiva. Porém, a aparente sincronia e linearidade da formação discursiva acarreta o apagamento do interdiscurso no discurso.

Afirma ainda que toda formação discursiva é associada, de maneira geral, a uma memória discursiva, constituída de formulações que repetem, recusam e transformam outras formulações. Toda formulação estaria, então, na interseção de dois eixos, o vertical do domínio da memória, e o horizontal da linearidade do discurso, que oculta o primeiro eixo "[...] já que o sujeito enunciador é produzido como se interiorizasse de forma ilusória o pré-construído que sua formação discursiva impõe." (MAINGUENEAU, 1989, p. 115).

Assim, a interdiscursividade, ou dialogia, é constitutiva do discurso. Além disso, o aspecto histórico e social do discurso faz dele dialético, ou seja, um produto dado da sociedade e também um produtor de transformações, conforme aponta os estudos de Bakhtin e demonstra a teórica Maria Aparecida Baccega (1995). 
"Essa cultura "pronta" nos é transmitida pela linguagem, principalmente a verbal, através da palavra. $\mathrm{O}$ fato de podermos construir o novo é uma possibilidade que também nos é dada sobretudo pela palavra.” (BACCEGA, 1995, p. 28).

A autora explica que a mediação entre o homem e a realidade objetiva é exercida pela linguagem, sobretudo pela verbal, por meio da palavra, que assume o seu significado em discursos, assim como propõem os autores marxistas - Vigotski (2005), Schaff (1974) e Leontiev (2004) - que versam sobre a linguagem, a consciência e o pensamento humanos.

De modo similar, os autores expostos que abordam a Análise do Discurso Francesa aclaram sobre o caráter metalinguístico do discurso, a necessidade de olhar para os enunciados, levando em consideração a sua condição de produção e formação ideológica, sobretudo, no que diz respeito às formações discursivas circulantes nas mídias como estudam Maingueneau (2004) e Charaudeau (2012).

Essas colocações somam-se ao discurso enquanto uma prática social como sustenta a ADC. Para Fairclough e Wodak (2000), descrever o discurso como prática social sugere uma relação dialética entre o um acontecimento discursivo particular e as situações institucionais e estruturas sociais que o circundam.

A ADC é uma teoria interdisciplinar que se ocupa dos processos e movimentos sociais e políticos que marcam a sociedade. Trata-se de um paradigma científico comprometido socialmente, cujo objetivo principal é manifestar as relações de poder (FAIRCLOUGH; WODAK, 2000). Além disso, a ADC também postula uma metodologia de análise discursiva. Por isso, acreditamos que se trata de uma teoria pertinente de ser considerada para a proposta analítica deste trabalho.

\subsection{DISCURSO COMO PRÁTICA SOCIAL, SIGNIFICAÇÃO REPRESENTACIONAL, IDENTIFICACIONAL E ACIONAL}

Em Discurso e mudança social (2001), Fairclough, um dos expoentes da ADC, expõe o desenvolvimento de uma abordagem de análise linguística para investigar as mudanças que ocorrem na linguagem, em uma tentativa de reunir a análise linguística e a teoria social. 
$\mathrm{O}$ autor acredita ter havido transformações no funcionamento social da linguagem, dentre as quais ele destaca o movimento de extensão do mercado a novas áreas da vida social, como a educação, e as transformações na indústria na produção pós-fordista, que acarretaram transformações nas práticas discursivas.

Houve, assim, um processo de relexicalização de atividades e relações. Por exemplo, no caso da educação, no lugar de aprendizes usa-se "clientes" ou “consumidores”, já os funcionários pós-fordistas, inseridos nas relações ditas flexíveis e com relações de autoridade menos marcadas, são "empreendedores", "automotivados" e "autodirecionados" (FAIRCLOUGH, 2001, p. 25-26).

O estudioso defende que o uso linguístico está assumindo uma importância maior como meio de produção e controle social no local de trabalho, e que o destaque cada vez maior para o discurso nas transformações sociais relaciona-se com uma preocupação em controlar o discurso, no sentido de causar mudanças nas práticas discursivas para uma mudança social e cultural.

O objetivo de Fairclough (2001) é realizar uma abordagem para a análise discursiva que sirva como método de investigação para tais mudanças. Para isso, ele desenvolve uma concepção tridimensional do discurso - que envolve texto, prática discursiva e prática social - com o intuito de avaliar as relações entre mudanças discursiva e social e relacionar propriedades de textos às questões sociais dos eventos discursivos.

Para o autor, o discurso é um modo de ação sobre o mundo e sobre as pessoas, uma prática social não só de representação do mundo, mas também de significação dele. Além disso, considera o discurso em uma relação dialética com a estrutura social, assim como a estrutura social e a prática social, pois a primeira é uma condição e um efeito da segunda.

Segundo o teórico, o discurso contribui para a construção de identidades sociais e posições de sujeito, para construir relações sociais entre as pessoas e para a construção de sistemas de conhecimento e crença. Essas três funções são denominadas pelo autor, respectivamente, como identitária, relacional e ideacional.

A função identitária está relacionada com os modos pelos quais as identidades são estabelecidas no discurso; a relacional tem a ver com a forma como as relações sociais entre os participantes do discurso são representadas e negociadas; e a função ideacional se refere aos modos pelos quais os textos significam o mundo, seus processos, entidades e relações. (FAIRCLOUGH, 2001) 
Tais definições passam por transformações ao longo dos estudos deste teórico e são redefinidas como significações identificacional, acional e representacional, como apontam comentaristas da obra de Fairclough:

O significado acional focaliza o texto como modo de (inter) relação em eventos sociais, aproxima-se da função relacional, pois a ação legitima/questiona relações sociais; o significado representacional enfatiza a representação de aspectos do mundo - físico, mental, social - em textos, aproximando-se da função ideacional; o significado identificacional refere-se à construção e à negociação de identidades no discurso, relacionado-se à função identitária (RESENDE; RAMALHO, 2005, p. 40).

Fairclough (2001) explana que a análise na dimensão da prática discursiva está centrada no conceito de intertextualidade, que será abordada mais adiante, e a formulação da análise da prática social está calcada nos conceitos de ideologia e hegemonia. A abordagem de mudança discursiva combina a concepção de texto e prática discursiva com base também na intertextualidade.

Já a dimensão textual é o que torna a prática discursiva especificamente discursiva. O texto, assim como a prática social (política, ideológica etc.), é uma dimensão do evento discursivo, assim como a prática discursiva é uma forma particular da prática social, em sua elaboração, circulação e consumo (FAIRCLOUGH, 2001).

A preocupação central, segundo o teórico, é estabelecer conexões explanatórias entre os modos de organização e interpretação textual e a natureza da prática social, em sua relação com as estruturas e as lutas sociais. Os textos são como traços e pistas dos processos de produção e interpretação, por isso, sozinhos não podem reconstruir o processo.

Assim, o autor acredita que uma análise da prática discursiva deve combinar uma microanálise e uma macroanálise. A primeira se relaciona ao texto e fornece evidências para a macroanálise.

É devido a sua inter-relação que a dimensão da prática discursiva em minha teoria tridimensional pode mediar a relação entre as dimensões da prática social e do texto: é a natureza da prática social que determina os macroprocessos da prática discursiva e são os microprocessos que moldam o texto. (FAIRCLOUGH, 2001, p. 115).

Para versar sobre o discurso como prática social e que, portanto, pode ser compreendido como prática comunicacional de interação, Fairclough aborda a ideologia e a hegemonia. As ideologias são para ele significações/construções da realidade que 
são construídas em várias dimensões das práticas discursivas e que contribuem para a produção, a reprodução ou transformação das relações de dominação. Ele considera a ideologia tanto uma propriedade de estruturas como de eventos. Além disso, ela possui um caráter dialético, na medida em que os sujeitos são posicionados ideologicamente, mas também são capazes de agir criativamente (FAIRCLOUGH, 2001).

Para explorar o conceito de hegemonia, por sua vez, o autor utiliza a concepção do teórico Antônio Gramsci (1971), que a considera um equilíbrio instável, uma construção de alianças e não simplesmente uma dominação de classes subalternas. Assim, os eventos discursivos são capazes de influenciar a hegemonia constituída, uma vez que esta é instável e não definitiva. A hegemonia é explicitada pelo estudioso como um foco de constante luta sobre pontos de maior instabilidade entre classes e blocos para construir, manter ou romper relações de dominação (FAIRCLOUGH, 2001).

De acordo com esse panorama, o autor utiliza o conceito de intertextualidade como uma forma de apontar para a produtividade dos textos, para o modo como eles podem transformar textos anteriores e reestruturar convenções para gerar novos textos; produtividade essa limitada e condicionada socialmente pelas relações de poder, onde se configura a hegemonia.

Além disso, a intertextualidade é para Fairclough (2001), geradora de ambivalências, pois a superfície de um texto pode ser determinada por vários outros textos que entram em sua composição e diferentes sentidos podem coexistir.

Para responder a questão sobre como concebemos as convenções e as normas discursivas por trás dos eventos discursivos, o estudioso traz o conceito de interdiscurso da Análise do Discurso Francesa, já comentado neste trabalho, que se trata para ele de uma "complexa configuração interdependente de formações discursivas" que tem primazia sobre as partes. "[...] interdiscurso é a entidade estrutural que subjaz aos eventos discursivos [...]" (FAIRCLOUGH, 2001, p. 95).

É conveniente esclarecer o uso dos termos interdiscursividade e intertextualidade na obra do autor. Fairclough (2001, p. 136-137) utiliza intertextualidade manifesta quando outros textos estão explicitamente presentes no texto que está sendo analisado, e intertextualidade constitutiva (ou interdiscursividade) para a configuração de convenções discursivas na produção do texto em questão. Porém, afirma usar o termo intertextualidade para os dois casos, de forma geral, em algumas circunstâncias.

$\mathrm{O}$ autor utiliza o conceito de intertextualidade baseado em Bakhtin via Julia Kristeva, estudiosa que conferiu tal conceito ao filósofo russo. Conforme comentado 
anteriormente, com base no autor José Luiz Fiorin (2012), Bakhtin nunca utilizou o termo intertextualidade de forma explícita, o conceito pode ser deduzido em sua obra como uma relação entre textos, e quando a relação não se dá em textos, temos a interdiscursividade. Assim, entendemos que, muitas vezes, a intertextualidade de Fairclough se refere ao que compreendemos por interdiscursividade, já que o próprio autor afirma usar intertextualidade para ambos os casos.

Desse modo, entendemos que o discurso como prática social é concebido em dialogia (de forma interdiscursiva) com as ideologias e hegemonias. A prática discursiva, que engloba a produção discursiva, pode ser relacionada à enunciação, pois como esclarece Brandão (2012), as condições de produção se referem à situação de enunciação e também ao contexto mais amplo. O texto, assim, se relaciona dialogicamente com a prática discursiva e com a prática social. As relações dialógicas podem ser intertextuais quando se referem a textos ou interdiscursivas quando se referem a discursos, conforme pontua Fiorin (2012).

No caso da telenovela, o seu discurso se relaciona dialogicamente com o que vem sendo chamada a representação de uma "nova classe C" em jornais e revistas, o que tangencia, na prática social, a visão economicista, a ideologia do desempenho e meritocrática comentadas por Souza (2012) e Ronsini (2012). Cabe a este trabalho identificar no discurso das cenas selecionadas os indícios dessas práticas.

Para tanto, acreditamos serem frutíferas as significações do discurso consideradas por Norman Fairclough, levantadas anteriormente por Resende e Ramalho (2005), a saber: a significação acional, identificacional e representacional, para analisar a representação de sentidos de classe sociais nos discursos, mediante o levantamento das identidades discursivas. Essa perspectiva busca operar a verificação sociotécnica discursiva do dispositivo telenovela ${ }^{8}$ na midiatização dos consumos e dos sentidos da "nova classe C".

\footnotetext{
${ }^{8}$ A palavra dispositivo é empregada aqui do modo teorizado por Trindade e Perez (2013) que utilizam os conceitos de Foucault (2012) e Agamben (2010). Foucault (2012) entende o dispositivo, dentre outros aspectos, como um tipo de formação em determinado momento histórico que teve como função principal responder a uma certa urgência. O dispositivo, em sua visão, tem uma função estratégica dominante. Agamben (2010), por sua vez, atualiza a discussão sobre dispositivo de Foucault e o define como qualquer coisa que tenha de algum modo a capacidade de capturar, orientar, determinar, interceptar, modelar, controlar e assegurar os gestos, as condutas, as opiniões e os discursos dos seres humanos. Sua concepção engloba não só as instituições que se conectam com o poder de forma mais evidente, como as escolas e as fábricas, mas também objetos como a caneta e o celular, áreas do conhecimento como a literatura, a filosofia e até a própria linguagem, por exemplo.
} 
Resende e Ramalho (2005), é conveniente destacar, argumentam que em obra posterior à Discurso e mudança social (2001), Fairclough faz uma correspondência entre ação e gêneros, representação e discurso e identificação e estilos.

Fairclough explica que discursos (no significado representacional) são concretizados em gêneros (no significado acional) e inculcados em estilos (no significado identificacional), e que ações e identidades (incluindo gêneros e estilos) são representadas em discursos. (RESENDE; RAMALHO, 2005, p. 43).

Em Discurso e mudança social, Fairclough (2001) aborda os gêneros, estilos e discursos em uma perspectiva interdiscursiva. $\mathrm{O}$ autor utiliza a visão bakhtiniana para abordar gênero, que fornece a visão tanto da limitação social das práticas sociais pelas convenções como da potencialidade de mudança e criatividade.

Fairclough utiliza o termo gênero para um conjunto de convenções relativamente estável que é associado a um tipo de atividade socialmente aprovado, como uma entrevista de emprego ou a compra de um produto em uma loja. $\mathrm{O}$ gênero implica um tipo particular de texto e também processos particulares de produção, distribuição e consumo de textos.

Já o estilo, segundo o estudioso, varia de acordo com o que ele chama de tenor (tipo de relação que existe entre os participantes na interação), com o modo (se os textos são escritos ou falados, por exemplo) e com o modo retórico (argumentativo, descritivo ou expositivo).

O discurso, na visão de Fairclough (2001), é o mais autônomo dos elementos, trata-se de um modo particular de construir um assunto ou área de conhecimento. Ele pode ser associado a uma variedade de gêneros, como, por exemplo, o discurso médico que se relaciona com artigos científicos, conferências e consultas, mas também pode estar presente em conversação, entrevistas e poemas.

Sobre o estilo, o autor nos dá o exemplo do modo retórico de uma reportagem, cujo fornecedor de notícias é construído como a fonte de conhecimento e informação, o leitor como um ser passivo e a reportagem consiste em asserções categóricas autoritárias. O estilo envolve, assim, o texto, o modo como um discurso é transmitido, o tom que ele adquire.

Cabe-nos aqui levantar o que o autor Bakhtin (2003) aborda a respeito do gênero e do estilo. De acordo com o filósofo da linguagem, o emprego da língua efetua-se em forma de enunciados, que refletem as condições específicas e as finalidades de cada 
campo da atividade humana, pelo seu conteúdo temático, pelo estilo e por sua construção composicional. Esses três elementos, segundo o pensador, estão ligados no todo do enunciado e são determinados pela especificidade de um determinado campo da comunicação. "Evidentemente cada enunciado particular é individual, mas cada campo de utilização da língua elabora seus tipos relativamente estáveis de enunciados, aos quais denominas gêneros do discurso". (BAKHTIN, 2003, p. 262).

Bakhtin (2003) frisa que a riqueza e a diversidade dos gêneros do discurso são infinitas; além disso, são heterogêneos. Existem os gêneros discursivos primários (simples), formados nas condições da comunicação discursiva imediata; e os gêneros secundários (complexos) formados nas condições de um convívio cultural mais complexo, por exemplo, os romances, dramas, pesquisas cientificas, etc.. Os gêneros primários são integrados pelos complexos.

$\mathrm{Na}$ visão do autor, a maioria dos gêneros literários é constituída de gêneros secundários, complexos, que são formados por diferentes gêneros primários transformados, como réplicas de diálogo, relatos cotidianos, cartas, diários, entre outros.

Os estilos, por sua vez, estão sempre atrelados ao gênero do discurso, mas podem ser individuais. Enquanto o gênero, ao contrário, está menos propenso ao reflexo da individualidade.

Todo enunciado - oral e escrito, primário e secundário e também em qualquer campo da comunicação discursiva [...] pode refletir a individualidade do falante (ou de quem escreve), isto é, pode ter estilo individual. Entretanto, nem todos os gêneros são igualmente propícios a tal reflexo da individualidade do falante na linguagem do enunciado, ou seja, ao estilo individual. (BAKHTIN, 2003, p. 265).

De acordo com o estudioso, os enunciados e os gêneros discursivos são correias de transmissão entre a história da sociedade e a história da linguagem. Os novos fenômenos (fonéticos, léxicos, gramaticais) só se integram ao sistema da língua depois de um longo caminho de experimentação e elaboração de gêneros e estilos.

$\mathrm{O}$ autor explica que falamos por gêneros sem perceber, pois as formas de língua e os gêneros chegam a nós em conjunto e vinculados. Aprendemos a falar construindo enunciados. "Falamos apenas através de determinados gêneros do discurso, isto é, todos os nossos enunciados possuem formas relativamente estáveis e típicas de construção do todo." (BAKHTIN, 2003, p. 282).

A diversidade dos gêneros se dá pelas diferenças situacionais, pela posição social e relações pessoais entre os participantes da comunicação. Desse modo, há formas 
rigorosas e oficiais, enquanto há outras mais familiares, em diferentes graus (BAKHTIN, 2003).

É conveniente ressaltar que o gênero comporta tanto o aspecto normativo quanto o criativo. $\mathrm{O}$ autor explica que os gêneros dos discursos são mais mutáveis e flexíveis em relação às formas da língua, porém para o indivíduo os gêneros têm significado normativo, pois são dados a ele e não criados por ele.

A estudiosa Irene Machado (2005) explica que a partir dos estudos de Bakhtin foi possível mudar as rotas das investigações científicas sobre o gênero, pois ele considera os gêneros no dialogismo do processo comunicativo, diferente da consagrada classificação aristotélica dos gêneros na literatura. Bakhtin enxerga a necessidade de um exame não só da retórica, mas, sobretudo, das práticas prosaicas.

Machado (2005) argumenta que os gêneros da prosa, diferente dos gêneros poéticos, são contaminações de formas pluriestilísticas como a paródia, a estilização, a linguagem carnavalizada e a heteroglossia.

A prosa corresponde, assim, àquelas instâncias da comunicação em que os discursos heterogêneos entre si são empregados ainda que não haja nenhuma regra combinatória aparente. Por ser fenômeno de emergência na linguagem, a prosa não nasceu pronta: ela continua se fazendo, desde o seu surgimento, graças à dinâmica dos gêneros discursivos. (MACHADO, 2005, p. 155).

A autora afirma que os gêneros discursivos são formas comunicativas que não são adquiridos em manuais, mas nos processos interativos. O gênero linguístico então, por essa perspectiva, não tem o caráter de uma forma linguística, e sim de uma forma enunciativa, que depende do contexto comunicativo e cultural.

Machado (2005) explica ainda que os gêneros, na concepção de Bakhtin, devem ser dimensionados como manifestação da cultura, dentro da dimensão espaço-temporal, pois ele entende que as obras vivem em um grande tempo e são capazes de romper os limites do presente onde surgem, reportando-se ao passado e ao futuro.

Desse modo, com as transformações na comunicação ao longo do tempo, a estudiosa aponta para a possibilidade de um redimensionamento do alcance das formulações de Bakhtin sobre os gêneros para os estudos dos discursos na prosa comunicativa contemporânea, como nos filmes, programas de televisão e formatos digitais. Pois, ao refletir sobre o diálogo como forma elementar da comunicação, Bakhtin valorizou esferas da linguagem que não estão limitadas a um único meio, 
abrindo caminho para outras realizações, como os meios de comunicação de massa e as mídias digitais. (MACHADO, 2005).

Essas características da teoria bakhtiniana sobre o gênero estão presentes em Questões de Literatura e Estética (a teoria do romance) (2010), obra na qual Bakhtin critica os estudos estilísticos tradicionais que não levam em consideração a combinação de linguagens e estilos, presente no romance, por exemplo.

O filósofo da linguagem enfatiza a orientação dialógica dos gêneros prosaicos ao contrapô-los em suas colocações ao gênero poético. Os gêneros prosaicos abarcam a prosa romanesca que é carregada de plurilinguismos e pluridiscursos.

Bakhtin (2010) argumenta que a poética antiga de Aristóteles, por exemplo, serve à tarefa de centralização e unificação das línguas europeias, da língua nacional, cultural e poética, em um movimento que contribui para o que ele denomina de forças centrípetas. Porém, existem também as forças centrífugas da língua comum e da enunciação concreta que coexistem com aquelas centralizadoras.

Diferente dos gêneros poéticos que se desenvolvem na corrente das forças centrípetas que unificam e centralizam, o romance e os gêneros literários e prosaicos constituíram-se historicamente na corrente das forças descentralizadoras, explica Bakhtin (2010).

[...] enquanto a poesia, nas altas camadas sócio-ideológicas oficiais, resolvia o problema da centralização cultural, nacional e política do mundo verbal-ideológico, por baixo, nos palcos das barracas de feira, soava um discurso jogralesco, que arremedava todas as "línguas" $\mathrm{e}$ dialetos, desenvolvia a literatura das fábulas e das soties, das canções de rua, dos provérbios, das anedotas. Nesses palcos não havia nenhum daqueles centros linguísticos donde o jogo vivo se realizava nas "línguas" dos poetas, dos sábios, dos monges, dos cavaleiros, etc., e nenhum aspecto seu era verdadeiro e indiscutível. (BAKHTIN, 2010, p. 83)

O conjunto romanesco é composto, segundo Bakhtin (2010), pela narrativa direta e literária do autor; pela estilização de diversas formas da narrativa tradicional oral e da narrativa escrita semiliterária tradicional, como cartas e diários; por várias formas literárias que estão fora do discurso literário do autor, como escritos morais, filosóficos, científicos, declamações retóricas etc.; e os discursos dos personagens estilisticamente individualizados.

De acordo com as teorias de Bakhtin (2003), podemos considerar a telenovela um gênero secundário (complexo) constituído por gêneros primários, como o da conversação informal. Ademais, considerando que os gêneros se constituem em relação 
ao outro, dialogicamente (BAKHTIN, 2010) acredita-se que é dessa forma que eles devem ser analisados. É possível estender, inclusive, as concepções bakhtinianas da prosa romanesca para o gênero da telenovela.

Dominique Maingueneau também aborda os gêneros em seu livro Análise de Textos de Comunicação (2004). Para o autor, os gêneros são categorias de discurso, dispositivos de comunicação que aparecem em determinadas condições sócio-históricas.

Na visão do autor, os gêneros pertencem a diversos tipos de discurso associados a vastos setores de atividade social. Por exemplo, o talk show, constitui um gênero do discurso dentro do tipo de discurso televisivo, que faz parte, por sua vez, de um conjunto maior do discurso midiático (MAINGUENEAU, 2004).

Dentre as utilidades do gênero do discurso, o autor destaca assegurar a comunicação, de modo a evitar a violência, o mal entendido e a angústia de alguns dos participantes da comunicação, pois as normas dos gêneros discursivos indicam o que deve ser esperado de determinado discurso, tanto da parte de quem fala como da de quem recebe o discurso.

Maingueneau (2004) também aclara que os gêneros do discurso atendem a determinada finalidade, por exemplo, a publicidade visa seduzir, enquanto uma dissertação precisa mostrar aptidões a fïm de obter uma avaliação. Eles também determinam de quem parte e a quem se endereça o discurso, como um professor que fala a um aluno. Além disso, os gêneros implicam um lugar e uma temporalidade que podem variar. No caso do lugar, podemos exemplificar a reza de uma missa em uma igreja e quanto à temporalidade temos o exemplo da duração de um telejornal, a periodicidade de um curso ou a validade de uma revista.

Ademais, o suporte material dos gêneros do discurso também é importante.

Uma modificação do suporte material de um texto modifica radicalmente um gênero de discurso: um debate político pela televisão é um gênero de discurso totalmente diferente de um debate em uma sala para um público exclusivamente formado pelos ouvintes presentes. (MAINGUENEAU, 2004, p. 68).

Desse modo, entendemos que o gênero como uma convenção faz com que se espere do discurso algo mais ou menos determinado. Mas, por outro lado, os gêneros não são imutáveis, eles também mudam.

No caso da telenovela, podemos dizer que há a finalidade de entretenimento e as características de compensação e provação-pacificação da narrativa folhetinesca 
comentadas no primeiro capítulo, segundo o teórico Martín-Barbero (2009). Também levantamos anteriormente os dispositivos do folhetim, abordados pelo autor, de composição tipográfica (letras grandes, claras e espacejadas), de fragmentação, os dispositivos de sedução (duração e suspense) e os de identificação. No folhetim eletrônico essas características foram adaptadas para o suporte televisivo, que proporcionou outra dimensão ao gênero, sobretudo no Brasil, conforme argumentado no primeiro capítulo.

De acordo com as estudiosas Motter e Mungioli (2007-2008) a matriz genérica telenovela atua não só como um mapa ou modelo prescritivo, mas também como modelo interpretativo de um mundo construído à semelhança da realidade.

As autoras argumentam que pensar a telenovela como gênero é mais que pensá-la como um produto de uma emissora televisiva, resultado da inspiração de um roteirista ou como um programa de televisão “[...] significa analisá-la dentro da complexidade da teia discursiva que constitui os sujeitos da comunicação situados num contexto social e cultural marcado pela comunicação de massa". (MOTTER; MUNGIOLI, 2007-2008, p. $64)$.

Isto posto a respeito dos gêneros discursivos, trataremos agora dos estilos, que de acordo com Resende e Ramalho (2005) constituem o aspecto discursivo de identidades, relacionam-se à identificação de atores sociais em textos. Eles também podem refletir a individualidade do falante, conforme pontua Bakhtin (2003).“É justamente a individualidade do locutor que é reconhecida como o fator que forma o estilo e que transforma o fenômeno linguístico e verbal em unidade linguística" (BAKHTIN, 2010, p. 75).

De acordo com a linguista Norma Discini (2006, p. 1544), o estilo é como um modo de presença de sujeito na enunciação. Ele pode ser entendido como determinado tom de voz e caráter de um sujeito "[...] depreensíveis ambos de uma tonalidade de discursos: um ethos".

Maingueneau (2004) aborda o conceito, retomado das teorias aristotélicas de ethos. Trata-se do orador, cuja postura extrapola o texto em si e situa em seu meio circundante a imagem que este orador quer construir sobre si mesmo frente a um auditório, desencadeando possíveis reações. Para o autor, o ethos é como um fiador do que é dito, uma espécie de voz que não está explícita no enunciado e por isso mesmo é eficaz. O ethos pode ser construído pelo público a partir de um conjunto de indícios. 
Ao fiador, cuja figura o leitor deve construir a partir de indícios textuais de diversas ordens, são atribuídos um caráter e uma corporalidade, cujo grau de precisão varia segundo os textos. $\mathrm{O}$ "caráter" corresponde a uma gama de traços psicológicos. Já a "corporalidade" corresponde a uma compleição corporal, mas também a uma maneira de se vestir e de se movimentar no espaço social. (MAINGUENEAU, 2004, p. 98-99).

Além disso, é possível considerar que vários ethé podem ser encontrados em um mesmo texto, dada a complexidade discursiva, sua instabilidade e interdiscursividade constitutiva.

Maingueneau (2008) expõe também que o ethos está relacionado ao ato de enunciação, mas pode ser construído de diversas formas. No entanto, existem os seguintes princípios mínimos comuns a todas as construções: o ethos é uma noção discursiva, se constrói por meio do discurso e não é uma imagem do locutor exterior à sua fala; trata-se de um processo interativo de influência sobre o outro; é uma noção fundamentalmente híbrida (sociodiscursiva) e não pode ser apreendida fora de uma situação de comunicação.

Fairclough (2001), por sua vez, expõe que a questão do ethos é intertextual (ou interdiscursiva no nosso entendimento). A análise do ethos atende a perguntas como "[...] que modelos de outros gêneros e tipos de discurso são empregados para constituir a subjetividade (identidade social do 'eu') dos participantes de interações? [...]" (FAIRCLOUGH, 2001, p. 207).

Segundo o autor, o ethos pode ser considerado como parte de um processo maior, no qual o lugar e o tempo de uma interação e seu conjunto de participantes, assim como o ethos dos participantes, são constituídos pela projeção de ligações intertextuais (ou interdiscursivas).

Outro dado importante abordado por Fairclough (2001) é que o ethos é manifestado pelo corpo inteiro, não só pela voz, mas também pelo efeito cumulativo da disposição corporal total, o modo de sentar-se, a expressão facial, os movimentos, as respostas físicas etc. $\mathrm{O}$ autor exibe o exemplo do ethos médico, que é sinalizado pelo modo dos médicos falarem, pelos movimentos realizados, formas de responder fisicamente ao que é dito, se chegam perto dos pacientes ou mantêm distância, por exemplo. "O conceito de ethos constitui um ponto no qual podemos unir as diversas

\footnotetext{
${ }^{9}$ Plural de ethos.
} 
características, não apenas do discurso, mas também do comportamento em geral, que levam a construir uma versão particular do “eu"”. (FAIRCLOUGH, 2001, p. 209).

Assim, com a aplicação do conceito de ethos, pretendemos levantar o significado identificacional, possibilitado também pela análise textual, e dos elementos pertencentes ao gênero. A significação representacional, por sua vez, compreende o discurso em si, as ideologias nele presentes. Em nosso caso, trata-se da representação do consumo e do sentido de classe social, que emergirá com a análise das duas outras etapas explicitadas.

É pertinente esclarecer que a relação entre as três significações é dialética, elas não estão isoladas. "[...] a distinção entre os três aspectos é analítica, mas não exclui a fluidez e a interiorização entre eles.” (RESENDE; RAMALHO, 2005, p. 34).

Ademais, acreditamos que a mescla da ADC com elementos da Análise do Discurso Francesa (AD) pode nos fornecer um caminho pertinente de análise para a midiatização do consumo e do sentido de classes sociais e suas nuanças.

\subsection{PROTOCOLO DE ANÁLISE}

O protocolo de análise da midiatização do consumo e do sentido de classe social em Avenida Brasil e Cheias de Charme levará em consideração o discurso de forma dialética e dialógica com a prática social. Entendemos as formações discursivas de maneira heterogênea, se comunicando umas com as outras, bem como seus enunciados, conforme postulou Bakhtin (2003) e teóricos da Análise do Discurso Francesa, como Maingueneau (1989).

O discurso enquanto prática social se relaciona de forma interdiscursiva com outras instâncias da prática social e da estrutura social, suas ideologias, hegemonias e relações de poder. Ademais, a prática discursiva também compreende o conceito de enunciação, no que se refere às condições de produção que dão vida ao enunciado.

Assim o enunciado, no nível textual, enquanto parte da prática discursiva pode revelar os indícios dessas relações. Utilizaremos, então, a correspondência entre significação acional e gêneros, representação e discurso e identificação e estilos (RESENDE; RAMALHO, 2005), como foi exposto anteriormente. Vale lembrar que as significações se relacionam entre si e não são estanques. 
Desse modo, o significado representacional, que gera sistemas de conhecimento e se relaciona ao discurso, nos será possibilitado mediante a análise do significado identificacional - no qual levantaremos o ethos, que pode ser apreendido pelo estilo do texto - e a análise do significado acional, no qual se encontram os elementos do gênero, e que constituem aspectos especificamente discursivos de maneiras de ação (RESENDE; RAMALHO, 2005).

É pertinente destacar que na análise consideraremos aspectos da narrativa das telenovelas como parte da enunciação que deu origem ao enunciado em questão. Por isso, primeiramente, faremos uma contextualização sobre a narrativa, os principais acontecimentos e personagens. Em seguida, partiremos para a cena analisada, descrevendo-a, com transcrição dos diálogos, para depois partir para a análise propriamente dita, como esclarece as etapas a seguir:

- Levantamento de aspectos da prática discursiva, no que se refere à condição de produção da telenovela, a enunciação: Descrição geral das telenovelas Avenida Brasil e Cheias de Charme e suas narrativas, principais personagens e acontecimentos.

- Descrição geral das cenas escolhidas, transcrição dos diálogos ${ }^{10}$.

- Análise textual/dos enunciados selecionados e descritos, de acordo com as significações e associações realizadas por Fairclough: correspondência entre significação acional e gêneros, representação e discurso e identificação e estilos (RESENDE; RAMALHO, 2005).

De forma resumida, as significações serão aplicadas da seguinte forma:

- Significação acional: serão analisados aspectos atrelados ao gênero discursivo, ou seja, a estrutura da cena, a linguagem verbal e audiovisual, a interação entre os personagens e, quando se mostrar relevante, a composição do cenário e as roupas dos personagens em questão.

\footnotetext{
${ }^{10}$ É preciso explicar que a transcrição dos diálogos será realizada na medida do possível, uma vez que uma das características peculiares de Avenida Brasil é a informalidade dos diálogos, por isso, é muito comum as cenas mostrarem os personagens falando todos ao mesmo tempo. Desse modo, quando não for possível transcrever tudo, serão transcritas as falas principais e a situação será descrita.
} 
- Significação identificacional: de acordo com os levantamentos na análise acional, os ethé discursivos serão delineados, de forma a entender quais são as vozes por trás da cena.

- Significação representacional: definir quais são os discursos principais, mediante os ethé discursivos. Como esses discursos se relacionam com a prática social, as ideologias por trás da noção de "nova classe C".

A seleção dos capítulos para análise foi realizada em termos qualitativos. Foram selecionadas cenas consideradas importantes para este trabalho, no sentido de trazerem aspectos relevantes para a análise no que diz repeito à representação dos costumes do que seria a "nova classe C". As cenas foram reassistidas nos sites oficiais das tramas ${ }^{11}$, que disponibilizam todos os capítulos.

É pertinente expressar a dificuldade em escolher apenas algumas partes das tramas, pois todos os episódios se mostram relevantes para serem analisados. Assim, em Avenida Brasil, foram privilegiados momentos em que a família de Tufão, a principal da trama, estivesse reunida, possibilitando a observação da interação entre os personagens e seus hábitos enquanto pessoas que ascenderam financeiramente.

As cenas em que a família se reunia na sala de jantar da mansão para fazer as refeições se mostraram interessantes, bem como os momentos em que os personagens têm contato com elementos da cultura legítima e falam de seus usos e consumos.

Outro momento da narrativa que se mostrou conveniente de análise foi a viagem da família a Cabo Frio exibida no mês de julho. Nessa viagem, apesar de Carminha e Max não estarem presentes, foi possível vislumbrar os costumes dos personagens em momentos de lazer. A viagem durou nove capítulos, mas escolhemos apenas uma cena de um deles, de modo a ter a chance de selecionar outras cenas que trouxessem a família reunida na sala de jantar da mansão, com a presença de Carminha e Max, e algum momento de referência a um produto considerado da cultura legítima que novamente manifestam aspectos dos usos e consumos.

Na cena escolhida da sala de jantar, Jorginho, filho de Tufão e Carminha, não está presente, nem a personagem Ivana (irmã de Tufão), pois se trata do dia em que ela conhece Nina. A mesma cena mostra esse encontro no início, mas decidimos cortá-la

\footnotetext{
11 Página oficial da telenovela Avenida Brasil: <http:/gshow.globo.com/novelas/avenidabrasil/index.html>; página oficial da telenovela Cheias de Charme: <http://gshow.globo.com/novelas/cheias-de-charme/index.html>.
} 
(pois o encontro de ambas não se mostrou relevante à nossa proposta de observar os costumes e comportamentos dos integrantes da família) e concentrar a análise na sala de jantar. Nesse trecho, Carminha e Max se expõem bastante, por isso a ideia de analisá-lo, uma vez que ambos não estão presentes nos outros momentos escolhidos.

Ademais, esclarecemos que os usos ${ }^{12}$ e consumos aludidos nos trechos das cenas aparecem na ordem das ritualizações cotidianas, revelando, assim, a conexão da prática discursiva e ritualização na midiatização do consumo e do sentido de classe. É pertinente expor que concebemos o termo ritual conforme as explanações de Trindade e Perez (2013, p. 9) que trazem uma perspectiva transdisciplinar para a definição de ritual de consumo, que manifesta, assim, tanto a dimensão antropológica, quanto a dimensão comunicacional e seus novos horizontes de exploração teórica.

Feitas as considerações necessárias, apresentamos as seguintes cenas escolhidas:

- Capítulo do dia 05 de abril: cena 01 de 20 (de 3 minutos e 48 segundos de duração). Porém, selecionamos o trecho a partir de 01 minuto e 45 segundos. Título dado à cena no site oficial: "Carminha reclama da comida de Janaína".

- Capítulo do dia 23 de julho: cena 03 de 21 (de 2 minutos e 41 segundos). Título dado à cena no site oficial: "Jorginho não se lembra de Cadinho".

- Capítulo do dia 17 de setembro: cena 05 de 25 (de 2 minutos e 56 segundos). Título dado à cena no site oficial: "Muricy reclama de filme indicado por Nina".

De Cheias de Charme, também priorizamos cenas em que as três personagens principais (as empreguetes) estivessem juntas para observar a relação e as diferenças entre elas. O primeiro capítulo se mostrou pertinente de ser abordado, uma vez que expõe como o "embate" entre patroas e empregadas será tratado durante a trama.

Ao contrário de Avenida Brasil, em que Tufão enriquece nos primeiros capítulos da trama, em Cheias de Charme as personagens ganham fama e dinheiro mais ou menos dois meses após o início da telenovela. Essa ascensão econômica em Cheias de Charme é um marco no desenrolar da narrativa e acarreta transformações nas relações das

\footnotetext{
${ }^{12}$ A palavra uso neste contexto é empregada da forma teorizada por Michel De Certeau (1998) para abordar as apropriações realizadas por consumidores, povos ou culturas sobre determinados produtos, linguagens ou outras culturas, por exemplo, utilizando de maneira não prevista pela parte produtora aquilo que lhe é, em algum grau, imposto. Esses usos estão relacionados aos contextos das apropriações cotidianas de consumo.
} 
empregadas com o restante dos personagens da trama, diferente de Avenida Brasil em que o enriquecimento não aparece como um "divisor de águas" na narrativa. Desse modo, julgamos pertinente selecionar mais duas cenas transmitidas após o enriquecimento das empregadas.

A cena em que Maria da Penha retorna da turnê musical do trio e encontra sua casa reformada revelou-se significante para a análise. Também escolhemos a cena em que as três personagens fazem compras em uma loja luxuosa da ex-patroa de Maria Aparecida, pois há a demonstração de uma inversão de papéis, ao passo que a ex-patroa falida serve as ex-empregadas ricas. Do mesmo modo, os rituais de celebração nos fragmentos escolhidos trazem a conexão entre discurso e midiatização do consumo e sentido de classe social.

Dessa forma, as cenas escolhidas são as seguintes:

- Capítulo do dia 16 de abril: cena 24 de 27 (de 2 minutos e 42 segundos). Título dado à cena no site oficial: "As Marias fazem um pacto".

- Capítulo do dia 14 de julho: cena 08 de 29 (de 4 minutos e 11 segundos). Título dado à cena no site oficial: "Penha vibra com a casa reformada".

- Capítulo do dia 23 de julho: cena 01 de 20 (de 4 minutos e 02 segundos). Título dado à cena no site oficial: "Sônia e Máslova ficam horrorizadas com as ironias de Penha".

Dessa forma, a análise discursiva aqui proposta pretende - considerando os devidos limites deste trabalho - levantar as nuanças da midiatização do consumo e do sentido de classe social nas cenas escolhidas de Avenida Brasil e Cheias de Charme, na tentativa de averiguar quais aspectos seriam puramente midiáticos, o que dialoga com a realidade social discutida pelos teóricos, quais elementos corroboram com a visão econômica hegemônica, e se há indícios que apontam para mudanças: tanto em relação à visão hegemônica das práticas sociais, como na forma de representar as classes dentro do gênero telenovela. 


\section{AVENIDA BRASIL E CHEIAS DE CHARME, AS NUANÇAS DA MIDIATIZAÇÃO DO CONSUMO E DO SENTIDO DE CLASSE}

Neste capítulo, analisaremos o discurso das cenas selecionadas de Avenida Brasil e Cheias de Charme, de acordo com o protocolo de análise explicitado no capítulo anterior. O objetivo é averiguar como se dá a midiatização do consumo e do sentido de classe social na representação do que vem sendo chamada pela mídia de "nova classe C" e é concebida neste trabalho como uma nova classe trabalhadora, ou batalhadores (SOUZA, 2012).

Conforme explicado anteriormente, a análise será realizada de forma dialógica e interdiscursiva com a prática discursiva e a prática social. Esta última, local das ideologias e hegemonias, é contemplada aqui a partir das teorias sociológicas comentadas no primeiro capítulo. Pertence à prática discursiva a enunciação, as condições de produção dos enunciados em questão. Consideramos como parte dessa prática o que foi abordado pela mídia sobre a "nova classe C" e sua representação na telenovela, assunto ilustrado de forma breve no primeiro capítulo, e também a narrativa das telenovelas. É pertinente pontuar que a identificação entre a "nova classe C" e as duas tramas foi realizada pela própria mídia por meio de matérias jornalísticas, por exemplo.

Assim, primeiramente, faremos a contextualização narrativa com os principais acontecimentos e personagens das tramas, para, em seguida, descrever e transcrever as cenas escolhidas. A partir disso, a análise propriamente dita terá início, levando-se em consideração a significação representacional, identificacional e acional do discurso, do modo já explanado.

\subsection{CONTEXTO NARRATIVO DE AVENIDA BRASIL}

A telenovela Avenida Brasil, de João Emanuel Carneiro, foi transmitida do dia 26 de março de 2012 a 19 de outubro do mesmo ano (no sábado dia 20 de outubro houve a reprise do último capítulo), na Rede Globo às 21 horas. A trama, que se passa no Rio de 
Janeiro, totalizou 179 capítulos e contou com 45 personagens, de acordo com o site oficial do produto. ${ }^{13}$

Conforme exposto anteriormente, a maioria dos personagens é do núcleo pobre localizado no bairro ficcional Divino, em Madureira, zona norte do Rio de Janeiro, onde se encontra a mansão da família do personagem Tufão (Murilo Benício), que enriqueceu como jogador de futebol e se manteve no mesmo bairro.

A narrativa principal trata da vingança de Nina (Débora Falabella) contra Carminha (Adriana Esteves). Nina, quando criança, chamava-se Rita (Mel Maia) e morava com o seu pai Genésio (Tony Ramos) e a madrasta Carminha, que a maltrata frequentemente e planeja um golpe contra o marido com a ajuda de seu amante Max (Marcello Novaes).

Genésio descobre o plano com a ajuda da filha, escapa do golpe, enfrenta a esposa e acaba ferido. Desorientado, andando pela Avenida Brasil no intuito de denunciar a mulher, Genésio é atropelado por Tufão, que acaba de vencer um campeonato de futebol no Divino Futebol Clube. Ao ser acudido pelo jogador, o homem tenta explicar o ocorrido, mas só consegue pronunciar o nome da esposa antes de morrer. Tufão, ao ouviu o nome da mulher, entende erroneamente que deve protegê-la.

Com a morte de Genésio, Carminha e Max abandonam Rita em um lixão, local onde ambos cresceram. Tufão se aproxima de Carminha, que se aproveita do sentimento de culpa do jogador, o seduz e se casa com ele por interesse. Ela engana toda a família de Tufão, pois continua o romance com Max às escondidas. Rita, por sua vez, é adotada por uma família da Argentina, que lhe dá o nome de Nina. Depois de adulta, ela retorna ao Brasil para se vingar de Carminha. Como era chefe de cozinha na Argentina, a moça se infiltra como cozinheira na casa de Tufão, por meio de uma amizade virtual com a irmã do craque, Ivana (Letícia Isnard).

Essa história de vingança se estende até o final da trama. Nina ganha a confiança dos integrantes da família e até mesmo de Carminha; porém, ela descobre nos primeiros capítulos, que a vilã de quem pretende se vingar é a mãe de seu namorado de infância do lixão, o Batata (Bernardo Simões). O garoto é adotado por Tufão e Carminha, que omite do marido o fato do menino ser seu filho real com Max. Com a adoção, Batata é renomeado Jorginho, como o nome real de Tufão, e quando adulto é interpretado por Cauã Reymond.

$13<$ http://gshow.globo.com/novelas/avenida-brasil/index.html>. 
A família principal é formada por Tufão, sua esposa Carminha, sua irmã Ivana, a filha do casal Ágata (Ana Karolina), que não é filha verdadeira de Tufão, Jorginho, os pais do jogador Leleco (Marcos Caruso) e Muricy (Eliane Giardini) e Max, que casa-se com Ivana apresentado por Carminha. Com a separação de Muricy e Leleco, mais dois personagens entram para a família, são eles: Adauto (Juliano Cazarré), namorado de Muricy, e Tessália (Débora Nascimento), namorada de Leleco. Este último muda-se de casa com a separação, mas está sempre presente.

Na mansão construída no Divino, Carminha leva uma vida de madame, desvia dinheiro do marido e se encontra escondido com o cunhado Max, que não possui um trabalho fixo e vive à custa do dinheiro da família. A vilã finge ser uma mulher tradicional, moralista e devota perante os familiares. Ela simula ser uma vigilante da moral e dos bons costumes, diz fazer caridade e frequentar a igreja.

O resto da família, por sua vez, mantém o estilo de vida simples. Leleco, por exemplo, demonstra simplicidade no modo de vestir, ele sempre utiliza bermuda, camiseta regata, chinelo, corrente no pescoço e, com frequência, óculos escuros na cabeça. Essa simplicidade da família faz com que Max questione em uma conversa com Carminha o porquê de Tufão precisar ter tanto dinheiro se o programa preferido dele é comer "churrasquinho de gato" em frente ao bar do Silas (Ailton Graça).

Max ainda expõe que Ivana reaproveita presente e o repreende quando joga no lixo sabonete velho, que para ela deve ser usado até o "toquinho". Ivana se demonstra bastante controlada com o dinheiro, conforme exposto, e habilidosa com os números. É ela quem cuida da administração do salão de beleza que Tufão abriu em sociedade com Monalisa (Heloísa Périssé).

Ao contrário dos costumes simples, a mansão da família ostenta riqueza com exagero, demonstrando o gosto de Carminha. Leleco, inclusive, se incomoda e critica a casa em dada conversa com Monalisa, alegando que Carminha "pirou", comprou e gastou muito dinheiro, enchendo o imóvel de empregados, de "coisas". Para ele, a residência tornou-se parecida a um museu, "tudo coisa metida...fresca".

A decoração da mansão é uma mistura de estilos e apresenta, por exemplo, papel de parede que combina com a estampa do sofá branco e preto, o qual abriga almofadas com outra estampa; vários detalhes dourados, como o corrimão da escada, moldura do espelho e frisos das portas; muitos objetos de decoração, como grandes vasos, estatuetas, porta-retratos, gato de porcelana e abacaxis decorativos. A cozinha também 
chama a atenção com utensílios coloridos, como as panelas vermelhas. Por fora, a mansão é imponente e destoa do restante do bairro.

Os personagens do núcleo rico da telenovela zombam da mansão. Débora (Nathalia Dill) - namorada de Jorginho, e filha de Cadinho (Alexandre Borges), do qual Muricy fora empregada - afirma que a residência do namorado é hilária, sem descrição. Na festa de bodas de Carminha e Tufão, Verônica (Débora Bloch), mãe de Débora, conhece o local do lado de fora, muito mais enfeitado que o habitual, e declara ser pior do que pensava "é o circo dos horrores". Cadinho em resposta à esposa diz estar adorando, para ele "a classe operária vai ao paraíso".

Os integrantes da família de Tufão aparentam ignorância em determinados assuntos e problemas de português, como é o caso de Muricy. Percebe-se, no desenrolar dos capítulos, que a pequena Ágata tem condições melhores de educação, faz viagem ao exterior, aprende francês, por exemplo, e demonstra ter mais conhecimento que seus parentes. Ironicamente, Nina, que trabalha como cozinheira, é uma moça culta, oferece dicas de livros e filmes para a família. A partir de seus conselhos, Tufão começa a ler mais e é frequentemente gravado lendo livros de autores consagrados como Kafka, Flaubert, Machado de Assis, Eça de Queiroz, entre outros. A moça também traz conhecimento gastronômico para a família, ao apresentar pratos refinados e pertencentes a outras culturas.

É pertinente destacar que, como aponta Ronsini (2012), o gênero melodramático não questiona as assimetrias sociais, mas as afirma em tom humanizado, compactuando com a injustiça social ao reproduzir que ser pobre é bom e que o povo é mais feliz que a elite. Essa reprodução fica evidente em Avenida Brasil quando Monalisa tenta morar em bairro nobre do Rio de Janeiro, mas não se sente à vontade e prefere voltar para o subúrbio. Além disso, Cadinho, que pertence ao núcleo rico da trama, muda-se para o bairro Divino quando perde o seu dinheiro. Inclusive, suas mulheres Verônica, Noêmia (Camila Morgado) e Alexia (Carolina Ferraz), no último capítulo, se casam com ele no Divino Futebol Clube. Na cerimônia, Cadinho faz um pronunciamento, dizendo que nasceu duas vezes, a segunda vez foi quando se mudou para o Divino, onde encontrou a felicidade.

Ademais, conforme expusemos no primeiro capítulo, temos em Avenida Brasil, em um primeiro olhar, a presença do esforço individual e da meritocracia na ascensão financeira e no consumo dos personagens, nos termos expostos por Ronsini (2012). Já o 
fato de Tufão permanecer no mesmo bairro dialoga com a característica comunitária da nova classe trabalhadora (SOUZA, 2012, p. 49), bem como o hábito cultural pertencente à classe de origem.

Isto posto, temos os aspectos gerais da enunciação, da prática discursiva, que estará presente nos enunciados que serão analisados. Partiremos, assim, para a descrição e a análise das três cenas explicitadas no capítulo anterior: "Carminha reclama da comida de Janaína", "Jorginho não se lembra de Cadinho" e "Muricy reclama de filme indicado por Nina".

Conforme exposto no protocolo de análise, às vezes não foi possível entender perfeitamente o que os personagens falavam. A maioria das conversas é bastante informal, as falas costumam ser rápidas e, muitas vezes, mais de um personagem toma a palavra ao mesmo tempo. Desse modo, as conversas paralelas e as falas proferidas ao mesmo tempo nem sempre estão presentes na transcrição aqui realizada.

Além disso, a própria informalidade das cenas dificulta captar as palavras exatamente como foram proferidas, principalmente no caso do personagem Tufão, que tem um tom de voz mais baixo, costuma repetir as palavras e às vezes não profere uma oração linear, com começo, meio e fim marcados. Características essas que são típicas da linguagem falada, por isso a dificuldade de passá-la para a escrita. Assim, as palavras foram transcritas coforme o entendimento possível.

É importante explicar que estão em itálico os termos de origem estrangeira, alguns nomes próprios, expressões que não formaram uma palavra com sentido, palavras pronunciadas incorretamente ou que não existem (no dicionário e também não são abreviações ou formas coloquiais de outros termos), termos muito coloquiais, palavras repetidas uma seguida da outra, problemas de concordância, ou palavras pronunciadas com ênfase de modo a dobrar uma letra, por exemplo. Algumas expressões coloquiais usadas no português do dia a dia não foram marcadas em itálico, mas procurou-se transcrevê-las da forma proferida com o intuito de ilustrar o tom informal da cena, como a abreviação "cês" e as expressões "né", "ó" e "tá". 


\subsection{ELEMENTOS DA REPRESENTAÇÃO DISCURSIVA DA NOVA CLASSE} TRABALHADORA EM AVENIDA BRASIL

Da primeira cena selecionada "Carminha reclama da comida de Janaína", analisamos o trecho a partir de 1 minuto e 45 segundos, conforme explicado no protocolo de análise, que se passa na sala de jantar da mansão, onde almoçam Carminha, Tufão, Muricy, Leleco, Max e Ágata. Também está presente Janaína, a faxineira da casa que "quebra um galho" na cozinha. A empregada encontra-se em pé, com seu uniforme vermelho, próxima à mesa de refeição, enquanto os patrões se alimentam. Na mesa, há copos com suco e cerveja, além da comida, os abacaxis decorativos, uma pequena estátua de mico que serve de suporte para fruteira, entre outros objetos. Trata-se de um ritual de alimentação, de uso refeição, no sentido de representar um contexto cotidiano de uso na prática de consumo.

Há um samba de fundo tocando baixo, sem letra, que acompanhava o final do trecho anterior. O som só está presente nos primeiros segundos do fragmento, que tem início com Muricy e Leleco discutindo.

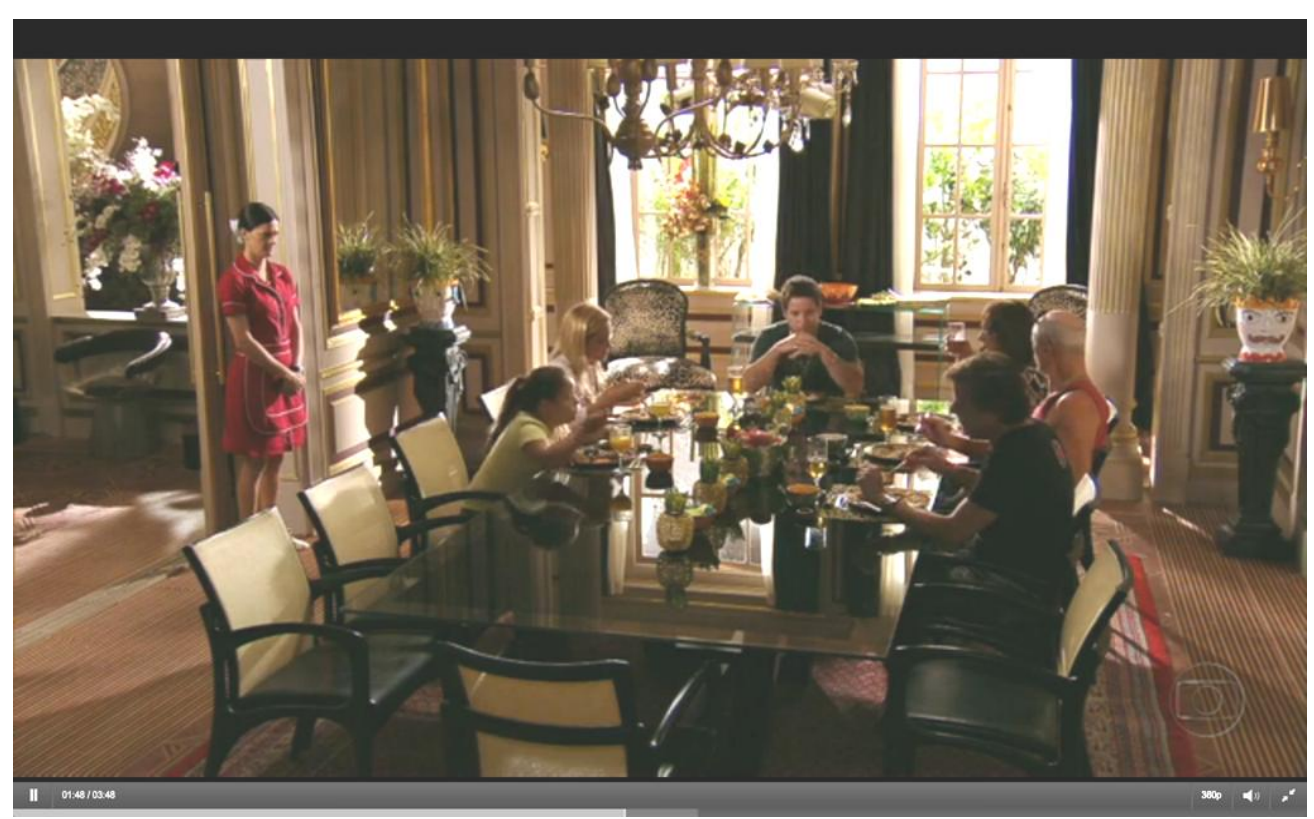

Figura 1 - Imagem do início do trecho analisado, família reunida na sala de jantar da mansão

Fonte: <http://gshow.globo.com/novelas/avenida-brasil/capitulo/2012/4/5/ivana-apresentacarminha- a-nina.html> 
Leleco, que usa uma regata vermelha, corrente no pescoço e óculos na testa: "Não tá me ouvindo, Muricy? Isso aqui tá seco, não dá pra comer, bota mais feijão pra mim?". - Ele remexe a comida com o garfo.

Muricy dirige-se a Tufão: "Meu filho, você tá ouvindo um zumbido?".

Tufão, que também usa corrente no pescoço: "Hum.”.

Muricy fala com os olhos fechados para enfatizar o que diz, enquanto segura o copo de cerveja no ar: "Um ruído chaato. Ah, que bom parou.".

Leleco: "Parou. Muricy...".

Muricy grita: “Ai, meu Deus, voltou!”.

Leleco exclama: "Meu Deus, digo eu! Será possível? Eu já falei pra você que eu não tenho nada com a Tessália. Nunca tive. Ó, eu fui gentil com a moça. Só isso, caramba. Meu filho, sua mãe, eu vou dizer uma coisa, sua mãe, ela posa de santinha, olha a cara dela...".

Muricy: "Eu sou santinha.".

Leleco ri e zomba da esposa.

Muricy fala ao mesmo tempo em que Leleco ri: “... tá pensando o que?”.

Leleco: “É, muito. Aí ela não percebe que eu vejo ela de olho lá nos garotões do charme, do charme...".

Muricy apanha um guardanapo e começa a bater em Leleco com o objeto e grita: "Que, que de olho nos garotão do charme. É tudo mentira isso que seu pai tá falando. Isso é calúnia sua.”.

Tufão, que usa uma corrente no pescoço também, segura o copo de cerveja: "Me inclua fora dessa".

Carminha, que veste camisa branca, o que lhe é de costume: "Tua mãe tem razão tá. Essa Tessália aí também tá no meu radar.”.

Muricy, sem ser enquadrada na câmera: "Obrigada, querida.”.

Carminha: "Aliás, quero saber direitinho como é que vai ser essa tal foto aí do outdoor.". - enquanto ela fala a câmera capta atrás de Carminha um grande vaso de plantas, apoiado em um móvel, com um rosto pintado.

Muricy fala olhando para Leleco: “Ah, nossa, isso eu também queria saber.”.

Tufão bate na mesa como quem vai fazer um anúncio: "Deixa eu explicar. A gente vai fazer o seguinte. A gente vai associar o futebol com os nossos salões de cabeleireiro, entendeu? Então, o que a gente vai fazer? A gente vai, todo mundo sabe 
que eu sou sócio da parada, então a gente vai botar uma menina chapinha fazendo embaixadinha.".

Max: “É isso.".

As pessoas falam ao mesmo tempo.

Carminha: "Cês não me aprontem nada indecente, pelo amor de Deus. Porque se deixar seguir pela cabeça daquela sócia de vocês lá, aquela mulherzinha amoral, nós vamos acabar em Sodoma e Gomorra.”.

Leleco: "Que é isso?”.

Tufão: "Sodoma e gangorra?". Risos.

Ágata balança o rosto.

Marx: “Ô Carmen Lúcia, a popaganda ela pede um pouco de sensualidade.”.

Carminha se exalta: "Tô vendo que é indecente.".

Muricy: "Tô vendo tudo.".

Tufão fala rindo: "Fala logo Max. Fala logo, que a mulher tá de calci... de u... de biquíni lá...".

Carminha: "Foi ideia tua, né, Max.".

Risos de fundo. Leleco bate palmas.

Max toma a palavra como quem entende muito de propaganda, ele usa camiseta com desenho e corrente no pescoço: "Foi ideia minha. Não, cês têm que entender que isso isso é uma questão de pesquisa, entendeu, é pré storm...".

Carminha: "Bad o que?".

Tufão ri.

Max: "Pré storm".

Carminha: "Olha aqui, com que cara eu fico quando eu encontrar o padre Solano?”.

Leleco murmura sem estar enquadrado na câmera: "Ah bom.”.

Carminha: "Como é que eu vou explicar pra ele o anúncio da minha firma. Uma mulher pelada fazendo embaixadinha. Problema meu né, problema meu, deixa que eu resolvo, é isso...".

Muricy fala sem ser enquadrada na câmera: "Problema nosso, depois a gente tem que se resolver...".

Carminha dá um tapa em Tufão: "Se tu relar...” - Tufão ri - “... um dedo naquele fio de cabelo mal alisado, você tá perdido na minha mão, Tufão. Perdido.”. 
Carminha: "Janaína.".

Janaína se aproxima: “Aqui.”.

Carminha fala se referindo ao prato: "Que é isso, minha filha, tá fazendo racionamento de grão? Ou é sopa de feijão?”.

Foco no rosto de Janaína. Toca um som curto de cuíca.

Neste instante, analisaremos a significação acional, identificacional e representacional do enunciado exposto. Na significação acional, temos o texto como modo de (inter) relação em eventos sociais (RESENDE; RAMALHO, 2005). Esse significado tem a ver com a forma como as relações sociais entre os participantes do discurso são representadas e negociadas (FAIRCLOUGH, 2001) e está atrelado aos elementos do gênero discursivo, como fora explanado em capítulo interior, enquanto convenção e possibilidade de inovação.

Conforme a explicação realizada, consideramos a telenovela como um gênero secundário (complexo), composto por gêneros primários (simples) - como réplicas ou simulações de diálogos do gênero primário -, segundo as teorias do filósofo russo Bakhtin (2003). Entende-se a telenovela, dadas as devidas diferenças, do modo em que Bakhtin (2010) considerava a prosa romanesca, constituída na corrente de forças descentralizadoras e composta por pluralidades. Porém, os gêneros primários como parte dos gêneros complexos, na verdade, são recontextualizados em uma obra e perdem, assim, o contato direto com a realidade concreta.

Esses gêneros primários, que integram os complexos, aí se transformam e adquirem um caráter especial: perdem o vínculo imediato com a realidade concreta e os enunciados reais alheios: por exemplo, a réplica do diálogo cotidiano ou da carta no romance, ao manterem a sua forma e o significado cotidiano apenas no plano do conteúdo romanesco, integram a realidade concreta apenas através do conjunto do romance (BAKHTIN, 2003, p. 263-264).

No trecho destacado de Avenida Brasil, temos a simulação de um gênero primário dentro da teledramaturgia, de conversa informal familiar, o que é comum no gênero telenovela, que simula situações cotidianas vividas em família. O movimento da câmera é como o olho do telespectador que assiste à cena. Ela muda constantemente para focalizar os personagens enquanto falam. Espera-se, como é feito, que as atores interpretem seus personagens com naturalidade, sem olhar para a objetiva, por exemplo.

A comida e o copo de cerveja que parecem reais, o cenário da sala de jantar, bem como a duração da encenação (de 2 minutos e três segundos) fazem parte do que 
Maingueneau (2004) denomina contrato do gênero discursivo, ou seja, as normas de determinado gênero que são esperadas e aceitas. Do mesmo modo, a interpretação da conversa informal preenche a expectativa do que seria um momento familiar de refeição na telenovela. Temos, assim, a representação de um ritual de consumo alimentar, o almoço à mesa.

Pois bem, esmiuçaremos, então, a linguagem e as relações entre os personagens peculiares a este gênero primário específico da telenovela Avenida Brasil. Num primeiro momento, já é perceptível que se trata de um relacionamento entre pessoas simples, o que destoa da pomposa sala de jantar e da formalidade de Janaina, a postos para qualquer necessidade dos patrões.

Alguns objetos de decoração também chamam a atenção por serem exóticos, como é o caso das miniaturas de abacaxi, da estátua de mico que sustenta a fruteira e o vaso com um rosto pintado.

A briga entre Leleco e Muricy demonstra a exposição da intimidade do casal à mesa, diante dos familiares, inclusive da pequena Ágata e da empregada doméstica. $\mathrm{O}$ tom é de comédia. Muricy é dramática, bate no marido com o guardanapo, finge não ouvir Leleco, que, por sua vez, zomba da esposa, enquanto Tufão observa com ar de riso. A postura dos personagens é informal e as falas e expressões bastante corriqueiras, como “... bota mais feijão pra mim?”, "caramba” e "meu Deus do céu”.

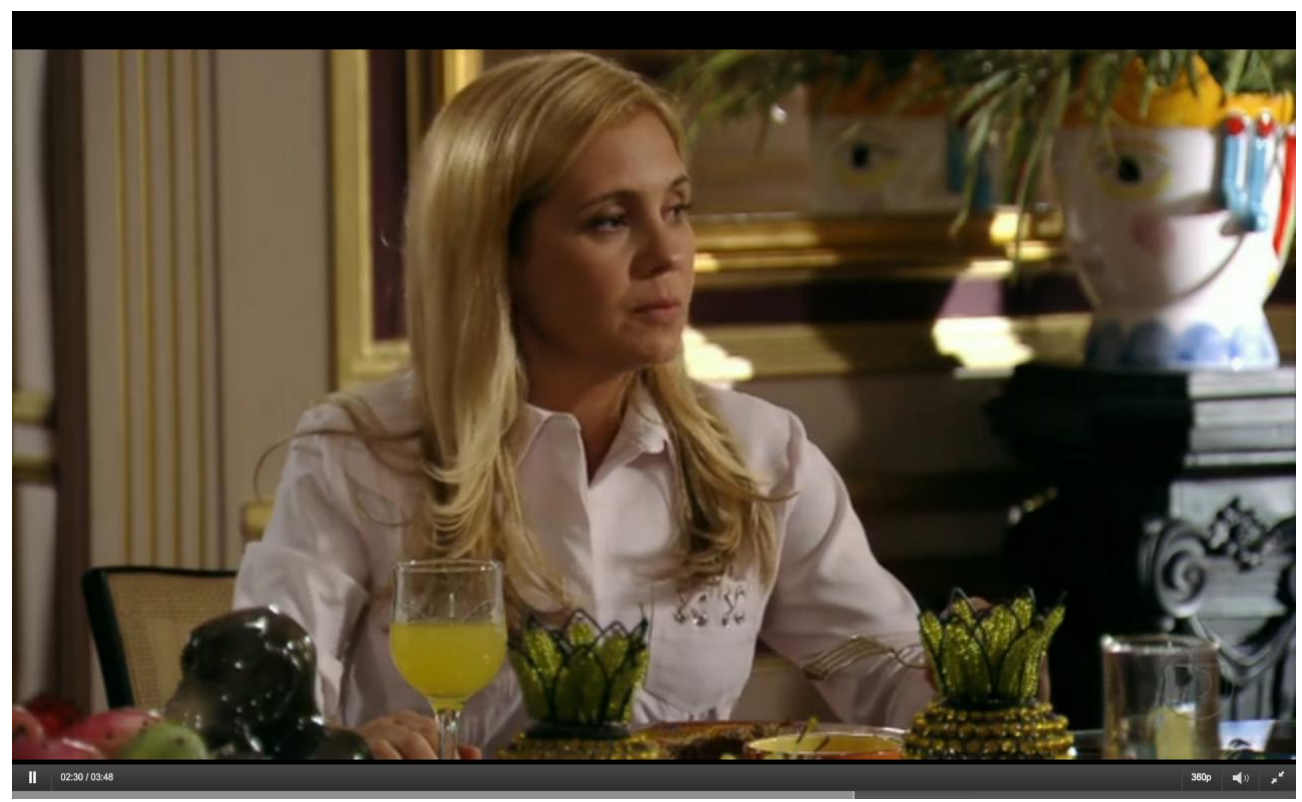

Figura 2 - Imagem da personagem Carminha. Na mesa e atrás da personagem é possível visualizar os objetos decorativos da casa

Fonte: <http://gshow.globo.com/novelas/avenida-brasil/capitulo/2012/4/5/ivana-apresentacarminha-a-nina.html $>$ 
Leleco e Muricy, principalmente, não demonstram cerimônias à mesa. O modo do pai de Tufão mexer a comida com o garfo e sua disposição corporal são relaxados. Similarmente, Muricy não apresenta compostura em seus gestos, quando finge não ouvir Leleco ou ao bater no marido com o guardanapo. Carminha também tem seus momentos de exaltação ao dar um tapa no marido e demonstrar ciúmes: "Se tu relar ... um dedo naquele fio de cabelo mal alisado" em referência à personagem Tessália.

Quando Leleco fala charme, ele se refere ao baile charme. Trata-se de um baile nascido debaixo de um viaduto do bairro Madureira no Rio de Janeiro, embalado com um estilo de Black Music ${ }^{14}$, que é representado na telenovela e frequentado pelos moradores do Divino. Em resposta à insinuação de seu marido, Muricy levanta a voz, o que lhe é frequente, e também comete erros de concordância, "os garotão".

Tufão quando pede "me inclua fora dessa" faz uma brincadeira com a semântica do verbo "incluir" que não pode ser combinado com a palavra "fora". Mas, a impressão é que o personagem tem o intuito de brincar e não comete o erro sem pensar, já que essa expressão é conhecida popularmente.

A discussão entre Leleco e Muricy tem como motivo o ciúme que Muricy possui da personagem Tessália, eleita a "Garota Chapinha", ou seja, a garota propaganda da rede de cabeleireiros de Tufão e Monalisa. Ouvindo a discussão, Carminha apoia a sogra, ela utiliza a expressão "está no meu radar" para indicar que está atenta a Tessália. Tufão também usa a palavra "parada" de forma coloquial, para designar o seu negócio. Quando ele diz "a gente" para explicar a propaganda, fica implícito o referimento às pessoas envolvidas nessa publicidade, o que inclui ele e Max.

Carminha, então, profere um discurso moralista, se referindo à sócia do marido Monalisa (que já fora namorada do Tufão) como mulher amoral. Ela aborda o negócio do marido como "minha firma", mas quanto à sócia, da qual ela quer distância, ela coloca como "sócia de vocês".

Carminha também faz referência ao personagem padre Solano e à Bíblia, citando "Sodoma e Gomorra", duas cidades que teriam sido destruídas por Deus com enxofre e fogo devido a atos imorais. Quando a personagem faz a citação dessa passagem bíblica, torna-se evidente que Leleco e Tufão desconhecem o tema. Inclusive, o jogador brinca e substitui "Gomorra" por "gangorra". Muricy concorda com o moralismo da nora e

\footnotetext{
${ }^{14}$ Informações disponíveis em: <http://globotv.globo.com/rede-globo/globo-reporter/v/conheca-o-bailecharme-que-inspirou-o-autor-de-avenida-brasil/2199397/>. Acesso em: abr. de 2014.
} 
quando afirma "problema nosso..." ela quer dizer dela e da Carminha, as duas mulheres adultas da mesa.

O modo de Carminha se vestir também condiz com a imagem tradicional pretendida por ela, pois a camisa branca utilizada nessa cena faz parte de um estilo que a acompanha durante toda a trama na presença da família. Além disso, ela não acompanha os adultos com a cerveja. Ela bebe suco, contribuindo com a postura almejada de pessoa correta.

Os homens brincam e riem quando anunciam como será a propaganda do outdoor. Nesse instante, Marx diz "cês têm que entender" para Muricy e Carminha, as duas que demonstram não gostar da ideia. Com ares de quem entende do assunto, Max tenta falar brainstorming 15 , mas pronuncia "pré storm", demonstrando ignorância no assunto. O personagem também pronuncia a palavra "propaganda" erroneamente.

É importante destacar as roupas informais dos homens, principalmente Leleco, que está, na maioria das ocasiões, com camiseta regata. Além disso, há as falas altas e ao mesmo tempo, que demonstram informalidade e intimidade. Também é perceptível o viés cômico, presente nos exageros da briga entre Leleco e Muricy, as brincadeiras de Tufão, as falas erradas de Max e o cinismo de Carminha. Há o uso coloquial da língua, de modo geral, e erros de português, o que sugere simplicidade e o baixo capital cultural de origem da família.

No final da cena, Carminha chama Janaina para reclamar da comida, e um som de cuíca toca para marcar o clima da situação. Embora seja difícil expressar em palavras a sensação provocada pelo som, é possível entendê-lo como parte da encenação, ele está tão encaixado na proposta dessa última fala e no close no rosto de Janaina, que não causa qualquer estranhamento. É plausível afirmar que os sons e músicas fazem parte do gênero telenovela. Mesmo nos momentos de informalidade e situações cotidianas, eles são incorporados com naturalidade para marcar a relação e o estado de ânimo entre os personagens. No caso da cuíca, trata-se de um instrumento popular, utilizado nos arranjos musicais do samba.

Desse modo, a partir do levantamento da significação acional, é possível seguir para a significação identificacional, que está relacionada ao modo como as identidades são estabelecidas no discurso (FAIRCLOUGH, 2001). Como explicamos no capítulo

\footnotetext{
15 Brainstorming quer dizer, literalmente, tempestade de ideias. O termo é utilizado para designar um método da publicidade que explora a capacidade criativa das pessoas, que se reúnem com o objetivo de terem ideias, ou trazerem uma solução, para uma propaganda, por exemplo.
} 
anterior, o significado identificacional, relaciona-se ao ethos, que é entendido como o orador, cuja postura extrapola o texto em si, o fiador, cuja voz não está explícita no enunciado (MAINGUENEAU, 2004).

O ethos nos é possível pelos indícios textuais da significação acional que dialogam com a enunciação. É importante lembrar que, conforme expõe Maingueneau (2008), o ethos é uma noção discursiva e não se refere à imagem do locutor fora de situação de fala. Ele se manifesta pelo caráter e pela corporalidade, ou seja, pela dimensão vocal e o conjunto de determinações físicas e psíquicas (MAINGUENEAU, 2004).

O ethos pode ser entendido também como um tom que dá autoridade ao que é dito, que permite ao enunciatário construir uma representação do corpo do enunciador (não o corpo efetivo). $\mathrm{O}$ universo de sentido de um discurso se impõe, segundo Maingueneau (2004), pelo ethos e pelas ideias transmitidas, que se apresentam justamente de acordo com uma maneira de dizer que remete a uma maneira de ser.

Assim, o nosso intuito é entender a maneira como a cena é transmitida, qual é o tom, a voz que está por trás dessa representação, qual é a imagem que o caráter e o corpo da cena querem transmitir para se construir uma maneira de ser dessa família ficcional da nova classe trabalhadora.

Em um primeiro momento, a cena nos sugere um ethos cômico, presente no exagero da briga, nas falas erradas, nas brincadeiras e até mesmo no cinismo de Carminha. É engraçado ver a forma como Max erra "brainstorming", assistir à Muricy brigando com Leleco, o modo que esse último provoca a esposa e as brincadeiras de Tufão. São divertidas, inclusive, as referências de Carminha à igreja e à Bíblia, sobretudo pelo fato de a personagem ser dissimulada e ser ela a amoral da história.

Existe também uma voz popular, que demonstra a relação próxima entre os personagens, o exagero no tom da voz e no drama de Muricy, por exemplo, a falta de cerimônia, a exposição da intimidade e até mesmo a ignorância a respeito de determinados assuntos, bem como a cerveja acompanhando a refeição e o jeito relaxado de Leleco. A citação ao baile charme é outro indicativo desse ethos, pois manifesta que Muricy e Leleco frequentam o local, que é popular e localiza-se no bairro suburbano onde moram. Toda a encenação sinaliza um conjunto de objetos e produtos de consumo que corporificam o ethos dos personagens em seus processos de identificação com padrões de gostos. 


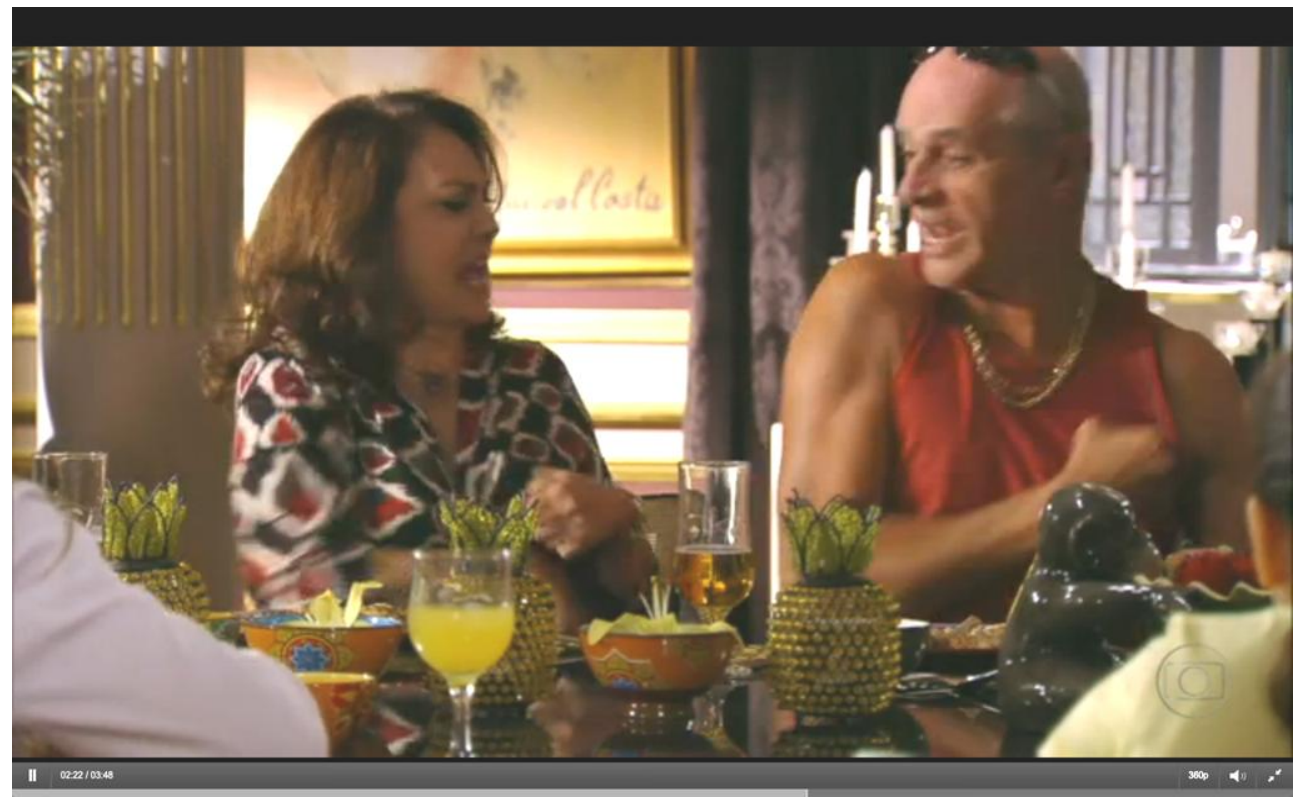

Figura 3 - Muricy e Leleco discutem à mesa

Fonte: <http://gshow.globo.com/novelas/avenida-brasil/capitulo/2012/4/5/ivana-apresentacarminha-a-nina.html>

Há também um tom crítico e irônico no falso moralismo e religiosidade de Carminha, que servem como um reforço à máscara da vilã. Os outros personagens aparentam ignorar as referências religiosas feitas por ela, o que demonstra despreocupação por parte deles em relação a esse assunto. Muricy concorda com Carminha, mas ela demonstra ser uma pessoa ignorante e passional, sua aversão a Tessália está atrelada também ao ciúme.

Outra ironia está no fato de Ágata, a única criança da mesa, ser a mais comportada. Ela não fala nada na cena, o seu rosto só é enquadrado quando Tufão troca “Gomorra” por "gangorra”. Na ocasião, ela balança a cabeça como quem considera a brincadeira tola.

Já o gosto decorativo exótico da vilã, que pretende ser luxuoso, causa certa estranheza e destoa do jeito simples das pessoas da casa. Janaina parada atrás da mesa também representa uma formalidade que não condiz com a postura dos personagens.

Carminha é a única que finge uma compostura diferenciada dos outros, que pretende ser refinada, com a camisa branca fechada e o discurso moralista; porém, ela desliza ao revelar um tom bastante coloquial - por exemplo: "no meu radar", "se tu relar" e ao não entender o que Marx quer dizer com "pré storm" - e, sobretudo, na decoração da casa. Esses dados dialogam com o ethé popular, cômico e também irônico. 
Esses ethé revelam, na significação representacional, um discurso que pretende mostrar as contradições de uma família que enriqueceu repentinamente e continua com o mesmo capital cultural de origem - simples e popular. Essa representação dialoga com a prática social deduzida das teorias do sociólogo Jessé Souza (2012), que aclara o fato da nova classe trabalhadora não ter tido acesso ao capital cultural da classe média. Assim, os batalhadores não têm a ver, em sua visão de mundo prática, com o que se entende por classe média, seus modos e práticas.

A religiosidade e a ostentação da casa estão atreladas à vilã da história e, por isso, não apresentam uma conotação positiva, a priori. Tendem para a comicidade, em determinados momentos, e ironizam a pretensão burguesa, os costumes familiares tradicionais e religiosos.

É pertinente trazer as explicações de Souza (2012) sobre o assunto. O teórico demonstra que o modelo de família burguesa se universalizou com o tempo, condenando outras classes à (sub) humanidade por não disporem dos mesmos pressupostos.

Jessé Souza (2012) expõe que a família nuclear é uma formação recente, desenvolvida na Idade Moderna, com o surgimento da propriedade privada e da família como lugar do sagrado e não do profano, como era anteriormente quando outras organizações sociais se sobrepunham a ela.

A família nuclear, baseada na propriedade privada e no investimento escolar, é, então, uma nova ordem social capaz de reproduzir os privilégios da burguesia.

A universalização de uma condição particular é o princípio fundamental para a legitimação do privilégio e para o estabelecimento da dominação simbólica, sem a qual a dominação econômica se torna instável. E a identificação religiosa entre a família nuclear burguesa e a Sagrada Família, que faz dela emanação do divino, cumpre esta função: torna a estrutura familiar burguesa o princípio normatizador, ou seja, o modelo que guiará toda a sociedade, que guiará mesmo e, principalmente aqueles que não dispõem das condições de existência para vivenciá-la, e só a experimentam pela negação total, pela ausência. (SOUZA, 2012, p. 126).

Desse modo, o discurso burguês e religioso trazido por meio da personagem Carminha, a vilã dissimulada e amoral, é uma ironia. Esse discurso está presente na fala da personagem, na formalidade de Janaina e na decoração da casa, que como foi exposto na contextualização narrativa fora escolhida por Carminha. 
Trata-se de uma brincadeira com a pretensão burguesa que não condiz com o verdadeiro caráter de Carminha e nem com a realidade dos integrantes dessa família, que são espontâneos, não têm cerimônias, falam alto, se vestem de maneira simples, tomam cerveja etc. O discurso popular se demonstra autêntico, em contraposição ao discurso tradicional de Carminha, que é dissimulado.

Além disso, o silêncio de Ágata e sua feição quando Tufão faz a brincadeira podem ser indicativos de que a garota se diferencia de alguma forma do restante da família. Na exposição realizada sobre a narrativa, constatamos que Ágata tem mais oportunidades de educação e demonstra mais conhecimento que os demais, por exemplo.

Desse modo, o sentido de classe social nessa cena é o de uma família da classe trabalhadora que enriqueceu e continua com o mesmo habitus e capital cultural de outrora - o que é transmitido de forma cômica, irônica e popular.

É pertinente destacar que, embora a ficção trate do enriquecimento pelo futebol o que não se enquadra, em um primeiro olhar, à ética do trabalho dos batalhadores transmitida por meio da família, além dos outros elementos narrativos abordados anteriormente que corroboram com a meritocracia - o sentido de classe transmitido dialoga com a realidade da classe trabalhadora das teorias sociológicas de Jessé Souza (2012).

De um modo geral, a cena comentada não contribui com a visão hegemônica meritocrática que naturaliza os "bons modos", a "boa fala" e os "bons comportamentos" como atributos individuais, deslocados da vivência de classe, como expõe Souza quando critica o pensamento dominante de nossa sociedade (SOUZA, 2012).

Ao contrário, o discurso do trecho analisado revela uma família inteira marcada pela posição social de onde veio, o que se repete em outras cenas e se entrelaça aos elementos da simulação do gênero primário dentro dessa telenovela. Pois, a encenação do gênero primário da conversa informal e corriqueira é recorrente em Avenida Brasil e acentuada pela trivialidade das conversas, pelas falas altas e ao mesmo tempo, elementos esses que conotam o estilo popular da família de Tufão.

Partiremos, assim, para a próxima cena: “Jorginho não se lembra de Cadinho", na qual a família (com exceção de Carminha e Max) está na casa de Cabo Frio. O nome da cena reforça o fato de Jorginho ter perdido a memória na trama. É pertinente pontuar que a casa é mencionada nos primeiros capítulos, antes da família morar na mansão. Na 
temporada passada no local, em alguns capítulos do mês de julho, os personagens estranham o fato de Carminha não ter reformado a casa, uma vez que ela havia reservado um dinheiro para isso. O trecho selecionado em questão mostra a família durante um almoço na casa de veraneio.

A cena começa com uma fala de Adauto, enquanto Ágata, sentada no sofá, parece estar fazendo palavras cruzadas. Ao lado da filha, Tufão lê um livro. Ele usa óculos, bermuda, chinelos e uma corrente no pescoço que está sempre com ele. Em cima do sofá há uma manta meio caída. Há algumas cadeiras de praia espalhadas pela casa, que aparenta ser bem simples. No início entra um som de violão bem leve, que logo some.

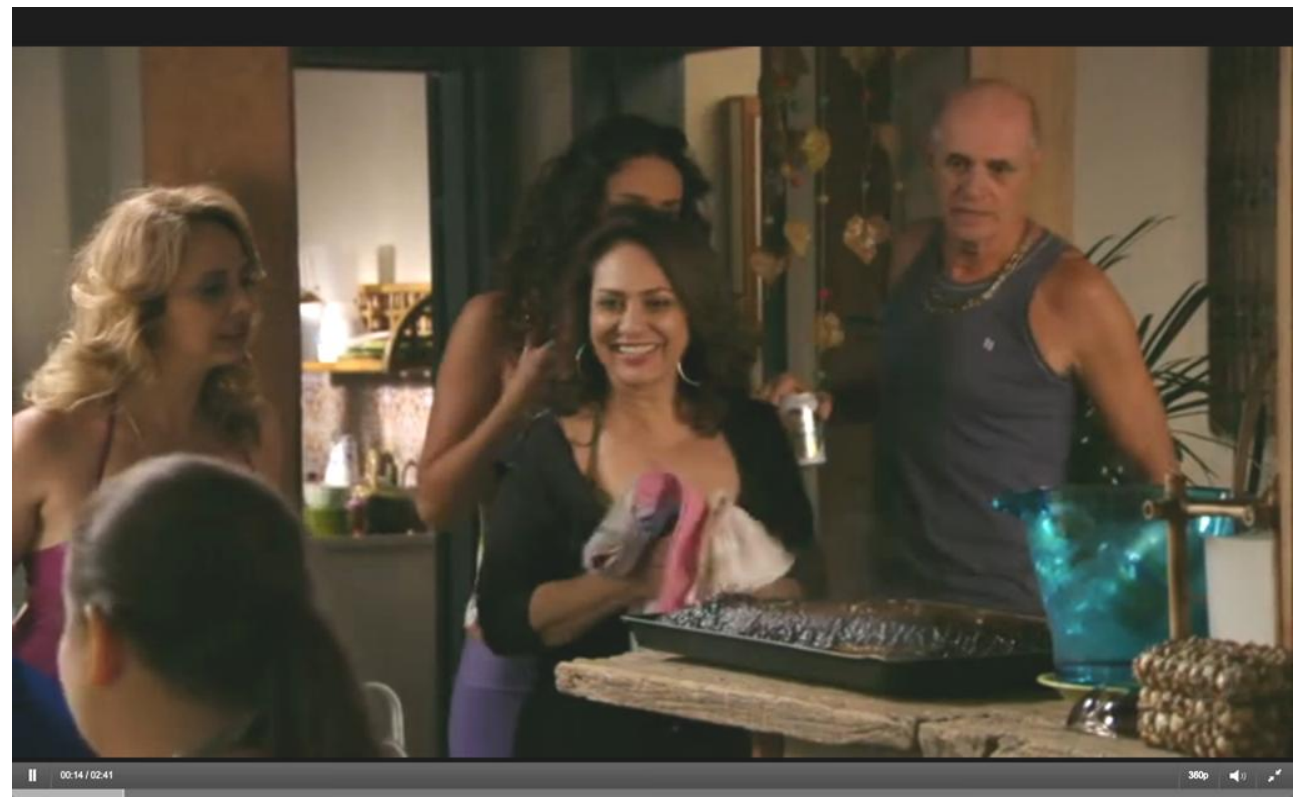

Figura 4 - Na casa de veraneio em Cabo Frio, Muricy traz para a sala o peixe que preparou para o almoço

Fonte: <http://gshow.globo.com/novelas/avenida-brasil/capitulo/2012/7/23/nilo-afirma-quemax-esta-apaixonado-por-nina.html >

Adauto: "Tá bonita a mesa, hein Ivana.".

Ivana: "Não tá? Eu caprichei...".

Ágata se levanta: "Nossa, que cheiro bom, tá me dando uma fome!”.

Ivana: "É, tá cheiroso esse peixe hein."- ela usa um maiô e uma calça.

Muricy murmura da cozinha: "Ai ai ai ai...".

Leleco: "É o peixe, é o peixe, é o peixe! Segura aí." - ele coloca as mãos para o alto e gira em volta do corpo, com uma latinha de cerveja na mão. O personagem usa camisa regata, o que é habitual, corrente no pescoço e chinelos. Adauto, que está próximo a Leleco, também segura uma latinha de cerveja. 
Muricy: "Sai da frenteee! Ai ai ai ai ai."- ela traz a forma com o peixe para a sala, parece estar quente.

Gritos. Conversas altas e ao mesmo tempo. Ivana imita índio.

Muricy, que também parece vestir um maiô por baixo da roupa: "Olha aí. Olha, tá bonito né, não tá?".

Ivana faz cara estranha.

Adauto: "Bem passado né, amor.".

Muricy: "Como a cozinheira não veio né, gente, então eu fiz um peixinho." - Ela se dirige a Ivana - "Vai dando ali (os pratos). O prato do Adauto primeiro.".

Conversas paralelas. Todo mundo está em pé pegando os pratos.

Leleco: "Esse peixe aí ó... esse peixe é afrodescendente? Acho que ele tá meio preto, não tá não...".

Muricy fala com raiva: "Tem ovo na geladeira. A ninfeta sabe fritar?”.

Tessália: "Sei sim, sem sim, cê quer um omelete amor?".

Todo mundo fala ao mesmo tempo.

Tufão: "Cês tão brigando ou é impressão minha, hein?".

Muricy: "Que saco o seu pai também.".

Muricy serve um prato e passa para a Ivana: "Dá esse aqui pro Adauto.".

Leleco zomba de Muricy: "Dá pra Adauto, dá pra Adauto, dá pra Adauto...".

Ivana em pé, servindo os pratos: “Gente, cês lembram? Lembram a última vez que a mamãe foi pra cozinha? Ela foi fazer aquele jantar pros pais da Débora. Lembra, Jorginho?".

Jorginho: “Quando é que foi isso?”.

Tufão, rindo: “... isso aí...fez um bacalhau pro Cadinho lá na década de 80. Não é não? Faz tanto tempo esse negócio!".

Tessália e Leleco riem.

Jorginho: “Quem é Cadinho?”.

Leleco pegando uma batata com o garfo: "Como quem é Cadinho, meu filho? Cadinho teu sogro, ex-sogro, pai da Débora.”.

Tufão faz cara de preocupado.

Muricy entrega um prato para Jorginho: "Toma aqui, meu amor, toma aqui. Juro que dessa vez eu não salguei.”. 
Tessália morde a batata que está no garfo do Leleco, os dois fazem graça um para o outro, demonstrando intimidade de casal.

Adauto para Muricy: “Amor.”.

Muricy senta ao lado de Adauto: “Oi?".

Adauto: "Tá uma delicia.".

Muricy: "Gostou, bebezinho?".

Adauto dá um beijo no rosto de Muricy: "Humm, tá muito bom.”.

Leleco ironiza: “Ai, tá muito bom. Ele gosta de tudo que tu faz né Muricy...”.

Muricy: "Graças a Deus.”.

Leleco: “Igual cachorrinho amestrado não é não?".

Tessália: "Para, Leleco, de implicar com o Adauto, deixa ele.".

Muricy ironiza: “A bonequinha do vovô sabe falar grosso! Gostei dessa vez.”.

Tufão: “Gente, para. Você também para, mãe. Chega, tá bom, chega.".

Ivana: “É, pelo amor de Deus, gente. Que que é isso?".

Murmurinhos.

Ivana fala com o pegador de alimentos na mão: "Olha aqui... aqui, não é porque vocês separaram que tem que viver em pé de guerra. Que que é isso?”.

Todo mundo come, barulho de talheres. Na mesa, além do peixe, há uma travessa de arroz, de salada e de batata.

Tufão: "Exatamente, separaram, mas ainda é família. Vamos ficar tranquilo.".

Leleco, com o garfo na mão, na altura do rosto: “A gente é família, né, Muricy.".

Muricy: "Brigar por que, né?".

Leleco: “Brigar por que né, Muricy?”.

Nesse instante, entra um som curto de cuíca, que marca o clima entre Muricy e Leleco. Parece uma referência ao fato deles terem se encontrado às escondidas em cenas anteriores.

Leleco encara Muricy, enquanto retira uma espinha de peixe da boca.

Adauto: "Aí, Jorginho, parece que comer peixe faz benzão pro célebro, pra memória.".

Muricy e Ivana corrigem Adauto, dizendo que é cérebro.

Ao mesmo tempo, Ágata indaga: "Então cê não come peixe né, Adauto?". 
Ágata: “A Nina me ensinou a fazer um peixe, deixa eu ver se eu me lembro... ah é, você tem que molhar bem no tempero e assar em fogo alto.”.

Tufão: "Qual era aquele aquele aquele peixe que que a Nina gosta de servir pá caramba, como é que é?".

Ivana, com a boca cheia: "Ah, é, vichice... vici... vichisua?".

Muricy: "Não, vichisua é sopa fria.".

Ivana tenta pronunciar novamente, mas é Jorginho quem acerta: “Ceviche.”.

Nesse instante, um samba baixo, sem letra, começa a tocar de fundo.

As pessoas falam ao mesmo tempo, confirmando o que Jorginho disse.

Muricy abraça Jorginho, feliz por ele ter se lembrado.

Leleco: "Lá é ceviche. Aqui, cê vê e fala vixe.".

Leleco, Tessália e Tufão gargalham. Os dois primeiros seguram o garfo com comida no ar.

Leleco: "Desculpa, Muricy.".

Muricy joga um guardanapo no Leleco e acerta o peixe no garfo dele.

Leleco: "Oh, Muricy, tu acertou no peixe, caiu tudo aqui.".

Tufão ri.

Leleco espeta com o garfo o pedaço de peixe que caiu em suas pernas.

Adauto: "Não é obrigado a comer não, viu.".

Jorginho se levanta: "Perdi a fome, dá licença.".

Muricy: "Por quê?".

Ivana: "Gente, não, eu gosto mesmo é dum bom peixinho na brasa, sabe, nada como uma sardinha frita... ai, o Max se esbaldava.".

Leleco: "Num fala no Max hein, minha filha, pelo amor de Deus, vai falar do bundão, agora, na hora da mesa.”.

Tessália cutuca o namorado.

Ivana: "Que que é isso, pai? Que é isso?".

Ágata ri.

Leleco: “Tá bom, então, bundinha vai, bundinha é ...melhorou?”.

Ivana: "Olha aqui, pai. Ele ainda é meu marido, tá. Eu amo, eu amo, tá pai. To com saudade do Max..." - Ela se levanta da mesa e começa a chorar.

O samba de fundo aumenta. 
Muricy abaixa a cabeça rindo. Adauto faz um sinal como de indignação pela situação.

Todo mundo começa a falar ao mesmo tempo.

Adauto: "Não vai embora, come aí.".

Ivana deixa a sala.

Leleco: "Pô, eu diminuí a bunda e...".

Tessália o repreende.

Muricy: "Deixa, daqui a pouco ela volta e come.".

Ágata ri.

Tufão permanece pensativo, com um ar de riso.

Na significação acional dessa cena também temos a simulação de um gênero primário da conversação informal entre familiares na telenovela em uma cena realizada novamente como ritual de alimentação. A conversa é corriqueira e se refere, inicialmente, ao almoço, como a fala "Tá bonita a mesa, hein, Ivana.". Os elementos da cena indicam intimidade e familiaridade entre os personagens, além de um momento de descontração, pois eles estão na casa da praia de Cabo Frio e Ivana e Muricy, por exemplo, usam maiô por baixo da roupa. As outras vestimentas também são informais, principalmente a de Leleco, composta pela mesma regata, bermuda e corrente no pescoço de sempre. Há falas altas e ao mesmo tempo também, como o grito de Muricy quando traz o peixe para sala: "Sai da frenteeee".

Nos primeiros instantes, a cena simula a expectativa do almoço de família, pois há demonstração de fome e empolgação quando Muricy traz o peixe da cozinha. Ivana, inclusive, imita índio, assim como Leleco, que brinca ao levantar as mãos para o alto e anunciar o peixe. Essas são manifestações de intimidade e informalidade no ambiente. Ademais, Leleco segura uma latinha de cerveja na mão, assim como Adauto, reforçando a ideia de descontração e simplicidade.

Há um viés cômico quando os personagens veem o peixe que está um pouco queimado. Leleco provoca a esposa, inclusive, em tom de brincadeira “...esse peixe é afrodescendente?". Muricy se irrita e começa a provocar o ex-marido, implicando com sua namorada Tessália, ela se refere à moça como "ninfeta" e "bonequinha do vovô", devido à grande diferença de idade entre os dois. Leleco também ironiza Adauto ao chamá-lo de "cachorrinho amestrado". 
O clima é de bagunça e também há exposição de intimidade na cena, na medida em que Leleco e Muricy implicam um com o outro na frente de todos, além dos carinhos trocados entre Leleco e Tessália e Muricy e Adauto. O mesmo som de cuíca da primeira cena soa no momento em que Muricy e Leleco se encaram e acatam os conselhos dos filhos "brigar para por que, né?", o som traz comicidade à cena porque remete ao fato de ambos terem se encontrado às escondidas em cenas anteriores. Leleco olha para a ex-esposa no mesmo momento em que tira uma espinha de peixe da boca, o que poderia ser encarado como deselegância se não estivesse no contexto descrito.

Tufão, que mantém o mesmo ar de riso da primeira cena ao observar os exageros da família, usa linguagem coloquial como o restante e erros de concordância como “vamos ficar tranquilo”. A fala coloquial e informal também está presente na cena em outros momentos como quando Muricy exclama "que saco o seu pai também”. A postura à mesa é relaxada, Leleco e Tessália brincam com a batata, por exemplo, as pessoas falam segurando o garfo no ar, Ivana conversa com a boca cheia etc.

O personagem Adauto é visto na família como uma pessoa de inteligência limitada. Inclusive, era analfabeto e a trama mostra o momento em que ele começa a aprender a ler e a escrever. É comum cometer erros de português, como o que ele faz nessa cena com “célebro", também utiliza a palavra "benzão", indicando informalidade. Ágata brinca com Adauto e Ivana e Muricy o corrigem.

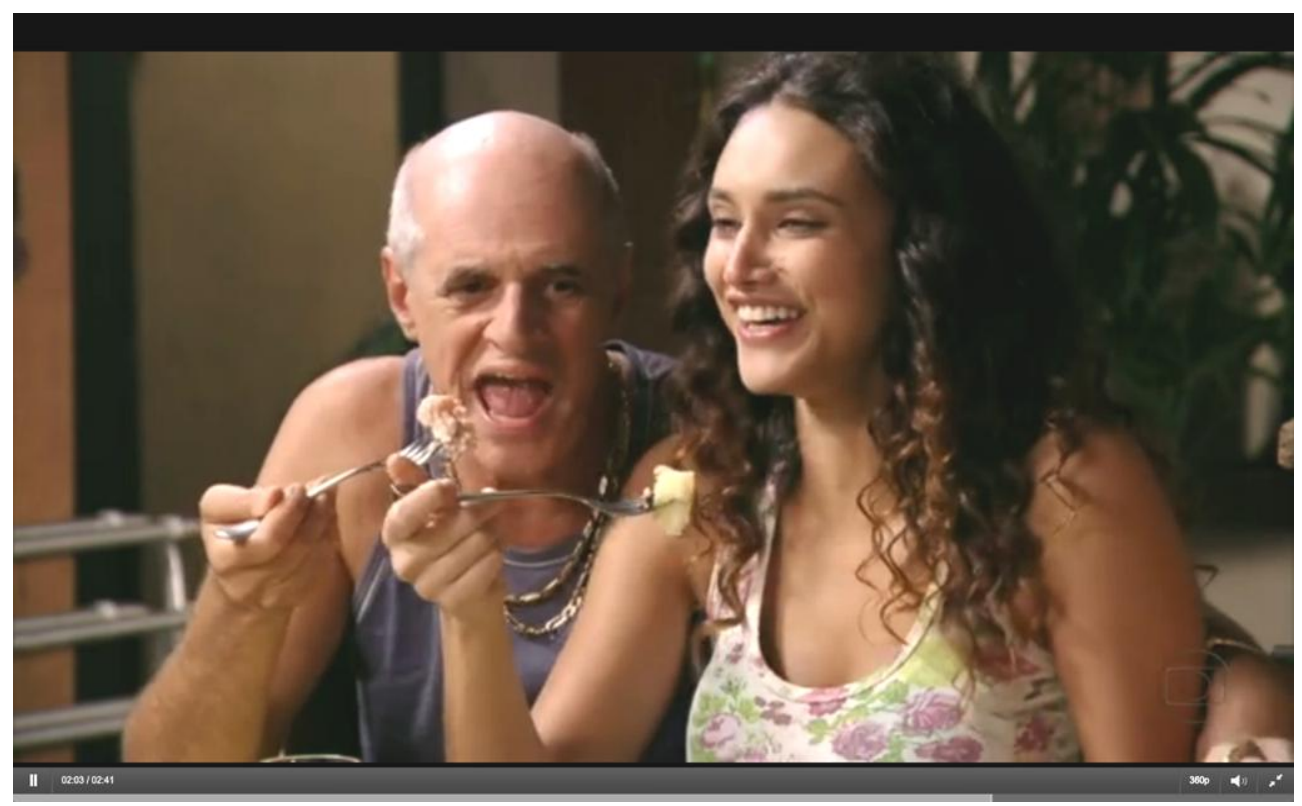

Figura 5 - Leleco e Tessália se divertem à mesa Fonte: <http:/gshow.globo.com/novelas/avenida-brasil/capitulo/2012/7/23/nilo-afirma-quemax- esta-apaixonado-por-nina.html> 
Porém, na hora de lembrar o nome do peixe que Nina costuma preparar, Ivana se atrapalha. Trata-se do prato peruano ceviche como Jorginho pronuncia. Muricy também se confunde, pois vichisua é uma sopa de alho poró, e a sopa fria à qual ela se refere seria o gazpacho. Quando Jorginho lembra o nome da comida, o samba que começa a tocar indica um momento feliz, já que Jorginho apresenta uma aparente melhora da falta de memória.

Assim, mesmo não estando presente, Nina é evocada por seus conhecimentos culinários. A família aparenta gostar da comida da moça, embora ela seja mais sofisticada do que eles estavam acostumados. É evidente que se trata de pratos não familiares para eles pelo fato da não lembrança dos nomes e das associações erradas, bem como ocorre em outros momentos da trama. Porém, Ivana revela gostar mesmo é de um "bom peixinho na brasa", de uma sardinha frita, prato considerado mais simples.

Leleco faz um trocadilho para demonstrar em tom de brincadeira que a comida de Muricy não é tão boa quanto a de Nina, "lá é ceviche. Aqui, cê vê e fala vixe". A expressão "vixe" pode demonstrar surpresa e, nesse caso, pelo contexto, seria uma surpresa ruim. O tom é de brincadeira, há gargalhadas. Mas, Muricy se enfurece e joga o guardanapo no ex-marido, acertando o peixe espetado no garfo, que estava parado no ar enquanto ele falava. Mais uma vez o ambiente é de bagunça e comédia.

Leleco também utiliza vocabulário popular para se referir a Max, como "bundão" e "bundinha". Ele usa a palavra no diminutivo em um segundo momento como se isso fosse aliviar o fato de Ivana ter ficado magoada. A atriz levanta da mesa, fala e chora ao mesmo tempo, simulando um drama que é cômico também, pois demonstra os exageros da intimidade em família.

Momentos antes, Ivana traz uma lembrança familiar, da última vez em que sua mãe Muricy entrou na cozinha para fazer um jantar para os pais da personagem Débora. Essa passagem reforça o fato de eles serem uma família e terem histórias para contar, como o episódio relatado que, segundo Tufão, ocorreu na década de 1980. A cena faz referências a outros acontecimentos passados mais recentes, como os pratos preparados por Nina, e o fato da cozinheira ter ensinado Ágata a preparar um peixe.

A apresentação dessas recordações revela um entrosamento familiar, uma conversa corriqueira entre pessoas que se conhecem bem. Esses elementos são 
reforçados pelos personagens com as falas “... separaram, mas ainda é família”, “A gente é família...”.

Alguns elementos nos remetem a papéis familiares tradicionais. Muricy tem a postura da mãe da família que cozinha e serve os pratos, junto da filha Ivana. Os homens não ajudam, embora Tessália também não participe, assim como Ágata, que é criança. Tufão senta na cabeceira da mesa, como na primeira cena analisada, demonstrando, de certa forma, ser o chefe da família. Apesar da presença de Leleco, que é o mais velho, Tufão é o homem que enriqueceu com o futebol e o dono da mansão, por exemplo. Ágata também senta na cabeceira da mesa, de frente para o pai.

$\mathrm{O}$ ambiente familiar é reforçado também pelo fato de todos se sentirem à vontade a ponto de brigarem sem causar estranhamento, ou levantarem da mesa como Jorginho e Ivana e, mesmo assim, todos continuarem a conversar sobre assuntos corriqueiros.

É conveniente ressaltar que Jorginho fala poucas vezes no trecho exposto, a última vez é quando ele declara ter perdido a fome. Não há referências a ele na maior parte do tempo, o que revela que a função narrativa da cena, enfatizada pelo nome dado ao site "Jorginho não se lembra de Cadinho", não é o mais importante, sobressaindose o momento descontraído e cômico entre os personagens.

O trecho ilustra um momento familiar, assim como o primeiro fragmento analisado na sala de jantar da mansão, em que a referência a Janaina só é feita no final, justificando o título "Carminha reclama da comida de Janaina".

Desse modo, na significação identificacional, temos o ethos popular e o ethos cômico, assim como no primeiro trecho analisado. A popularidade ainda é reforçada pelo fato de não haver as contradições presentes na primeira cena. Os personagens se encontram na casa de praia que Tufão já possuía antes de se casar com Carminha e comprar a mansão. É uma casa simples que não fora reformada como era esperado. Além disso, não há empregados na residência nem referências ao enriquecimento da família.

A popularidade está nas brincadeiras, nas falas coloquiais e altas, na informalidade do ambiente, na exposição da intimidade, nas latinhas de cerveja e na postura relaxada à mesa, assim como nas roupas, como as de Leleco e os trajes de banho aparentes de Muricy e Ivana. As referências gastronômicas também indicam popularidade, assim como os erros cometidos por Adauto e o trocadilho de Leleco. 
Nessa cena não há ironia, pois não existe a intenção de mostrar as contrariedades do enriquecimento repentino. Como Carminha não está presente não há citações religiosas, o falso moralismo e a pretensão burguesa. Por outro lado, é perceptível uma maior demonstração de intimidade e familiaridade, como a expectativa do almoço quando Tufão e Ágata aguardam o peixe ficar pronto sentados no sofá e Adauto e Ivana falam da mesa posta, entre outros aspectos já explicitados.

Assim, é possível falar também de um ethos familiar que opera, é razoável sugerir, com a identificação do telespectador do que é vivenciado como um momento de família.

A esse respeito temos a noção de incorporação para designar a ação de ethos, abordada por Maingueneau (2004). O autor explica que o co-enunciador é incitado a conferir um corpo ao fiador do discurso, ele assimila um conjunto de esquemas que definem para um dado sujeito - no nosso caso a família ficcional de Tufão - uma forma específica de se inscrever no mundo.

Tudo isso permite a constituição de um corpo "[...] o da comunidade imaginária dos que comungam na adesão a um mesmo discurso" (MAINGUENEAU, 2004, p. 100). Assim, é possível propor que essa cena familiar, por todos os elementos abordados, "forma um corpo" com aqueles que vivenciam ou já vivenciaram situações familiares similares.

Já no nível representacional - com as indicações dos ethé cômico, familiar e popular - temos o discurso de uma família popular que é unida e feliz a seu modo. $\mathrm{O}$ peixe queimado, por exemplo, não se configurou um problema. Todos brincaram e comeram, com exceção de Jorginho, que permaneceu quieto.

O drama e os desentendimentos não se configuram em problemas, na forma que a cena é transmitida. Eles fazem parte da maneira de ser dessa família que é popular, apesar do enriquecimento. O habitus e o capital cultural são da classe de origem.

Essa cena isolada, sem referências à prática discursiva, não revela que eles são ricos. Há apenas uma fala que pode ser considerada um indicativo da condição financeira da família, que é quando Muricy afirma que a cozinheira não veio e por isso ela resolveu fazer um peixe.

O que se sobressai no discurso da cena é a demonstração das disposições sociais no seio familiar. Ou seja, a postura popular e o baixo capital cultural estão atrelados à 
herança de família e não dizem repeito a atributos individuais. A família assume um papel importante nessa cena.

Jessé Souza (2012) explica que existe nas disposições da nova classe trabalhadora um capital familiar, ou seja, a transmissão de exemplos e valores do trabalho duro e continuado.

Se o capital econômico transmitido é mínimo, e o capital cultural e escolar comparativamente baixo em relação às classes superiores, média e alta, a maior parte dos batalhadores entrevistados, por outro lado, possuem família estruturada, com a incorporação de papéis familiares tradicionais de pais e filhos bem desenvolvidos e atualizados. (SOUZA, 2012, p. 50).

$\mathrm{Na}$ cena, existe o relacionamento com papéis familiares tradicionais. Mas, as referências ao trabalho são diferentes, pois Tufão enriqueceu com o futebol. De qualquer modo, temos na prática discursiva da narrativa, o exemplo de Muricy que era empregada doméstica e camelô e Ivana que se dedica à administração da rede de cabeleireiros e é bastante econômica.

Adauto, por exemplo, apesar de não ser da família de fato, trabalhava como gari e se mostra uma pessoa trabalhadora, pois mesmo podendo desfrutar do conforto proporcionado por Muricy, ele não consegue ficar parado e aparece em algumas cenas trabalhando em obras e arrumando a casa, por exemplo. Esses elementos dialogam com o que na prática social é considerado próximo da realidade da nova classe trabalhadora, de acordo com Jessé Souza (2012).

Porém, uma formação discursiva não é um bloco homogêneo como argumenta Maingueneau (2004), ela é heterogênea e composta por diferentes discursos e, nesse caso, não é diferente, pois é possível identificar também aspectos de um discurso que se assemelha ao que Souza (2012) argumenta como racismo de classe e também ao individualismo neoliberal.

Há a figura de Jorginho que destoa de sua família, ele não apresenta as mesmas características populares, indicativo de que seu comportamento seria um aspecto individual, desvinculada da herança familiar e de classe.

Além disso, o discurso atribuído a Leleco se assemelha à figura do malandro e, consequentemente, ao racismo de classe (SOUZA, 2012), pois o personagem, além de toda sua construção corporal (trejeitos e roupas), nunca está vinculado a situações de trabalho desde os primeiros capítulos e é conectado ao gosto pelo bar e pelo jogo de sinuca. 
No site oficial da trama, Leleco é descrito como um ex-lutador de Box, amável, boêmio e também como malandro: "Depois que seu filho ficou rico com o futebol, o malandro parou de fazer bicos e caiu de vez na folia" 16 .

A figura do malandro faz parte do pensamento da instrumentalidade que, para Souza (2012), junto do arcaísmo patriarcal, configura um racismo em relação às classes populares. O arcaísmo patriarcal é representado pelo pertencimento dos membros da família a uma rede de benefícios pessoais dentro de uma hierarquia. A instrumentalidade, por sua vez, sugere que os laços familiares estão pautados na instrumentalidade do outro, na possibilidade de tirar vantagem dos familiares consanguíneos ou não.

O autor afirma que essas características são reforçadas pela mídia por meio das telenovelas e também por programas de humor como A Grande Família.

Essas duas características são complementares porque, ao se desclassificar as relações familiares, da esfera privada, como baseadas em uma rede de benefícios pessoais e instrumentais, legitima-se a suposta inaptidão das classes baixas à esfera pública [...]. (SOUZA, 2012, p. 123).

O arcaísmo patriarcal não é forte na representação familiar de Avenida Brasil, porque a autoridade de Tufão não é marcada o suficiente, as mulheres têm voz ativa na família. Nessa cena, Tufão fala pouco e não demonstra mais autoridade que Ivana (que cuida dos negócios da família, é importante frisar) na repreensão aos pais, por exemplo.

Já a instrumentalidade encontra respaldo em Leleco, de um modo geral. Apesar disso, é possível dizer que o discurso principal da cena traz, com um viés cômico, o papel da família na reprodução das disposições populares.

Dito isso, partiremos para a próxima cena "Muricy reclama de filme indicado por Nina". Ela tem início com o enquadramento da personagem Muricy sentada no sofá com as pernas encima dele, descalça. Ela usa um vestido com estampa de onça e assiste à televisão com o controle remoto na mão.

16 Disponível em: <http://gshow.globo.com/novelas/avenida-brasil/personagem/leleco-marcoscaruso.html\#perfil>. Acesso em: abr. 2014. 


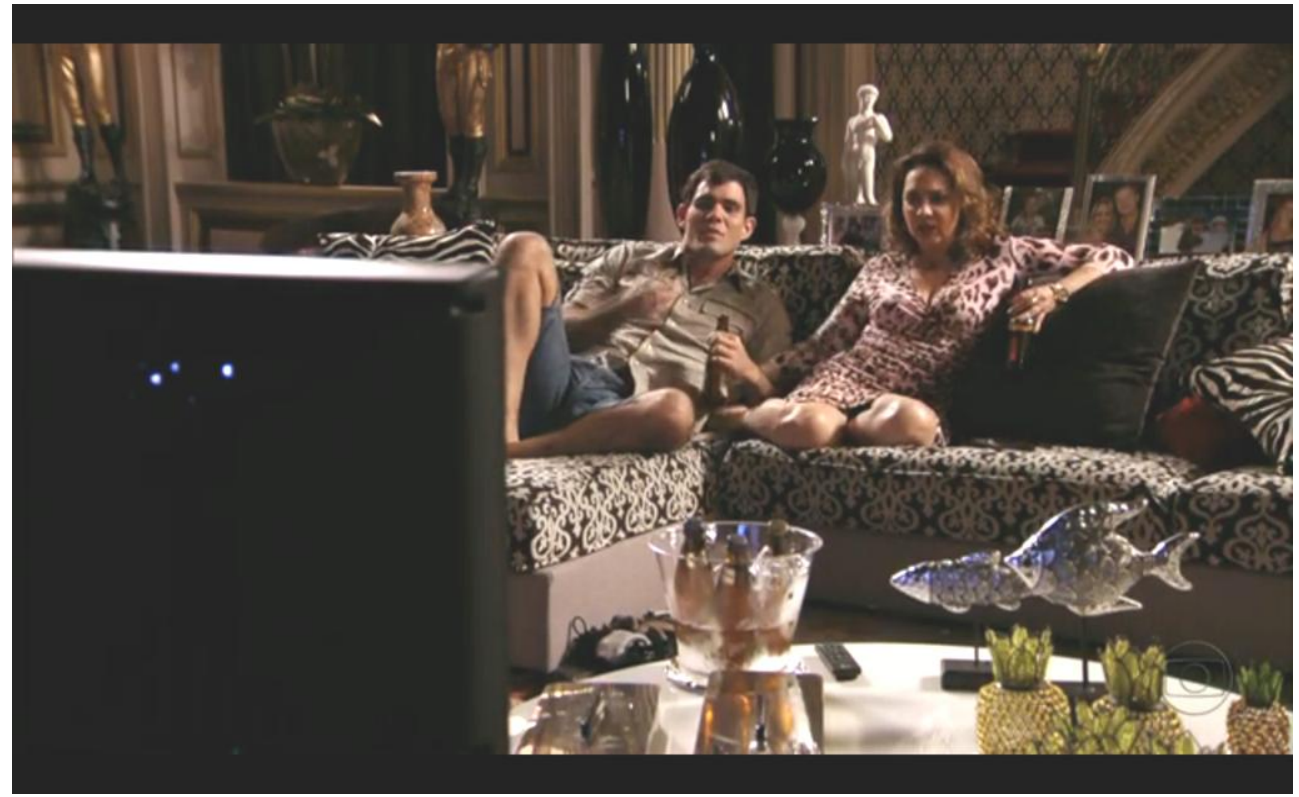

Figura 6 - Muricy e Adauto discordam sobre o filme que estão assistindo Fonte: <http://gshow.globo.com/novelas/avenida-brasil/capitulo/2012/9/17/nina-deixa-claropara-tufao-que-ama-outro-homem.html>

Muricy: "Isso sim que é filme bom, ó só, filme de ação, isso aqui prende a gente!".

Adauto chega à sala com um balde de cerveja e contraria a afirmação de Muricy: "Que prende".

Muricy: “Aquele outro filme é chato pá caramba. Aquela gente chata que só fica se olhando, suspirando, não tem barraco!”.

Adauto: "Esse filme aí é que é ruim, entendeu? Só bebendo. Trouxe até uma cerveja pá gente tomar. Aí ó. Só tem pancadaria, sacou, não tem história. Aquele outro pelo menos lá eu tava gostando do filme..." - ele abre a garrafa de cerveja de Muricy com a ajuda do tecido da sua camisa - “... queria saber se aquela mulher, inclusive, arranjou um home pra chamar de dela, alguma coisa assim...”.

Muricy: "Nada, nada, esse filme aí que é bom. Aquele outro deve ter sido aquela chata de galocha que indicou, né. Eu não sei o que tanto cês veem de graça naquela menina. Como é que era o nome daquele diretor lá chato do filme branco e preto?”.

Adauto: "Bellini."

Os dois tomam cerveja, quando entra Tufão na sala.

Tufão: "Quem que é Bellini? Bellini é...".

Muricy: "O diretor daquele filme chato lá.".

Tufão: "Que diretor, mãe, o Bellini é...". 
Adauto: "É, o Bellini.".

Tufão: “... era capitão da seleção campeã de 58, zagueiro.”.

Adauto indaga com surpresa: "E dirigia filme tamém?".

Tufão, se aconchegando no sofá: "Não! Ai, meu Deus do céu. Fellini que dirigiu aquele lá que a gente tava vendo.”.

Adauto: "Então, Fellini.".

Tufão: "Uma coisa é Bellini, outra coisa é Fellini, seu Adauto.”.

Adauto: "Ah, o outro é Bellini.".

Muricy pega o controle e desliga a televisão enquanto fala: "Filho, ó, sabe o que que eu acho? Cê tem que parar de perder tempo de assistir esses filme branco e preto e cuidar melhor da sua esposa, da Carminha, né, filho.”.

Leleco abre a porta da casa e entra: "Que esposa? Ouvi falar de sua esposa. É exxxx (ele reforça o ex) esposa. Meu filho tá separado... Tufão separou da Carminha. É impressiona (não termina a palavra)... as pessoas vão ficando mais velha, vão ficando esquecida, não é não?”.

Muricy: "Elas vão. Você, por exemplo, esqueceu que cê não mora mais aqui, né?".

Adauto: "Toooma!".

Leleco: "Não moro mais aqui...".

Muricy: "Tá penando que isso aqui é o que, a casa da sogra?”.

Leleco: "Graças a Deus eu não tenho sogra. Graças a Deus, desde que a bruaca da tua mãe empacotou...”.

Muricy fala ao mesmo tempo em que ele, com indignação: "Olha aqui, não fala da minha mãe!".

Leleco: “... ela empacotou, graças a Deus, tá de braços dados lá com o demo (não termina a palavra)... com o capeta." - ele faz sinal para o alto.

Muricy fala ao mesmo tempo, com ironia: "Não, a minha sogra que era ótima, né?".

Leleco: "Aqui, aqui é a casa do meu filhooo.".

Tufão: “Oh, pai, falando nisso, vem cá, tu chegou a sair do pôquer... tava ruim o baile?".

Leleco: “O baile não... já me dá dor de cabeça pensar naquele baile, já tinha... já deu o que tinha que dar.". 
Leleco em tom mais animado: "Muricy?".

Muricy: “Ah?”.

Leleco bate uma mão contra a outra de leve: "Você, tu podia fazer aí uma beberagem aí com aquelas ervas sete grão aí, que tu faz...”.

Muricy olhando para Adauto: "Mas, olha que folgado. Ele já chega dando trabalho pra gente. É mole?".

Leleco: "Faz pá mim?”.

Muricy: "Faz pra mim o que, meu filho, vai lá dentro fazer você.".

Leleco: "Dá trabalho, o que dá trabalho? Fazer chá dá trabalho?" - ele ri com deboche.

Adauto: "Ué, se não dá trabalho, por que que tu não faz então?."

Leleco: "Eu?".

Adauto: "Fica aqui pedindo pra mulher dos oto?".

Leleco: "Qual é o problema rapá?".

Adauto: "É, vai fazer seu chá, meu amigo.".

Leleco: "E tua mulher não faz por quê? Ta vendo filme?".

Adauto: "É".

Leleco: "Filme dá trabalho. Dá muito mais trabalho que fazer chá, principalmente se o filme for de adulto né, porque aí tu tem que explicar pra Adauto.”.

Muricy: "Ai, meu Deus do céu!".

Leleco gargalha.

Tufão se levanta: "Vamos lá pá cozinha, pai. Vamos lá pá cozinha, que eu vou fazer um chá pá você.”.

Muricy: “Isso, vai lá. Vai lá!”.

Leleco se levanta: "Vou fazer meu filho fazer chá.".

Tufão fala algo ao mesmo tempo e Leleco murmura algo.

Muricy: "Explica pro teu pai lá que você foi pra delegacia perder seu tempo, tentando tirar aquela emaconhada de lá...”.

Tufão fala se retirando do ambiente: "Perder tempo não, entendeu? Porque a Nina é inocente. Tu num começa. Quando você bota alguma coisa na cabeça...”.

Muricy: "Aham. Pó deixar. Cara, eu vou fazer uma novena pra santa Terezinha, pá aquela paquita erótica de Macacu aceitar esse cacareco de volta.”.

Adauto: “É, ainda bem. Porque tá chato pá caramba esse Leleco aqui...”. 
Muricy: "Insuportável.”.

Adauto: "Toda hora aqui na nossa casa, entendeu?".

Muricy: “Alá, vamos voltar assistir o filme, amor. Isso que é bom, esse filme que é bom, ó.”.

Adauto: "Por que que a gente não volta pro filme do Bellini?" - Ele se ajeita no sofá, colocando os pés no estofado também.”.

Muricy: "Porque não. O Bellini não faz filme bem, ele joga bola só. Filme ele faz que é uma porcaria.”.

Adauto: "Esse filme aí não tem nada di...".

Muricy: "Esse é bom. Não, esse é bom. Olha uma coisa, ó.”.

Adauto: "Amor!".

Muricy: "Ei, explodiu tudo. Olha, que delícia.” Risos.

Adauto: "Que porcaria.”.

Muricy: "A cabeça do cara foi parar do outro lado da rua.".

Ao mesmo tempo Adauto exclama: "Olha o olho. Que nojento esse olho!".

Muricy: "Aha! Adoro!".

Adauto: “Tá vendo? Não tem negócio de emoção.”.

Muricy: “Ai quanto sangue. Ai, que delícia. Adoro isso.”.

$\mathrm{Na}$ significação acional dessa cena também temos a simulação de um gênero primário de diálogo informal entre o casal Muricy e Adauto, sobre o filme que estão assistindo. Depois, Tufão e Leleco são adicionados à conversa. A informalidade da cena é reforçada no início por Muricy descalça, com as pernas em cima do sofá. Ela olha para a televisão e demonstra satisfação com o filme de ação que "prende a gente". Mas é contrariada por Adauto que, inclusive, traz um balde de cerveja para aguentar assistir ao filme. O ritual de assistir à televisão e o consumo cultural se tornam palco para apresentar o horizonte dos gostos culturais e o repertório em que os personagens se envolvem.

Eles fazem referência a outro filme que haviam visto em outra cena. Na verdade, as falas de Adauto revelam que eles não terminaram de vê-lo. Muricy se refere a ele como "chato pá caramba", pois, segundo ela, os personagens são chatos e só ficam se olhando, não tem "barraco".

Trata-se de uma produção do diretor italiano Federico Fellini, indicado à família por Nina, à qual Muricy intitula "chata de galocha". Muricy não se lembra do nome do 
diretor Fellini, reforçando a ideia de que ela desconhece a obra do artista, assim como Adauto, que confunde o nome com Bellini.

A cena traz a questão do gosto e consumo cultural à tona. É evidente uma resistência de Muricy à cultura considerada legítima, representada pelo filme de Fellini, o que pode ser interpretado como incompreensão. Ela considera assistir esses filmes uma perda de tempo quando recomenda ao filho: "Cê tem que parar de perder tempo de assistir esses filme branco e preto e cuidar melhor da sua esposa, da Carminha, né, filho".

Por outro lado, ironicamente, Adauto, que é considerado ignorante pelos outros integrantes da família, apresenta simpatia pelo filme de Fellini e aversão ao filme de ação que agrada Muricy, pois para ele esse último só tem pancadaria e não apresenta uma história. Ele expressa curiosidade em saber o final do filme de Fellini, se a personagem "arranjou um home pra chamar de dela, alguma coisa assim...".

A fala de Adauto não revela conhecimento nem reconhecimento cultural do filme, mas sim um interesse genuíno. O reconhecimento cultural, segundo Bourdieu (2007), diz respeito à legitimação conferida pelas classes populares e médias aos produtos das classes dominantes, revelando um desejo de pertença às classes mais altas e uma forma também de camuflar a ignorância quanto aos produtos considerados legítimos que não fazem parte de fato de seu universo.

Quando o casal confunde o nome do diretor Fellini, Tufão entra na sala e explica que Bellini era um jogador de futebol. A surpresa de Adauto, que acredita por um momento que o jogador também dirigia filme, traz comicidade à cena. As falas do personagem são bastante coloquiais e apresentam problemas de pronúncia, como "sacou”, "tamém". "tooma”, “dos oto", “home”.

Os outros personagens também utilizam expressões coloquiais e Muricy e Leleco apresentam problemas de concordância, por exemplo: “é mole?”, “rapá”, “emaconhada", "ervas sete grão", "as pessoas vão ficando mais velha, "esses filme preto e branco". A informalidade também está presente nos personagens tomando cerveja long neck no gargalo.

Leleco aparece na casa de surpresa, abre a porta e já se introduz na conversa, sentando-se relaxadamente na poltrona da sala. Ele ainda pede para Muricy fazer um chá para ele, demonstrando seu jeito folgado e relaxado. Assim como nas outras cenas, há provações entre Muricy e Leleco, que são encenadas de maneira engraçada. Leleco ri 
com deboche das próprias piadas, faz referências à ex-sogra já falecida e aponta para o céu quando fala de inferno. Muricy rebate a provocação. Há, desse modo, exposição de privacidade e tom de comédia.

Inclusive, Muricy deseja que Tessália, chamada por ela de "paquita erótica", aceite o "cacareco" de volta para que, assim, ela possa ter sossego novamente. A primeira expressão, que é empregada em referência às assistentes de palco do programa de televisão infantil Xou da Xиха (transmitido na Rede Globo entre as décadas de 1980 e 1990), já fora utilizado em outras telenovelas da Rede Globo. A expressão “cacareco", por sua vez, é utilizada para expressar que Leleco é velho e não tem mais serventia.

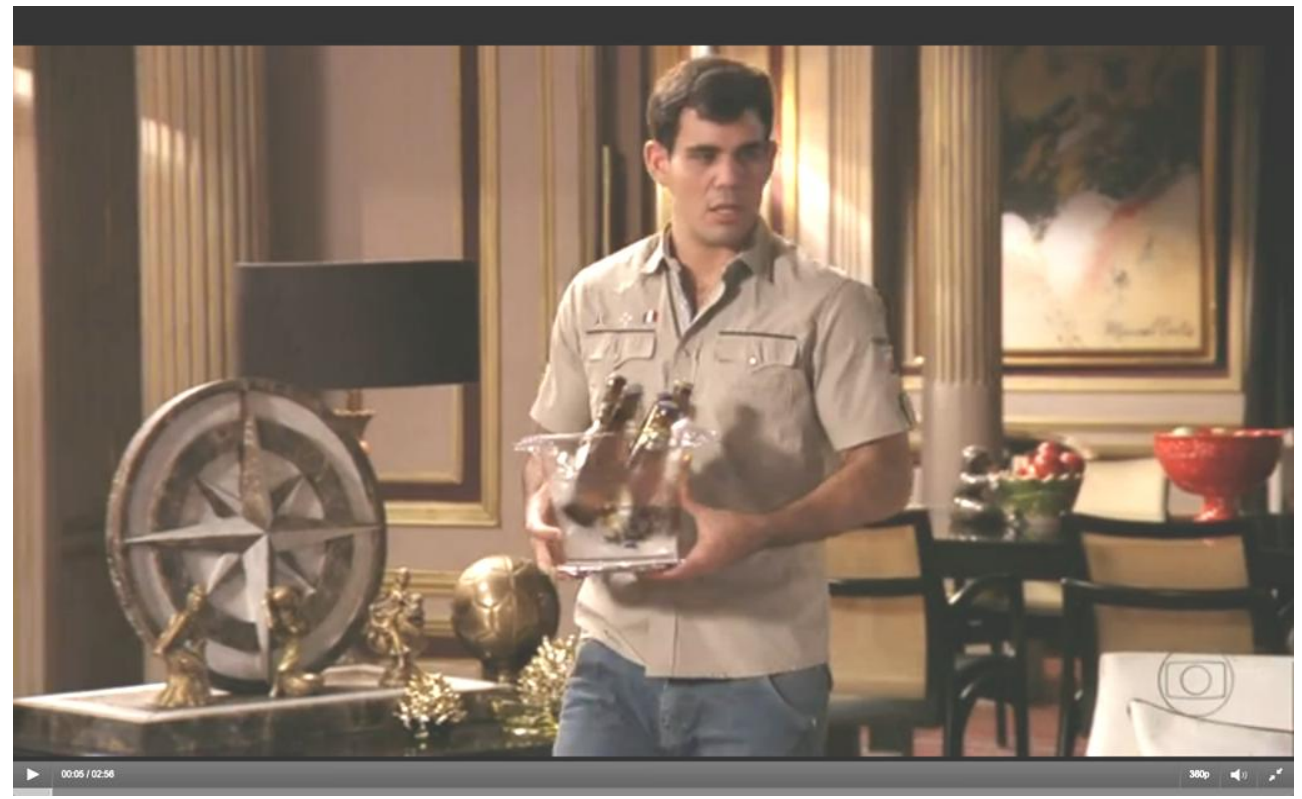

Figura 7 - Adauto traz cerveja para ele e Muricy tomarem enquanto assistem ao filme. Fonte: <http://gshow.globo.com/novelas/avenida-brasil/capitulo/2012/9/17/nina-deixa-claropara-tufao-que-ama-outro-homem.html>

Já a afirmação de Muricy que fará uma novena a Santa Terezinha indica certa religiosidade da personagem, porém a menção é feita de forma corriqueira, dentro de um contexto específico, diferente da apelação moral da personagem Carminha.

A referência a Nina como "emaconhada" se dá pelo fato de Nina ter sido encontrada com maconha. Na verdade, foi uma armação contra a moça, mas Muricy não acredita e critica o fato do filho ter ajudado a moça a sair da cadeia. A construção de Muricy, de uma forma geral, é de uma personagem repleta de ideias pré-concebidas, teimosa e ignorante também.

Nessa cena em questão, Leleco também debocha de Adauto ao afirmar que assistir a um filme pode dar trabalho a Muricy, porque se for de adulto ela terá que explicar 
para Adauto. $\mathrm{O}$ engraçado dessa cena é que anteriormente Adauto estava reclamando do filme de ação que agrada Muricy e queria ver Fellini, cuja produção é considerada complexa intelectualmente.

Além disso, Muricy e Adauto demonstram não terem entendido a explicação de Tufão sobre Fellini e Bellini, porque no final da cena, ambos retornam a fazer referência a Bellini como diretor de filme e também jogador de futebol, trazendo, mais uma vez, um viés cômico à tona.

No trecho analisado, o cenário da mansão novamente tem destaque. Logo nos primeiros segundos, a estampa do sofá junto da estampa de onça do vestido de Muricy chamam a atenção. Também há os aspectos decorativos já discutidos, como as miniaturas de abacaxi em cima da mesa de centro, peixes ornamentais, vasos e estátuas espalhados pela casa e muitos detalhes dourados. Outra mesa, focalizada durante a gravação, comporta uma rosa dos ventos decorativa e muitos objetos dourados. Atrás de Muricy e Adauto, há um móvel que abriga vários porta-retratos, nos quais é possível distinguir a fotografia de Max e Ivana juntos e de Ágata.

Há, assim, as contradições do cenário que se pretende pomposa, mas transmite o exótico, e destoa da popularidade dos personagens presentes. Embora, o vestido de Muricy, nessa ocasião, seja condizente com o cenário. Porém, ao contrário da primeira cena analisada, a ironia aqui não é evocada como no discurso falso moralista de Carminha e em sua compostura forçada. Não há fingimento, há espontaneidade o tempo todo neste trecho.

A discussão sobre o filme tem destaque. Existe a ignorância em relação a filmes considerados da cultura legítima e também a ironia deste tipo de filme atrair Adauto, o personagem considerado ignorante dentro de uma família popular que também demonstra ignorância em muitos assuntos.

$\mathrm{Na}$ verdade, o filme de ação assistido por Muricy e o filme de Fellini são colocados no mesmo patamar quando os dois discutem qual é o melhor. Muricy afirma que o de ação é bom porque prende a atenção, e Adauto alega falta de emoção e de história nos de ação e, por isso, demonstra preferir o de Fellini.

Os dois tratam nessas falas, de algum modo, de sensações provadas pela experiência no consumo cultural dos filmes e de um gosto atrelado a situações cotidianas, no caso de Adauto, e a representações de ação e violência bastante 
explícitas, no caso de Muricy que se sente atraída pelas cenas de sangue, olho estourado e cabeça rolando.

Para analisar tal questão, é pertinente trazer à discussão a distinção que o sociólogo Bourdieu (2007) faz entre a estética popular e a estética das classes abastadas que tiveram maior contato com o capital cultural considerado legítimo. O teórico explica (2007) que o gosto popular enxerga a estética por ela mesma, dissociada de uma função, de um conteúdo claro. A tendência é associar a arte com a própria vida, sem uma distinção entre forma e conteúdo. "Seja no teatro ou no cinema, o público popular diverte-se com as intrigas orientadas, do ponto de vista lógico e cronológico, para um happy end [...]" (BOURDIEU, 2007, p. 35).

$\mathrm{Na}$ cena analisada, além da estética popular, percebe-se que não há a intenção de pertencimento à cultura dominante, pois não existem indícios de reconhecimento cultural do filme de Fellini pelos personagens.

Embora Tufão apareça como uma voz didática para desfazer a confusão entre quem é Bellini e Fellini, ele dá destaque na explicação a Bellini e depois diz que quem dirigiu o filme assistido era Fellini, sem entrar em detalhes e maiores apresentações sobre o diretor. A legitimação cultural de Fellini só pode ser presumida pelo conhecimento do próprio telespectador e, por meio da narrativa, por ter sido uma indicação da personagem Nina, a moça culta.

Assim, temos nessa cena, na significação identificacional, além dos ethé cômico e popular, o ethos da estética cotidiana, justamente pelo fato da arte aqui estar associada às sensações gerais da vida. É plausível também sugerir que a comparação entre Bellini e Fellini traz um discurso que coloca o futebol e o cinema - o popular e mundano e o considerado culto e legítimo pela camada dominante da população ${ }^{17}$ - no mesmo patamar. Ideia essa reforçada no final, quando Muricy e Adauto continuam confundindo os dois. Tal dado pode ser interpretado também como um questionamento quanto à necessidade de reconhecimento da cultura considerada legítima por parte da classe popular sem que de fato haja conhecimento.

Desse modo, na significação representacional dessa cena, temos um discurso que mostra a popularidade, por um viés cômico, de um gosto estético atrelado ao consumo de bens e produtos culturais, desvinculados do julgamento cultural considerado legítimo

17 É pertinente esclarecer que a classe dominante não é considerada aquela com o maior número de cidadãos, mas sim a que possui acesso privilegiado a tudo, como capital cultural e econômico. (SOUZA, 2012). 
e dominante, pois os personagens principais da cena apresentam o capital cultural de sua classe de origem, não conhecem e não reconhecem a cultura dita legítima e exprimem um modo próprio de ver a obra de arte, no caso os filmes discutidos.

É interessante ressaltar que das cenas analisadas essa foi a única em que o nome atribuído pelo site "Muricy reclama de filme indicado por Nina" condiz com o conteúdo principal, ou seja, com a temática corriqueira da conversa e não se referia a um dado narrativo apenas citado.

Assim, terminamos a análise das três cenas de Avenida Brasil. Elas mostraram a predominância do ethos popular e cômico. De um modo geral, a representação discursiva dialogou com o que Jessé Souza (2012) atribui às novas classes trabalhadoras em sua pesquisa, apesar da reprodução de algumas posições hegemônicas do racismo de classe.

As cenas selecionadas retrataram usos e consumos (alimentares e culturais, sobretudo), conversas bastante corriqueiras e informais, sem relação direta com a narrativa como um todo. Junto a isso, as falas altas e ao mesmo tempo reforçaram o tom popular. Embora haja a necessidade de um maior aprofundamento, é possível sugerir a existência de uma inovação na representação do gênero primário dentro de Avenida Brasil em decorrência dos dados explicitados, pois os gêneros discursivos são convenções que também se renovam (BAKHTIN, 2003; FAIRCLOUGH, 2003).

Analisaremos, agora, as cenas de Cheias de Charme e detalharemos os resultados da análise de Avenida Brasil nas conclusões da presente dissertação, em comparação com a análise que será levantada a seguir.

\subsection{CONTEXTO NARRATIVO DE CHEIAS DE CHARME}

A telenovela Cheias de Charme, de Filipe Miguez e Izabel de Oliveira, foi transmitida pela Rede Globo, no horário das 19 horas, do dia 16 de abril de 2012 a 21 de setembro do mesmo ano (no sábado, 22 de setembro, houve a reprise do último capítulo). A trama, que se passa no Rio de Janeiro, totalizou 138 capítulos e contou com 41 personagens, de acordo com o site oficial da telenovela. ${ }^{18}$

\footnotetext{
${ }^{18}$ Disponível em: <http://gshow.globo.com/novelas/cheias-de-charme/index.html.>
} 
As protagonistas são três empregadas domésticas: Maria Aparecida (Isabelle Drummond), Maria da Penha (Taís Araújo) e Maria do Rosário (Leandra Leal). Também tem destaque a personagem Chayene (Cláudia Abreu), uma geniosa cantora de eletroforró, que costuma ter ataques de estrelismo e maltratar suas empregadas domésticas. Apesar disso, o papel tem um forte caráter cômico, assim como Fabian (Ricardo Tozzi), o sedutor cantor de sertanejo universitário, que é considerado o “príncipe das domésticas".

Cheias de Charme assume em sua trama a oposição entre empregadas domésticas e patroas, que se desentendem, brigam (de forma bem humorada ou não) e até tornamse amigas, como ocorreu com Maria da Penha e Lygia (Malu Galli). É pertinente destacar que o condomínio onde as três patroas principais da trama residem - Chayene, Lygia e Sônia (Alexandra Richter) - se chama Casa Grande, em uma alusão à obra de Gilberto Freyre Casa Grande \& Senzala (2006).

Durante a trama, o desentendimento entre patroa e empregada é frequente. A justiça é acionada, inclusive, para resolver os casos. Mas, em dado momento da telenovela as empregadas mudam de situação financeira e deixam a vida de doméstica. Graças ao sonho de Maria do Rosário de ser cantora, as três gravam um videoclipe com a música "Vida de Empreguete" na casa de Chayene, patroa de Maria do Rosário na ocasião, em um momento de ausência da dona da residência. Elas recebem a ajuda do amigo Kleiton (Fábio Neppo), produtor musical e vizinho de Penha na fíctícia comunidade do Borralho.

O videoclipe "vaza" na internet sem o conhecimento das empregadas, que são processadas por Chayene quando esta vê o material. A letra da canção expõe a relação entre empregadas e patroas de maneira divertida, as três imitam suas chefes, o que não agrada as moradoras do condomínio Casa Grande, com exceção de Lygia, que não se enfurece como as outras. As três prestam depoimento e acabam sendo presas por desacato à autoridade, como já ocorrera em outro momento da trama. Porém, elas conseguem ser soltas graças ao poder da internet, pois Elano (Humberto Carrão) e Kleiton promovem uma mobilização a favor do trio, aproveitando o fato do videoclipe ter se tornado um viral. A partir disso, as Empreguetes começam a ficar famosas, a fazer shows e a ganhar dinheiro.

É pertinente pontuar o poder que a internet e outras mídias assumem na trama. Elas podem ser consideradas na narrativa como uma arma contra a invisibilidade e a 
ausência de poder das classes menos favorecidas dentro do sistema político e judiciário brasileiro. O personagem Ernani Sarmento (Tato Gabus Mendes), por exemplo, que é patrão de Maria Aparecida e advogado de Chayene, se manifesta a esse respeito com sua esposa Sônia, afirmando que antigamente prevaleceria o poder dos poderosos, como eles, mas depois do mundo pós-internet a situação parece ser diferente.

Assim como a internet, as empregadas também recorrem, em outros momentos, ao programa de rádio Bom Dia, Dona Maria, do locutor Gentil Soares (Gustavo Gasparini). Nos primeiros capítulos, Penha fornece uma entrevista para o programa, contando que foi agredida por Chayene, por exemplo.

É conveniente destacar a personagem Maria da Penha especificamente, pois ela é a única negra das três empregadas, a que vivencia mais dificuldades (é chefe de família e tem um filho pequeno, Patrick, interpretado pelo ator mirim MC Nicolas), e a única a se intitular exclusivamente como empregada doméstica, ao contrário de Maria do Rosário e Maria Aparecida, que também se denominam, respectivamente, cantora nas horas vagas e estudante. Tudo o que Penha consegue é com o esforço de seu trabalho, ela é batalhadora e alegre. Em dada cena, afirma, por exemplo, que para fazer o "puxadinho" em sua casa, trabalhou vendendo cosmético, fez jantar "pra grã-fino" e cuidou de criança.

Constantemente, Maria da Penha precisa recorrer ao seu irmão Elano, que é advogado e, ironicamente, o único branco da família. Além dele, ela possui outra irmã mais nova Alana (Sylvia Nazaretth). Os três são de pais diferentes. Na verdade, Elano poderia ser do mesmo pai de Penha, mas como o garoto nasceu branco, e o casal era negro, o pai desconfiou da mulher e foi embora sem esclarecer a situação. Alana, a mais nova, é fruto de um relacionamento com um “manguaceiro" (nas palavras de Penha).

A mãe da família foi embora, atrás de outro homem, quando Alana tinha apenas dois anos de idade. A partir de então, Maria da Penha assumiu a responsabilidade de criar os irmãos junto de seu marido Sandro (Marcos Palmeira), que mais atrapalha que ajuda, visto o seu caráter malandro e folgado. Inclusive, Penha o expulsa de casa, eles ficam separados a maior parte da trama, apesar de ele estar sempre presente na casa que era do casal.

Desse modo, Maria da Penha parece ter vindo de uma família pertencente ao que Souza (2012, p. 50) chama provocativamente de "ralé". Trata-se, na explanação do autor, de uma família monoparental, com mudança frequente do membro masculino e 
que enfrenta problemas como o alcoolismo. Ainda assim, o teórico explica que muitos dos batalhadores, que são a nova classe trabalhadora, são oriundos da ralé.

Além disso, Maria da Penha apresenta características da classe trabalhadora que se referem ao capital cultural de origem e ao espírito comunitário (SOUZA, 2012). Ao contrário de Maria Aparecida e Maria do Rosário que parecem dois personagens descontextualizados quanto ao lugar de origem e classe, Maria da Penha se relaciona com a comunidade Borralho, com seus moradores, e apresenta problemas relacionados a uma educação de má qualidade, como os erros de português.

A personagem também é relacionada na trama com a luta pelos direitos das domésticas. Até mesmo ela realiza um site sobre trabalho doméstico com sua ex-patroa Lygia, com a qual grava um comercial em apoio ao registro em carteira, que é veiculado na Rede Globo de 06 de outubro a 20 de outubro de 2012. A propaganda leva a assinatura da Organização Internacional do Trabalho e da Rede Globo. ${ }^{19}$

Ainda assim, conforme exposto no primeiro capítulo, a trama também contribui, em um primeiro momento, para a reprodução da ideologia do desempenho e meritocrática, explicitadas por Ronsini (2012), pois demonstra uma ascensão individualista e uma realidade do emprego doméstico mais próxima das relações pessoais que das de classe. Além disso, há os relacionamentos pessoais como definidores de chances de ascensão, como é o caso de Elano, que é reconhecido por seu bom caráter pelo advogado rico Dr. Otto (Leopoldo Pacheco) e tem, assim, melhores oportunidades no trabalho.

Também em Cheias de Charme é possível visualizar o final feliz que propaga as desigualdades em tom humanizado, ao emitir a mensagem que ser pobre é bom (RONSINI, 2012). No último capítulo, a festa de casamento de Maria do Rosário com Inácio (Ricardo Tozzi) e Maria Aparecida com Elano é realizada na quadra da comunidade do Borralho. Na cena, estão presentes também personagens do núcleo rico, como Lygia, Dr. Otto, que forma um par romântico com sua ex-empregada Ivone (Kika Kalache), entre outros. Todos dançam e parecem felizes.

É perceptível a presença da matriz do romantismo no modo de tratar as desigualdades (JUNQUEIRA, 2009), pois a solução para o conflito de classes é trazida também pelo relacionamento entre personagens do núcleo pobre e do núcleo rico (RONSINI, 2012).

19 Informações disponíveis em: < http://redeglobo.globo.com/novidades/noticia/2012/10/direitos-dosempregados-domesticos-em-filme-com-tais-araujo-e-malu-galli.html>. Acesso em: abr. 2014. 
Ademais, a propagação das desigualdades da trama também está presente no próprio serviço doméstico, pois, embora as Empreguetes deixem o emprego doméstico, elas passam a necessitar do mesmo serviço quando enriquecem, bem como suas expatroas que perdem suas antigas empregadas. É o caso de Maria da Penha que afirma necessitar de alguém para ajudá-la e, quando deixa a casa de Lygia, por exemplo, apresenta uma colega para preencher a função e substituí-la. Isso reforça a perpetuação das desigualdades sociais, sobretudo das desigualdades de gênero, visto que o trabalho doméstico é sempre destinado a uma mulher em condição mais humilde.

Desse modo, com essas explicações da narrativa, temos alguns dados gerais da prática discursiva, da enunciação. Cabe-nos agora adentrarmos nos enunciados selecionados, que são as cenas: "As Marias fazem um pacto", "Penha vibra com a casa reformada" e "Sônia e Máslova ficam horrorizadas com as ironias de Penha".

Iremos transcrever as cenas e as falas para, depois, realizar a análise propriamente dita conforme feito com Avenida Brasil. O mesmo que foi explicado sobre as transcrições em Avenida Brasil vale para Cheias de Charme. Tentou-se preservar a informalidade das conversas, que foram transcritas de acordo com o entendimento possível. Frisamos em itálico os termos de origem estrangeira, alguns nomes próprios, expressões que não formaram uma palavra com sentido, palavras pronunciadas incorretamente ou que não existem (no dicionário e também não são abreviações ou formas coloquiais conhecidas de outros termos), palavras muito coloquiais, palavras repetidas uma seguida da outra, problemas de concordância, ou palavras pronunciadas com ênfase de modo a dobrar uma letra, por exemplo.

\subsection{ELEMENTOS DA REPRESENTAÇÃO DISCURSIVA DA NOVA CLASSE TRABALHADORA EM CHEIAS DE CHARME}

Na cena "As Marias fazem um pacto", as três empregadas estão presas por desacato à autoridade. Elas foram à delegacia por motivos diferentes e lá se conheceram. Como o atendimento estava demorando e o delegado ia atender uma moça que chegou depois delas, as empregadas insinuaram que estava havendo um favorecimento e, por isso, foram presas. 
A cena começa com um close nos pés das três que estão sentadas em um banco, em uma cela da delegacia. Em baixo dos pés das moças, há folhas de jornal. Maria do Rosário à esquerda, está com uma sapatilha preta, Maria da Penha, no meio, com uma sandália de salto transparente e Maria Aparecida usa uma sandália de salto um pouco menor, rosa e branca.

Em seguida, a câmera grava de um ângulo superior, na altura do teto da sala, quando Maria da Penha toma a palavra. Um som acompanha o início da cena.

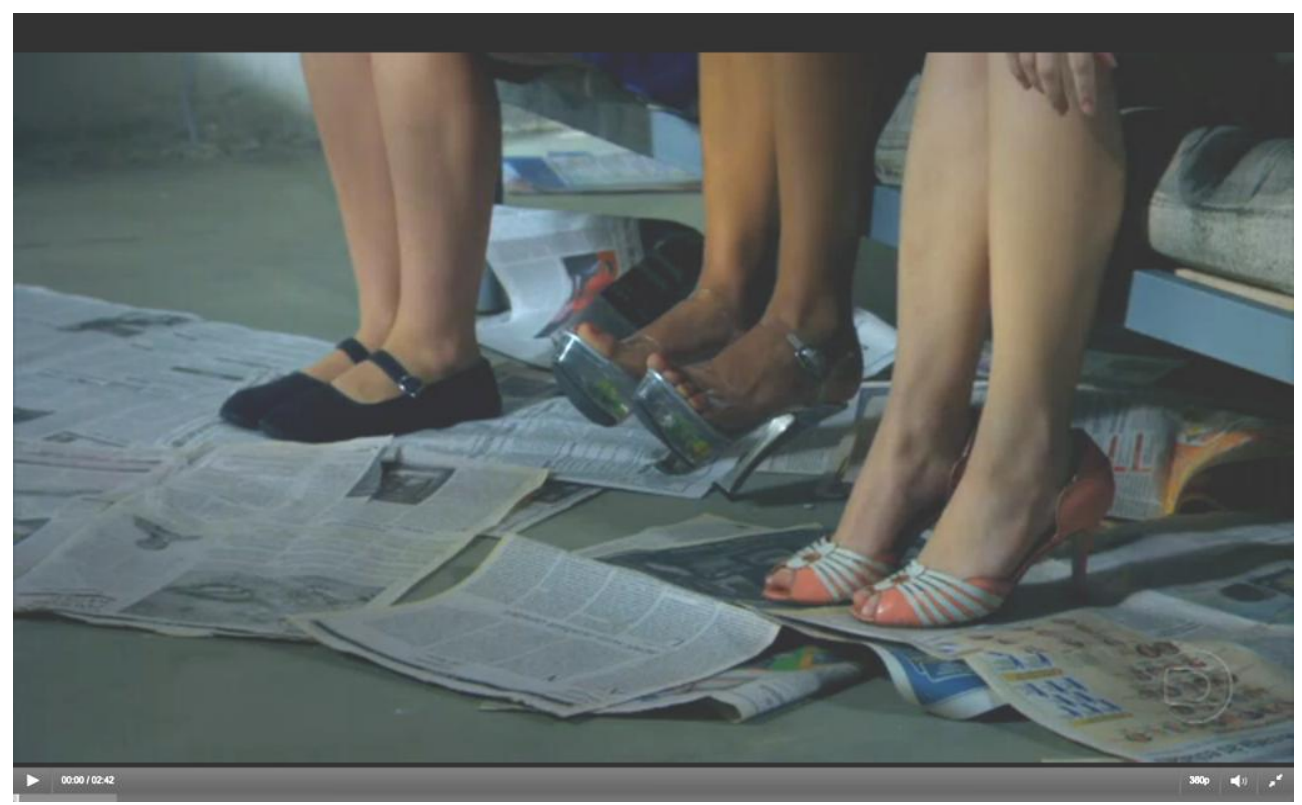

Figura 8 - Close nos pés das três empregadas na cela da delegacia Fonte: <http://gshow.globo.com/novelas/cheias-de-charme/capitulo/2012/4/16/cida-rosario-epenha-fazem-um-pacto.html>

Penha se ajeita no banco: "É isso aí meninas. Tava ruim, sempre pode piorar.".

Rosário, que usa uniforme do Aperitivo Buffet onde trabalha com seu pai, se levanta: "Tava há um mês vivendo em função desse show." - a câmera desce e focaliza Rosário - "Sonhando em entregar esse material pro Fabian. Agora...”.

O som cessa.

Cida, que usa um vestido de festa, também se levanta: “Ó, Rosário. O que é teu tá guardado. Minha mãe sempre me dizia isso e eu sei que ela tava certa. Eu não vou passar a vida inteira lá na casa da dona Sônia, não. Eles são bons pra mim, mas alguma coisa me diz que eu tenho futuro.”.

Penha: “Aí, o meu futuro é negociar dívida de cartão, tá.”. 
Rosário e Cida se indignam com a fala da moça e sentam de volta no banco ao lado de Penha, que usa vestido jeans, jaqueta, brincos de argola grandes, pulseiras e uma faixa laranja na cabeça.

Cida: "Que que é isso?".

Rosário: "Não fala assim não que atrai.".

Penha: "Eu não tenho esperança, gente, largar essa vida de empreguete.".

Rosário: "Como é que é? Vida de que?".

Uma música levemente animada, sem letra, começa a tocar.

Penha faz uma expressão facial engraçada: "Empreguete.".

Risos

Rosário: "Eu gostei, empreguete.".

Rosário: "Bora fazer um pacto? - ela fala devagar para enfatizar as palavras - "Dia de empreguete, véspera de madame.”.

Cida: "Hum.".

Penha: "Pô, se dependesse da gente.".

Cida: "Ué, e vai depender de quem? De patroa é que não é.".

Rosário: “Ah não Penha, vai, vai. Vamos mudar esse jogo. Vai, muda esse astral. Tudo bem que hoje a realidade ganhou do sonho. Mas amanhã, com a ajuda das colega, quem sabe não é a Chayene que vai tá servindo cafezinho pra tu?".

Penha: "humm."

Cida: “Adorei. Eu topo. Eu topo fazer esse pacto. Que nem naquela história, lembra? Dos Três Mosqueteiros?".

Rosário: "Só que a gente, nós somos as três empreguetes. Vamos vai. Uma por todas e todas por uma.”. - Rosário se dirige a Penha - "Vem mulher, anima, vamos, vamos.".

Penha: “Ajuda nunca é demais né, vamos lá então.”.

Todas unem as mãos.

Penha: "Dia de empreguete.".

Todas falam alto: "Véspera de madame. Uuuuuul.".

E soltam as mãos. A câmera grava de um ângulo superior novamente.

Elas riem. Rosário dá pulinhos e bate palmas.

Penha: "E bem madame.".

A câmera volta para a altura dos olhos novamente.

Funcionário da penitenciária: "Delegado vai receber vocês agora.". 
O som para de tocar. As três aparecem na mesa do delegado.

Delegado: "Bom. Dona Maria da Penha, você pode ir pra casa. Sua queixa foi registrada. E você vai só aguardar a audiência de conciliação.”.

Maria da Penha: "Reconciliação com a Dona Chayene? É ruim hein.”.

Delegado: "Dona Maria do Rosário vai só levar uma advertência, porque trabalhadora, carteira assinada, né? E pra sua sorte a produção do show telefonou e retirou a queixa, então...”.

Um som curto que parece de xilofone é soado para demarcar a surpresa de Rosário.

Maria do Rosário: "Será que foi um pedido do próprio Fabian?".

Uma música animada começa a tocar, sem letra.

Delegado: "Bom, quanto à senhorita, Maria Aparecida, o seu lugar é na escola, né, não na balada. Então, a senhorita fica esperta e se liga né, por favor.”.

Cida: "Pode deixar seu delegado, inclusive eu sou ótima aluna, viu.".

Delegado: “Aham. Bom, podem ir tá. Meu tempo é caro, eu não quero ficar gastando dinheiro do estado segurando trabalhador, né.”.

Agradecimentos.

Delegado: "Vamos lá. Tá ótimo.".

Foco no rosto do delegado: "Bando de malucas.".

Do lado de fora da delegacia. A música para de tocar. Elas passam em frente a uma barraca de cachorro-quente que está cheia. É noite.

Penha: "Bom, a gente já trocou telefone, né.".

Rosário: "Então, vamos se adicionar e não vamos se perder, hein.".

Cida: “Ó, e depois de amanhã é o meu aniversário. Me liguem, hein.”.

Penha: "Gente, eu vou ter que ir embora, que eu tenho filho pequeno, deve tá todo mundo preocupado lá em casa comigo.”.

Elas se despedem com beijo no rosto. Começa a tocar uma música, sem letra, com violão.

Penha (para Rosário): “Tu não ta indo pro Borralho?”.

Rosário: "Tô.".

Penha: "Vamos junta. Tchau, Cida.". 


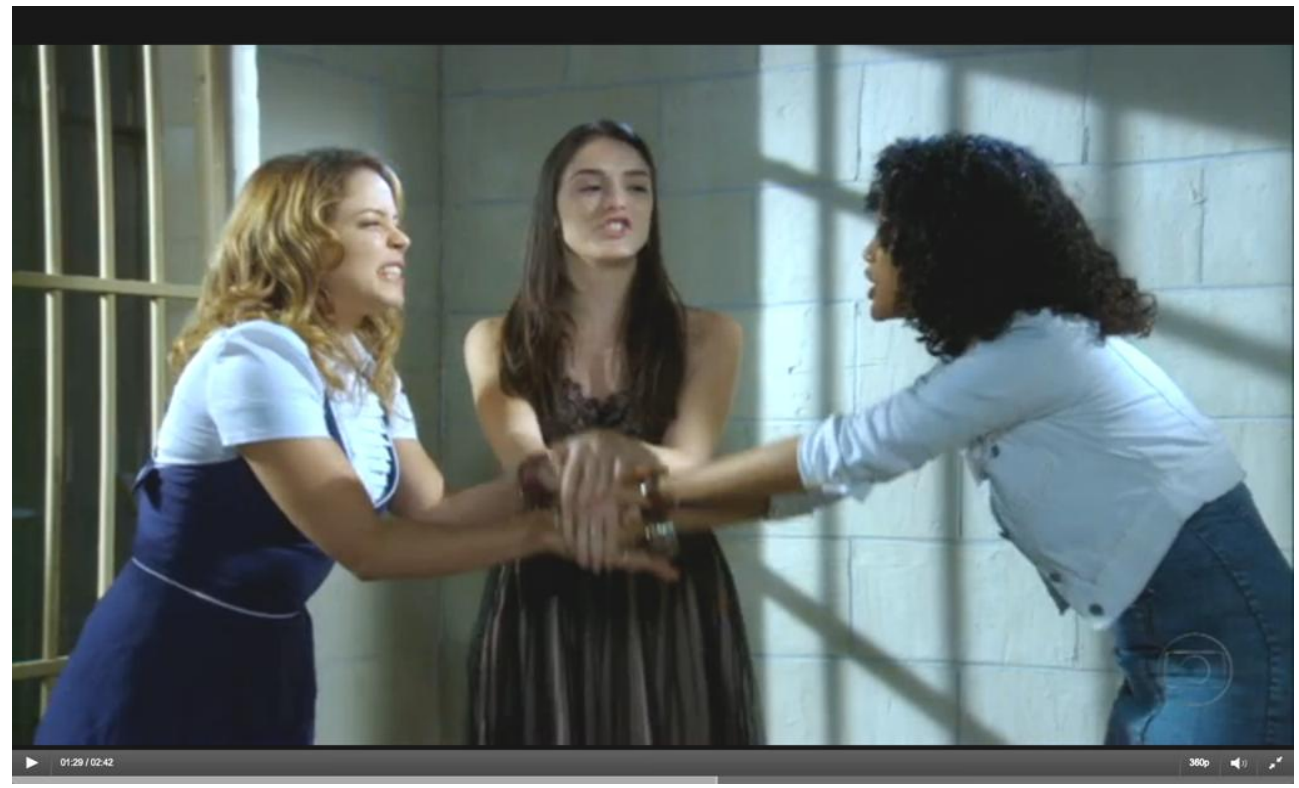

Figura 9 - As empreguetes fazem um pacto

Fonte: <http://gshow.globo.com/novelas/cheias-de-charme/capitulo/2012/4/16/cida-rosario-epenha-fazem-um-pacto.html $>$

Na significação acional dessa cena temos a simulação de um gênero primário de conversa informal em uma cela de prisão entre as três empregadas que se conheceram há poucos instantes. A conversa não é tão informal quanto as que são desenvolvidas nas cenas analisadas de Avenida Brasil.

De acordo com o teórico Bakhtin (2003), a diversidade dos gêneros do discurso é muito grande, sobretudo dos gêneros primários, que contempla, por exemplo, as breves saudações, despedida, felicitações, votos, informações sobre a saúde, dentre outras. Há formas oficiais e respeitosas e também há formas familiares em diferentes graus, assim como formas íntimas. "A diversidade desses gêneros é determinada pelo fato de que eles são diferentes em função da situação, da posição social e das relações pessoais de reciprocidade entre os participantes da comunicação [...]”. (BAKHTIN, 2003, p. 283).

Apesar das graduações de familiaridade e da existência de gêneros mais formais, Bakhtin (2003) que eles podem se misturar, como, por exemplo, transferir a forma de gênero da saudação do campo oficial para o campo da comunicação familiar com uma reacentuação irônico-paródica. 


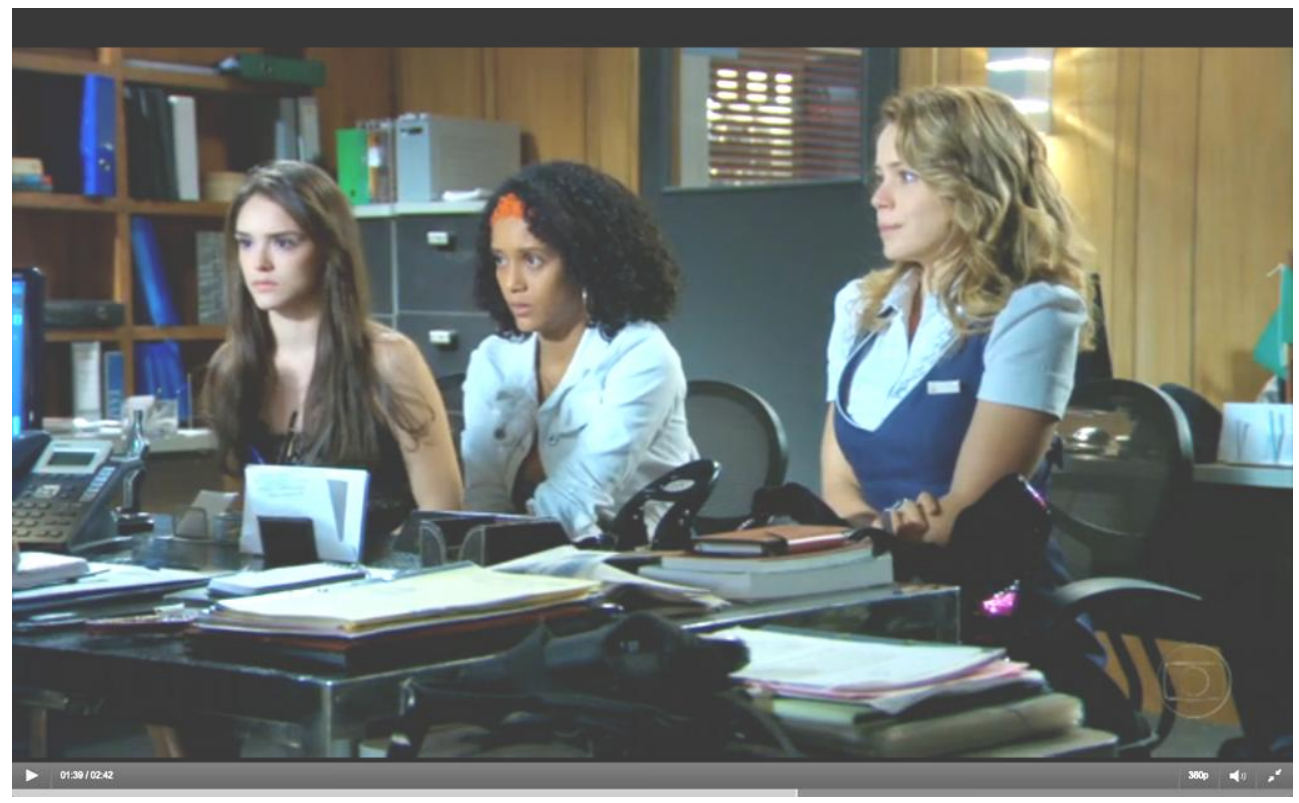

Figura 10 - Imagem das três empregadas na sala do delegado

Fonte: <http://gshow.globo.com/novelas/cheias-de-charme/capitulo/2012/4/16/cida-rosarioe-penha-fazem-um-pacto.html>

Na cena destacada temos a simulação de conversa informal entre as três moças que se identificaram pela profissão de doméstica e se encontram, assim, na mesma situação social. Posteriormente, temos a conversa das três com o delegado. Pressupõe-se que o diálogo seja mais formal e, justamente por isso, chama a atenção o vocabulário empregado pelo delegado quando se dirige a Maria Aparecida: "fica esperta e se liga". Parece uma tentativa de se aproximar do universo jovem da moça, já que ele está justamente dizendo que o seu lugar é na escola. O bem educacional é visto, assim, como possibilidade de mudança e ascensão social.

De maneira geral, as falas na cena são coloquiais. Como: "É isso aí meninas”, "Pô", "Bora", "É ruim, hein". Também há problemas de concordância: "com a ajuda das colega", "vamos junta".

Ainda há a introdução de um novo termo por Penha, "empreguete" para designar empregada doméstica. Nasce nessa cena a expressão que irá acompanhar as personagens durante toda a trama e terá adesão também dos outros personagens.

As músicas ajudam o telespectador a entrar no clima das cenas. No começo, a canção escolhida possui uma entonação condizente com a situação embaraçosa na qual o trio se encontra. Conforme o ânimo aumenta, músicas mais alegres são selecionadas. Assim como o som de xilofone utilizado para marcar a surpresa de Maria do Rosário, 
quando ela descobre que a queixa fora retirada e, assim, começa a imaginar que tenha sido um pedido de seu ídolo Fabian.

As falas e as vestimentas das personagens colocam Penha em oposição a Maria Aparecida e Maria do Rosário. Penha é a única negra das três e, além de suas roupas e gestualidade indicarem maior simplicidade, ela se mostra a mais desanimada e pessimista do trio quando diz que o que está ruim sempre pode piorar, que seu futuro é negociar dívida de cartão, que ela não tem esperança de largar a vida de "empreguete". Suas falas trazem a temática do acesso ao crédito e o problema do endividamento pela lógica do aumento do poder de consumo da classe trabalhadora.

Rosário e Cia repreendem Penha e tentam animá-la. Quando Rosário sugere o pacto "dia de empreguete, véspera de madame", Penha diz "Pô, se dependesse da gente", no caso se dependesse delas empregadas se tornarem madames. Cida, então, pergunta de quem dependeria e diz que de patroa não é. O discurso da Cida revela que deixar de ser empregada doméstica é um esforço individual. Ao contrário, o conformismo de Penha nos remete ao fato de que existe algo maior, além das forças individuais, por trás das diferenças sociais, pois não depende apenas "da gente", empregadas domésticas, mudar de vida radicalmente. Quando Maria da Penha diz "Pô, se dependesse da gente" de modo sonhador, sorrindo e olhando para o alto, ela não expõe de quem dependeria então, na opinião dela.

Na fala "Ué, e vai depender de quem? De patroa é que não é" Cida coloca no centro da questão a oposição entre patroas e empregadas, ou seja, as relações pessoais, ignorando as diferenças sociais de modo amplo, que ultrapassam os problemas individuais. Então, o discurso de Maria Aparecida se relaciona, de certa forma, com o discurso neoliberal, economicista, que frisa o individualismo e ignora as diferenças estruturais (SOUZA, 2012).

Mais adiante, Rosário propõe mudar o jogo, "com a ajuda das colega" e sugere para Penha que quem sabe no futuro Chayene (patroa de Penha na ocasião) não estará servindo café para ela. O pacto "dia de empreguete, véspera de madame" propõe uma inversão de papéis. A madame na visão das personagens é aquela mulher com dinheiro que conta com uma empregada doméstica, o que revela que o desejo das "empreguetes" é estar no lugar de suas patroas, perpetuando o mesmo ciclo.

Cida gosta da ideia e compara o pacto com a história dos Três Mosqueteiros. Ela se demonstra a mais romântica das três. Aqui temos um caso de intertextualidade 
alusiva, nos termos explicados por Fiorin (2012) e já explicados nesta dissertação, pois a obra Os Três Mosqueteiros existe enquanto uma unidade textual, como folhetim, romance ou até mesmo a adaptação em filme.

O romance histórico de Alexandre Dumas, publicado originalmente em folhetim no século XIX, conta a aventura de quatro jovens que lutam a favor da Coroa francesa no século XVII. "Um por todos e todos por um” era o lema dos "Três Mosqueteiros". Na cena de Cheias de Charme, há a comparação entre Os Três Mosqueteiros e as três Empreguetes em decorrência do pacto e da cumplicidade entre os mosqueteiros.

Depois, no momento em que o delegado chama as três para conversar e elas são liberadas, o homem diz "Meu tempo é caro, eu não quero ficar gastando dinheiro do estado segurando trabalhador né". A frase soa como uma "desculpa" pela prisão das três moças, que são qualificadas como trabalhadoras. Há uma amenização, assim, da hostilidade inicial da "justiça" representada pelo delegado para com as trabalhadoras.

No final, elas saem da delegacia conversando, demonstrando terem se tornado muito amigas. Cida quer que elas se lembrem de seu aniversário. Rosário reforça para que elas não se percam e se "adicionem" (nesse caso parece uma referência a alguma rede social da internet ou adicionar os contados de telefone. Não fica claro). Penha sugere a Rosário irem juntas porque ambas moram na comunidade Borralho.

É importante ressaltar que nessa cena Maria da Penha traz mais à tona o conflito de classes propriamente dito. Além dos aspectos já comentados, Maria Aparecida e Maria do Rosário estão na delegacia, respectivamente, por uma briga em casa noturna e confusão no show de Fabian. Maria da Penha, por sua vez, foi prestar queixa contra a patroa que a agredira.

Quanto ao gênero, apesar de ser constituída por simulações de gêneros primários inseridos no gênero secundário da telenovela, a cena destacada tem um vínculo maior com o gênero da trama como um todo, ao trazer mais referências à narrativa e ser uma demonstração do tom provador-pacificador (MARTÍN-BARBERO, 2009) peculiar ao folhetim e presente na telenovela.

As três empregadas estão presas, em uma situação ruim, vivenciando o descrédito das autoridades, há o desânimo de Maria da Penha e a dura realidade trazida por ela, mas, no fim da cena tudo fica bem. Elas fazem o pacto em um clima de esperança para “mudar esse jogo" e são soltas. A seleção musical reforça o estado de ânimo. As três saem felizes, agradecem o delegado e ainda tornaram-se amigas. 
Desse modo, na significação identificacional é possível delinear o ethos romântico, trazido por Cida, pela ideia do pacto, pela esperança em mudar de situação e promessa de uma nova etapa; o ethos da dificuldade social, presente na cela e no discurso de Penha; e o ethos individualista, que é forte no discurso de Penha e Rosário que ressaltam as relações pessoais e a vontade própria como definidoras de boas chances e ignoram os problemas econômicos de forma ampla.

Assim, na significação representacional temos um discurso que traz de forma romântica a possibilidade de superação das dificuldades sociais por meio da vontade individual. O discurso de Penha acaba por não ser sustentado durante toda a cena, pois ela se rende ao pacto, porque "ajuda nunca é demais". O discurso nos remete ao economicismo dominante discutido por Jessé Souza (2012) e ao personalismo no modo de tratar as diferenças elucidado por Ronsini (2012).

Quando é transmitida a cena "Penha vibra com a casa reformada", as Empreguetes haviam acabado de chegar de uma turnê. Enquanto elas estiveram fora, a casa de Penha fora reformada e aumentada. Sua amiga Ivone foi a responsável pela obra. Novos equipamentos domésticos foram comprados também. Penha retorna e está tudo pronto. A cena tem início com Patrick recepcionando a mãe, do lado de fora da casa. É um dia ensolarado.

Patrick: "Mãe, fecha o olho.”.

Penha: "Pronto, fechei.".

Patrick: "Sem olhar.".

Penha: “Tá bom.”.

Começa a tocar o samba chamado "Tudo Nosso" da banda Samba Livre.

Penha: "Posso abrir?".

Patrick: "Agora, pode olhar. Pode olhar.".

Penha suspira e se surpreende, a casa do lado de fora está pintada de cor salmão. Em frente, há a quadra da comunidade reformada também: "Meu pai do céu! E a quadra, Patrick? Toda toda pintadinha, novinha, pá tu brincar, meu filho! Eu vou fazer muito pagode nessa quadra, meu bem. Vou fazer é muito do churrasco...” - ela balança o corpo - "Eu quero ver minha laje ... a laje tá linda?".

Patrick: "A senhora vai adorar.".

Penha se empolga: "Vou adorar?". 
Patrick: "Vai".

Penha grita: "Vou lá. Cadê minha laaje?".

A câmera faz um plano aberto da casa e mostra Penha subindo uma escada externa para a laje. Ela veste calça jeans com brilho, cinto bem largo, salto alto, blusa clara brilhante, justa, em tons rosados.

Penha: “aiii..quero ver!”. Gritinhos.

Penha: "Não tô acreditando. Geennte é mada demais.".

A laje está decorada com espreguiçadeiras, cadeiras, guarda-sol, plantas, postes de iluminação, entre outros utensílios.

Penha deita em uma espreguiçadeira: "Vou ficar assim... pegando Sol... não tô acreditando..tô tomando Sol. Maravi...Deus do céu...caraca, aí...” - ela se levanta, coloca as mãos para o alto e sacode o corpo - "Cobertura de madame! Uuul." - ela se dirige para o parapeito e grita para as pessoas que jogam bola na quadra - "Gostaram da quadra?" - as pessoas gritam - "Gostaram da quadra?"- ela joga beijo para o alto "Amo vocêeees!" - o pessoal se anima e joga beijo de volta - "Uuuuuull".

Em seguida, Penha já aparece dentro da casa, que está cheia de convidados. Ela toca a nova televisão grande e cai no sofá. A música cessa.

Já levantada, Penha fala sobre um aparador azul atrás do sofá: "Não, isso é muito lindo. Isso, quando Ivone me mandou a foto eu já fiquei louca.”.

$\mathrm{Na}$ mesa de jantar outras crianças estão sentadas com Patrick, há suco e mexericas descascadas na mesa.

Penha: “Ai, Ivone. Minha casa tá...nossa tá uma beleza, meu Deus do céu. E como é que tu é caprichosa, menina. Nem parece que tava em obra isso aqui."

Ivone suspira.

Penha se dirige aos homens que fizeram o serviço de pedreiro, eles estão atrás do balcão da cozinha comendo fruta - "Não, e a peãozada, pô, cês arrebentaram, cara. ela cumprimenta todos com um toque na mão de cada um, com os punhos fechados “Tudo de parabéns. Tudo de parabéns.”.

Penha olha para Sandro: "Tu eu sei que a única coisa que tu fez nessa obra foi o teste drive do sofá mesmo né.”.

Os homens da obra dão risada.

Ivone alerta Penha, que entra na área de serviço: "Tá falando só os detalhezinhos de acabamento aí.". 
Penha: "Não, tô vendo, tô vendo que tem uma pintura que tá aqui que tá escorrendo né.".

Ruço (Nado Grimberg) se explica a Penha: "Não, Dona Penha, a gente vai dar outra demão, não é?” - Seus colegas confirmam.

Sandro fala com Penha: "Aí, se tivesse me colocado pá olhar a obra ia tá tudo nos trinque, mas foi deixar na mão da Ivone, neguinha...”.

Penha o ignora.

Ivone: Olha o fugão. Olha o fugão de cinco bocas, Penha!

Foco no fogão que é da marca Esmaltec.

Penha: De cinco boca, Ivone. Quando eu pensei que ia ter um fugão de cinco boca na minha casa, gente.

Ivone: E a geladeira? A geladeira! É duplex, Penha. Tudo da linha que você sempre gostou.

Penha: Pô, claro! Eu ia mudar agora?

É possível ler a marca Esmaltec na geladeira, que já está com alguns imãs.

Ivone: "sabia que cê ia gostar.".

Patrick: "Mãe! Cê tem que ver a hidro.".

Penha: "Tem uma hidrooo?".

Ivone ri.

Patrick: "Tem.”.

Penha: "Geeente, mas eu tô demais, eu tô muito chique de fina. Tô chocada.”.

Ivone: "Ai, sabia que cê ia gostar.".

Penha: "Menina, meu Deus do céu!" - Ela encosta-se à máquina de lavar roupa.

Sandro se aproxima, e começa a tocar o samba tema do personagem, "Se Vira" de Beth Carvalho.

Penha: "Ai, eu tô assim... sei lá que eu tô sonhando, sabe. Minha casa toda bonitona. Máquina de lavar roupa, fugão, geladeira, tudo zero bala...não tô nem acreditando nisso.".

Sandro fala para a esposa com doçura: "Pô, a gente conseguiu, né, neguinha.".

Penha: "Que mané a gente conseguiu Sandro. Que gente que conseguiu? Eu consegui, meu filho." - Ela sai com a cabeça erguida, enquanto Sandro fica com um ar desapontado. 
Alana: "Aí, minha irmã, ficou lindona nossa casa, né. Eu ainda acho que tu devia ter comprado apartamento no condomínio da Barra, mas...”.

Penha: "Tá doida menina, que eu não me mudo pá condomínio de madame metida a besta nem morta. Tu sabe por que? Porque não tem lugar mais animado no mundo, meu amor, que o meu Borralho.".

A música para de tocar. As outras Empreguetes estão presentes.

Cida conversa com Heraldo (Sergio Menezes): "Eu morei a vida inteira lá no Casa Grande, mas é muita frescura, uma falsidade danada".

Rosário, que veste um colete que parece de pele: "Tu não morou no Casa Grande né, cê trabalhava lá, é bem diferente, a casa não era sua." - Heraldo concorda.

Cida usa uma blusa rosa com brilho: "Bom, nesse momento, eu acho o Borralho mais a minha cara".

Rosário: "Ah, pois eu já falei com o corretor. Amanhã mesmo ele vai mostrar uns apaartamentos pra gente, papito". Ela se dirige a seu pai.

Pai de Rosário, Sydnei, (Daniel Dantas): "Não, pra mim vai ser muito difícil deixar o nosso cantinho. Tem tantas lembranças dali, fui tão feliz com o Anderson lá.".

Rosário: "Mas você também vai ser muito feliz no nosso novo cantinho de luxo".

Anderson: "É seu Sydnei, às vezes vai ser bom mudar de ares. E depois a Rosário já sabe como vai ser o quarto dela de estrela desde os 10 anos.".

Rosário: "Aham".

Risos.

Cida: "Só a Rosário...Ah gente, se vocês forem vender o apartamento, eu fíco interessada em comprar pra madrinha, viu."

Madrinha da Cida, Valda (Dhu Moraes), pergunta rindo: "Por acaso, eu ouvi meu nome?".

Na significação acional dessa cena, há simulação de diálogos informais, por isso acredita-se que ela seja composta pela representação de gêneros primários. Primeiro, há a conversa de Penha com o seu filho, que, apesar da informalidade, trata-a por senhora e a ajuda segurando sua bolsa enquanto ela vai conhecer a laje.

Na parte de cima, a personagem fala sozinha deslumbrada com a reforma. Já do lado de dentro, a casa está cheia de pessoas que parecem vizinhos, como Ivone. Também estão presentes, além dos moradores da casa, com exceção de Elano, os 
pedreiros que participaram da obra, colegas de Patrick, Maria do Rosário e seu pai, Maria Aparecida e sua madrinha, o empresário das Empreguetes, de Fabian e de Chayene, Tom Bastos (Bruno Mazeo), entre outros personagens e figurantes.

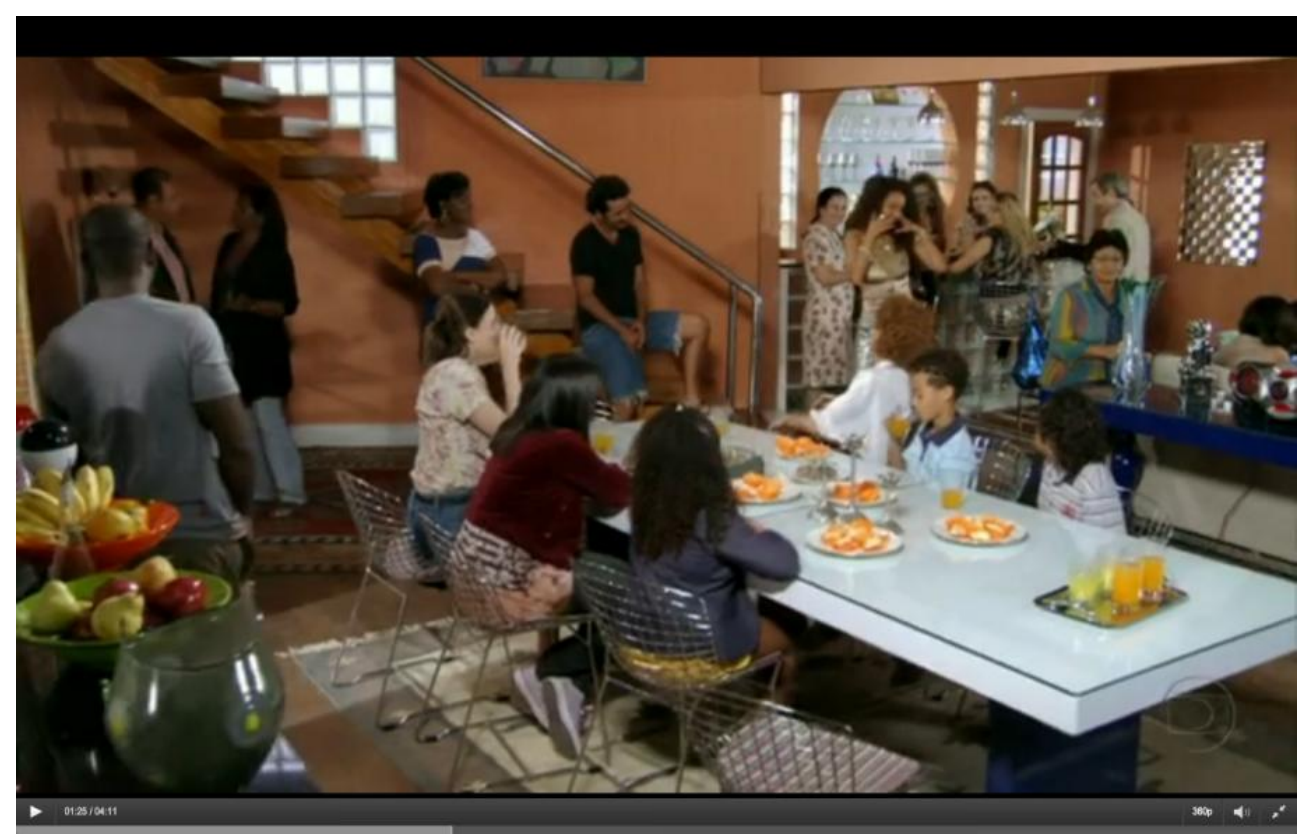

Figura 11 - Penha recebe convidados para celebrar a casa reformada Fonte: <http://gshow.globo.com/novelas/cheias-de-charme/capitulo/2012/7/14/fabianaparece-no- orfanato-e-surpreende-rosario.html>

Trata-se de uma reunião informal, em plena luz do dia, mas indica que a reforma da casa é um grande acontecimento que coincidiu com o retorno das Empreguetes da turnê. Penha está contente com a casa, parabeniza Ivone e os pedreiros (que a tratam por Dona Penha), mas repreende Sandro, porque ela o conhece e sabe que ele não ajudou e, ainda assim, finge ser parte dessa conquista.

Sandro é a representação estereotipada do malandro carioca. Sua vestimenta, seu modo de falar e suas atitudes são indicativos disso. A descrição de Sandro no site oficial da trama também aponta para tal fato: "Malandro, adora ficar na frente da televisão o dia todo, com uma cervejinha, mandando os outros fazerem as coisas para ele, reclamando de tudo". ${ }^{20}$

As músicas na cena marcam os sentimentos dos personagens e também fazem parte de sua caracterização. No começo, o samba condiz com a alegria de Maria da Penha e o ambiente popular, reforçado pelas pessoas simples passando na rua. Quando

\footnotetext{
20 Disponível em: <http://gshow.globo.com/novelas/cheias-de-charme/personagem/sandrobarbosa.html\#perfil>. Acesso em abril de 2014.
} 
Sandro se aproxima da esposa, por exemplo, a sua música tema começa a tocar, que é uma marca do personagem.

Nesse momento, em que Sandro está por perto, a moça pensa estar sonhando de tanta felicidade. Sandro aproveita a situação e afirma "Pô, a gente conseguiu, né, neguinha.". Penha rebate afirmando, com orgulho, que foi ela que conseguiu. Há um tom cômico em Sandro e uma indicação na fala de Penha de que a melhora na casa foi possível graças ao seu esforço, porque Sandro nunca ajudou.

Penha usa linguagem coloquial, informal e, em alguns momentos, apresenta problemas de português, como erros de concordância. Por exemplo: "peãozada", "fugão de cinco boca", "caraca", "pá”, “chique de fina”, "zero bala”. Ela é escandalosa e grita de alegria para ver a laje e também com as pessoas da quadra: "Cadê minha laaje", "Uuul" "Amo vocêeeeess".

Penha também utiliza a palavra "mada" para indicar que a laje está parecendo de "madame" e se imagina tomando sol. Depois ela frisa "cobertura de madame". Sua postura é descontraída e solta, ela balança o corpo, por exemplo, quando está empolgada, e se joga no sofá bem relaxada quando entra na casa.

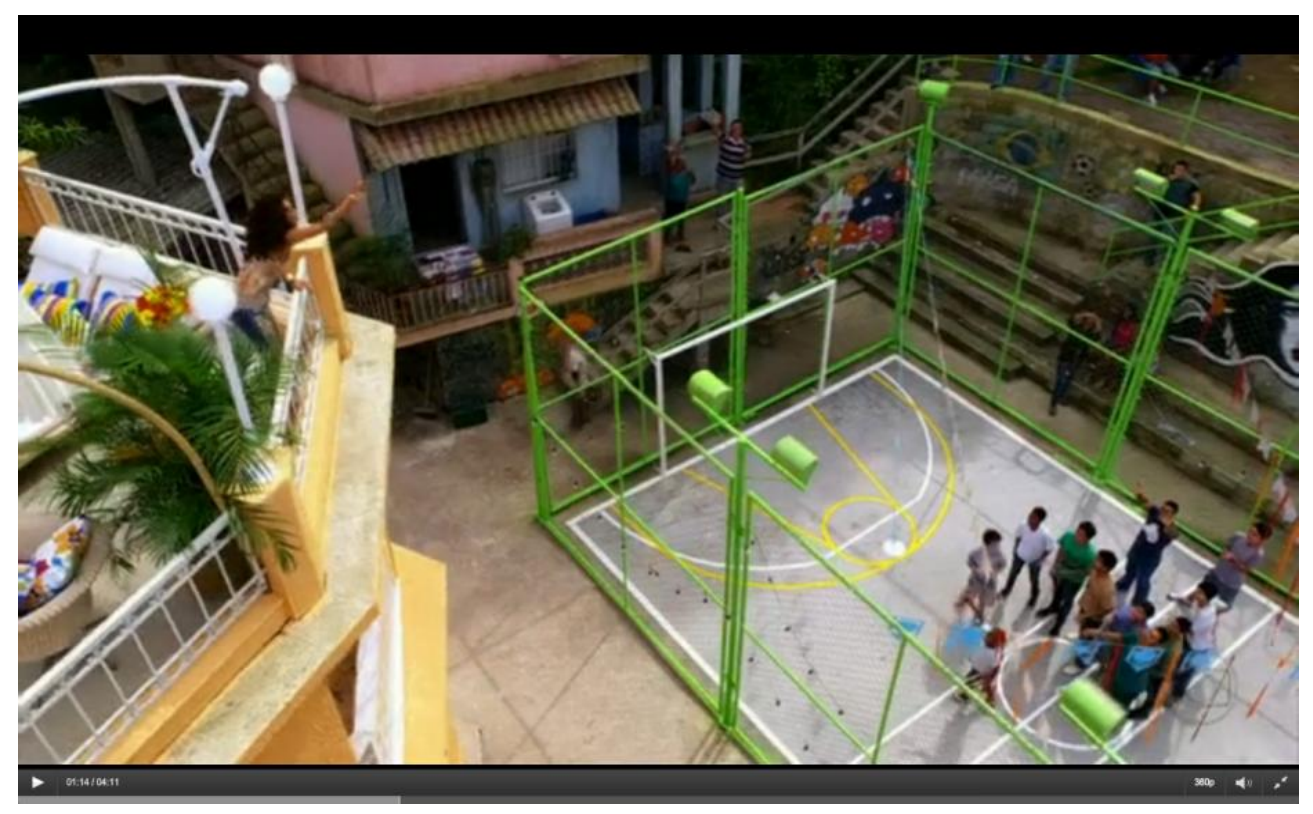

Figura 12 - Penha acena da sua laje para os moradores do Borralho

Fonte: <http://gshow.globo.com/novelas/cheias-de-charme/capitulo/2012/7/14/fabian-apareceno-orfanato-e-surpreende-rosario.html >

Quando Penha sobe para a laje é possível visualizar que a casa teve um crescimento vertical, ela aparenta ter três andares e uma disposição no formato da letra 
"L". A escada que a personagem sobe, por exemplo, passa por cima da residência, bastante simples, de outra pessoa. Na laje, além dos objetos decorativos já explanados, há uma churrasqueira e uma porta pequena que parece ser de um banheiro, em cima desse pequeno ambiente há uma caixa d'água.

A reforma na quadra que é do Borralho, na qual o filho de Penha brinca, revela o espírito de comunidade da personagem, quase como se a quadra fizesse parte da sua casa e as pessoas do bairro fossem sua família também. Os moradores acenam e mandam beijo para ela. Penha demonstra um gosto popular também quando diz para o filho que vai fazer muito pagode e churrasco na quadra.

Em relação à primeira cena analisada, Penha está um pouco diferente. Ela fez luzes nos cabelos, que parecem mais bem cuidados. A roupa parece mais sofisticada, ela usa mais brilho, mas o estilo continua o mesmo. São vestimentas justas, pulseiras e sandálias com um salto bem alto.

Quando Penha entra na casa e toca a televisão, é possível visualizar um objeto decorativo na parede acima do aparelho. O aparador azul, que é elogiado por Penha, abriga alguns objetos decorativos e também um rádio com detalhes vermelhos que, em um primeiro olhar, parece não combinar com o restante. A casa está maior e mais sofisticada que anteriormente, mas continua simples.

Além da reforma, a casa foi equipada com novos utensílios, como fogão de cinco bocas, geladeira duplex, máquina de lavar roupa. Esse consumo indica que a personagem não dispunha antes de dinheiro para consumir equipamentos básicos para a casa.

A celebração do ritual de conquista da moradia se soma ao ritual de posse de eletrodomésticos, bens de decoração e roupas que sinalizam o aumento do poder de consumo e a ascensão social. A cena representa o que o antropólogo Grant McCracken (2003) aborda a respeito do ritual de posse, que engloba atividades realizadas pelos consumidores, como limpar e discutir sobre seus bens, assim como celebrar a abertura de uma casa, por exemplo. Essas atividades parecem ter o efeito adicional, segundo o autor, de permitir ao consumidor reivindicar o que é seu e assumir um tipo de posse sobre o significado de seus bens de consumo.

Como vimos, as agências de publicidade e o mundo da moda transportam este significado do mundo cultural e historicamente constituído para os bens. Através de seus rituais de posse, os 
indivíduos transferem este significado dos bens para suas vidas. (MCCRACKEN, 2003, p. 116). ${ }^{21}$

Além dos equipamentos que podem ser considerados básicos, Maria da Penha ainda ganhou uma banheira de hidromassagem e uma televisão maior. Quando Ivone apresenta o fogão e a geladeira, há merchandising da marca Esmaltec, que já era utilizada pela personagem. "Pô, claro! Eu ia mudar agora?" Penha declara para Ivone.

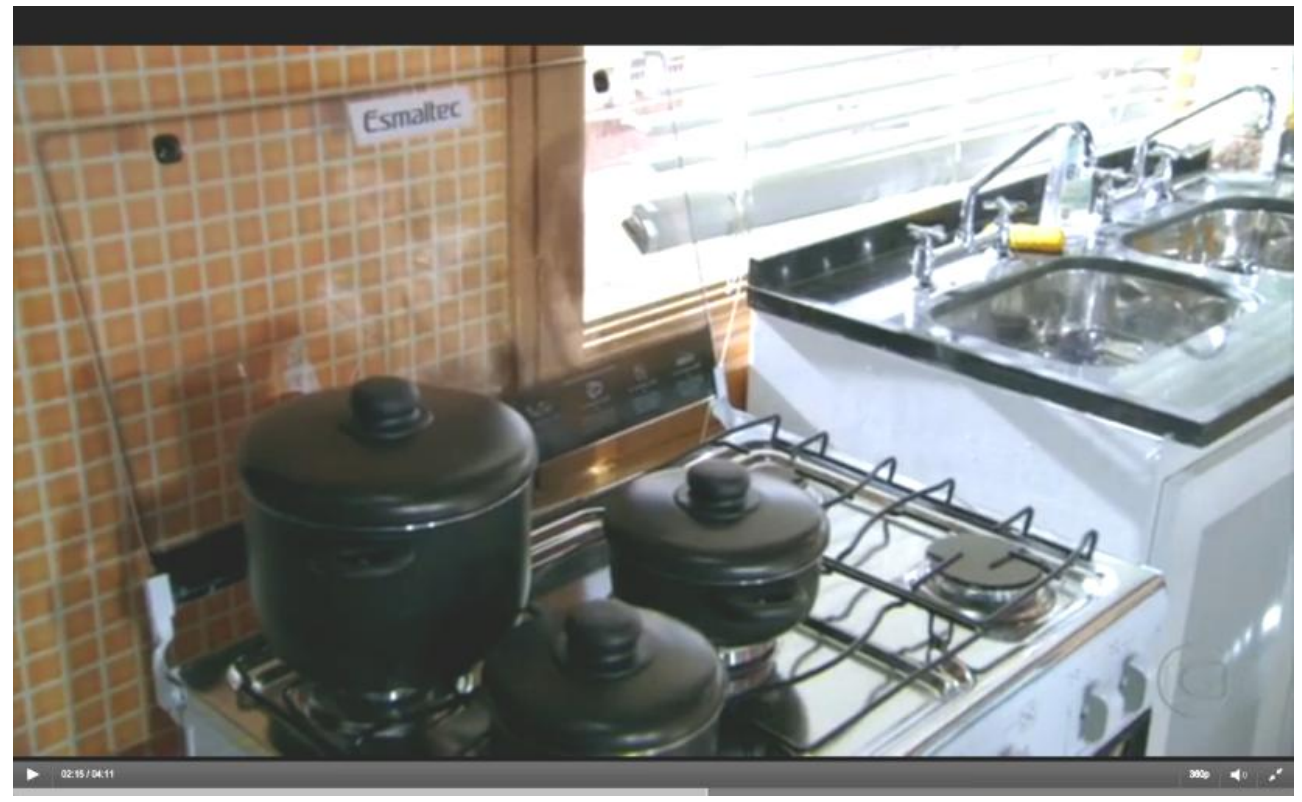

Figura 13 - Merchandising da marca Esmaltec

Fonte: <http://gshow.globo.com/novelas/cheias-de-charme/capitulo/2012/7/14/fabianaparece-no-orfanato-e-surpreende-rosario.html>

A personagem também apresenta a mesma resistência para mudança quando sua irmã opina que ela poderia ter comprado um apartamento na Barra, em referência ao bairro nobre carioca Barra da Tijuca. Penha não gosta da ideia, porque não quer se mudar "pá condomínio de madame metida a besta nem morta" porque para ela não há lugar mais animado que o Borralho.

Ao contrário dela, Maria do Rosário, que também mora no Borralho, mas não aparece nas cenas integrada ao bairro como Penha, já está procurando apartamento em outro lugar, "um cantinho de luxo". Seu pai não se sente empolgado pela ideia: "Não, pra mim vai ser muito difícil deixar o nosso cantinho. Tem tantas lembranças dali, fui tão feliz com o Anderson lá.”.

\footnotetext{
${ }^{21}$ De acordo com McCracken (2003), o significado do mundo culturalmente constituído é transportado para os bens mediante o sistema publicitário e da moda. Os indivíduos, por sua vez, transferem o significado dos bens para suas vidas, pelos rituais de posse e também pelos rituais de troca, arrumação e despojamento.
} 
Cida, por sua vez, afirma que o Borralho tem mais a ver com ela no momento, pois ela está morando temporariamente com Penha. A moça expõe que no condomínio Casa Grande onde morou na condição de empregada há muita frescura e falsidade. Logo, deduz-se que o Borralho é o contrário, um lugar simples, habitado por pessoas sinceras.

Porém, esse argumento é desfeito por Rosário que enfatiza o fato de a colega ter trabalhado no Casa Grande, a casa não era dela, o que é bem diferente. Apesar da personagem não dar maiores explicações, subentende-se que a impressão que Cida tem do condomínio luxuoso perpassa pelo fato de ter sido empregada lá e não moradora.

De qualquer forma, no decorrer da trama Cida retorna para o condomínio Casa Grande quando descobre que seu ex-patrão Ernani Sarmento pode ser seu pai. De um modo geral, então, Penha é a única que tem uma relação forte com o seu bairro. E nessa cena, especificamente, o destaque é dado a Penha, à reforma da sua casa, ao seu sentimento em relação ao bairro e a alegria do Borralho.

Assim, na significação identificacional, há um ethos popular, perceptível nas vestimentas, nas falas, no comportamento de Penha e dos outros personagens, bem como no ambiente da casa, o bairro, a simplicidade, o deslumbramento com "luxos" nunca antes possíveis para a personagem. Os eletrodomésticos adquiridos revelam também que as condições anteriores eram bem pouco favoráveis, pois não permitiam a aquisição (ou renovação) de bens essenciais para a manutenção de uma casa. Trata-se de outro indício do ambiente popular.

Existe um tom comunitário, evocado pela quadra, pelas pessoas cumprimentando Penha, pelos convidados dentro da casa da moça, presente também quando a personagem afirma não querer deixar o bairro, ela utiliza até um pronome possessivo "meu" para falar do local: "Porque não tem lugar mais animado no mundo, meu amor, que o meu Borralho".

Nesse tom comunitário está implícita também a ideia de que na comunidade as pessoas são mais felizes, trazida pela fala de Penha e também de Cida, embora haja um contraponto por parte de Rosário. De qualquer modo, a alegria do ambiente, o alto astral das pessoas na quadra, por exemplo, corroboram com a visão de que a comunidade é animada como afirma Penha.

Há uma expressão de pertencimento que também se apresenta no momento em que Penha se demonstra fiel à linha de eletrodomésticos que sempre gostou. Ela expõe 
que não há motivo para mudar de linha agora (subentende-se o "agora" como equivalente à nova realidade financeira da personagem).

Embora possamos argumentar que a fidelidade à marca seja de natureza diferente do sentimento comunitário com o bairro, há similaridades entre as duas exposições, que dizem respeito ao pertencimento, à manutenção das raízes, dos gostos e expressam o desejo de continuidade existencial. Consideramos, então, a existência de um ethos comunitário que engloba as características comunitárias de Penha e do Borralho, a alegria da região e a fidelidade às raízes nessa cena.

Ademais, é perceptível que Penha possui o respeito do filho que a trata como "senhora", dos pedreiros que a chamam por "Dona", e também de Ivone que, além disso, demonstra carinho pela amiga. Esse respeito está relacionado ao seu caráter e ao trabalho que também é evocado na cena.

Penha, por exemplo, elogia o trabalho dos pedreiros da obra - o termo "peãozada" reforça a conotação de trabalho pesado -, o capricho de Ivone e deduz que o marido deve ter feito apenas o test drive do sofá. Todos riem de Sandro. Ele não possui o mesmo respeito de Penha e dos outros que trabalharam direito.

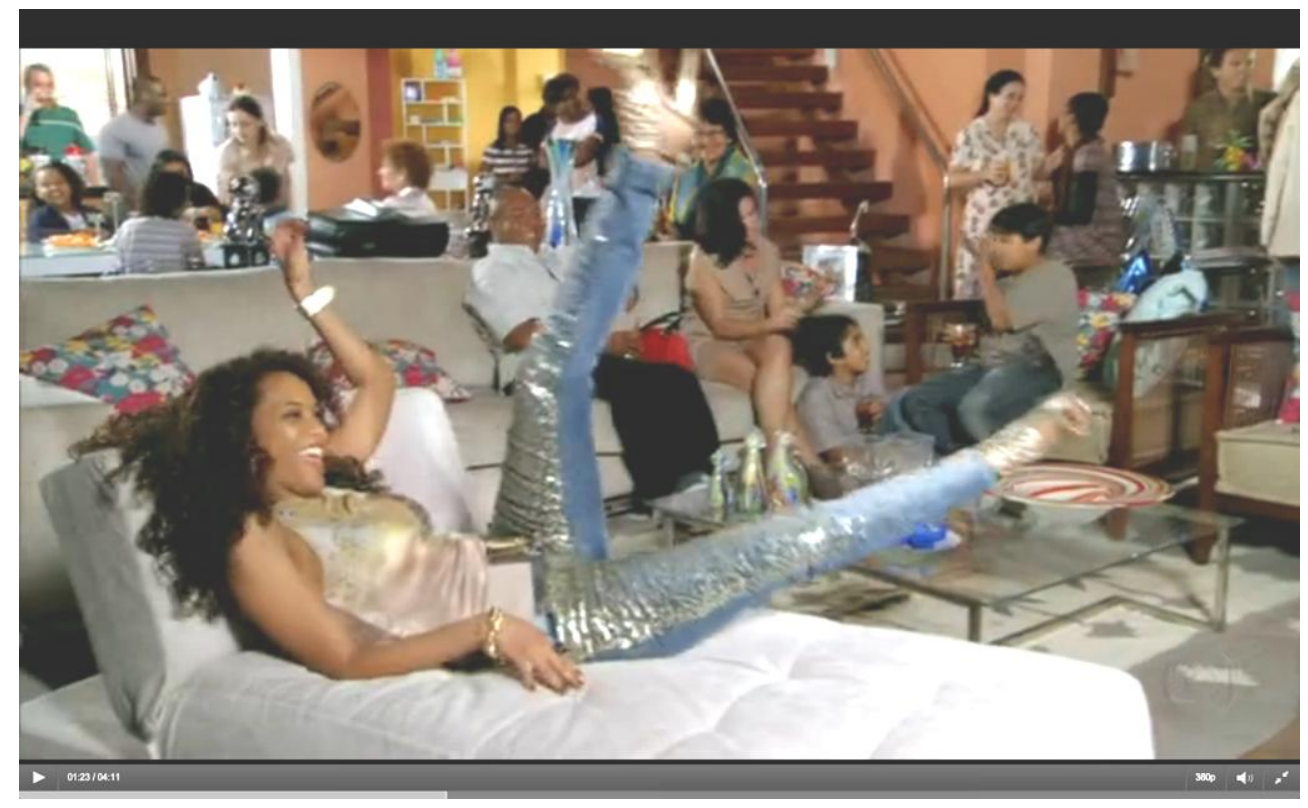

Figura 14 - Penha se joga no sofá, feliz com a casa reformada

Fonte: <http://gshow.globo.com/novelas/cheias-de-charme/capitulo/2012/7/14/fabianaparece-no-orfanato-e-surpreende-rosario.html>

Como é sabido pela prática discursiva levantada, Penha é mulher trabalhadora. Nessa cena, ela enfatiza que conseguiu a mudança na casa sozinha e não obteve a ajuda 
de Sandro: "Que mané a gente conseguiu Sandro. Que gente que conseguiu? Eu consegui, meu filho." É possível levantar assim o ethos da ética do trabalho, que, segundo Jessé Souza (2012) é uma característica da nova classe trabalhadora, os batalhadores.

Desse modo, os ethé popular, comunitário e do trabalho trazem na significação representacional um discurso popular que mostra a casa reformada de uma mulher trabalhadora que conseguiu melhorar de vida graças a seu esforço próprio, apesar das adversidades, como a malandragem de seu marido. Uma mulher que se mantêm fiel às suas raízes, que é popular e feliz em sua comunidade, um lugar simples, humilde, mas animado.

O esforço próprio de Penha nesse instante não conota a exaltação do individualismo e do mérito pessoal na sociedade capitalista como explicado em outros momentos. Nessa cena, Maria da Penha é representada como uma batalhadora, assim como Ivone e os pedreiros da casa.

É pertinente pontuar que, em uma entrevista ao jornal Folha de S. Paulo, Jessé Souza explica que sua crítica à ideia do mérito individual se refere a seu uso amesquinhado como ideologia, falsa percepção da realidade (MACHADO, 2011), que não leva em consideração as diferenças sociais. Isso não descarta a existência de esforço pessoal na nova classe trabalhadora. Inclusive, Souza (2012) demonstra em sua pesquisa que a nova classe trabalhadora é marcada por um grande esforço pessoal de trabalho, passado pela família, e pela capacidade de ultrapassar adversidades, assim como é percebido no discurso de Penha.

Além disso, a popularidade e o tom comunitário da cena condizem com o que Souza (2012) argumenta sobre o espírito comunitário e o capital cultural da nova classe trabalhadora.

Porém, a cena ainda reproduz o racismo de classe discutido por Souza (2012) por meio da figura do malandro Sandro. Além disso, há a transmissão da ideia de que os pobres sabem viver e são felizes, por meio das falas de Penha, por exemplo, que acredita que o Borralho é o lugar mais animado que conhece no mundo. Essa ideia pode ser considerada uma forma de reforçar a reprodução das diferenças sociais em tom humanizado, o que é peculiar ao gênero melodramático, na visão de Ronsini (2012).

Na cena "Sônia e Máslova ficam horrorizadas com as ironias de Penha", as Empreguetes fazem compras na loja Galerie, pertencente a Sônia, ex-patroa de Cida. A 
loja, que enfrenta problemas financeiros, está em liquidação. Trata-se de um ritual de compra.

No início, Sônia e Máslova (Aracy Balabanian) se incomodam com a presença das ex-empregadas, pois as duas personagens são preconceituosas e elitistas, assim como Isadora (Giselle Batista), filha de Sônia, que, além disso, tem ciúmes de Cida, pelo fato de seu marido Conrado (Jonatas Faro), neto de Máslova, já ter sido namorado da empreguete.

Porém, como Cida, Penha e Rosário estão salvando as vendas da loja, as madames concordam em atendê-las. Na cena escolhida, as personagens já fazem compras, junto de Socorro, que se autointitula personal colega das Empreguetes.

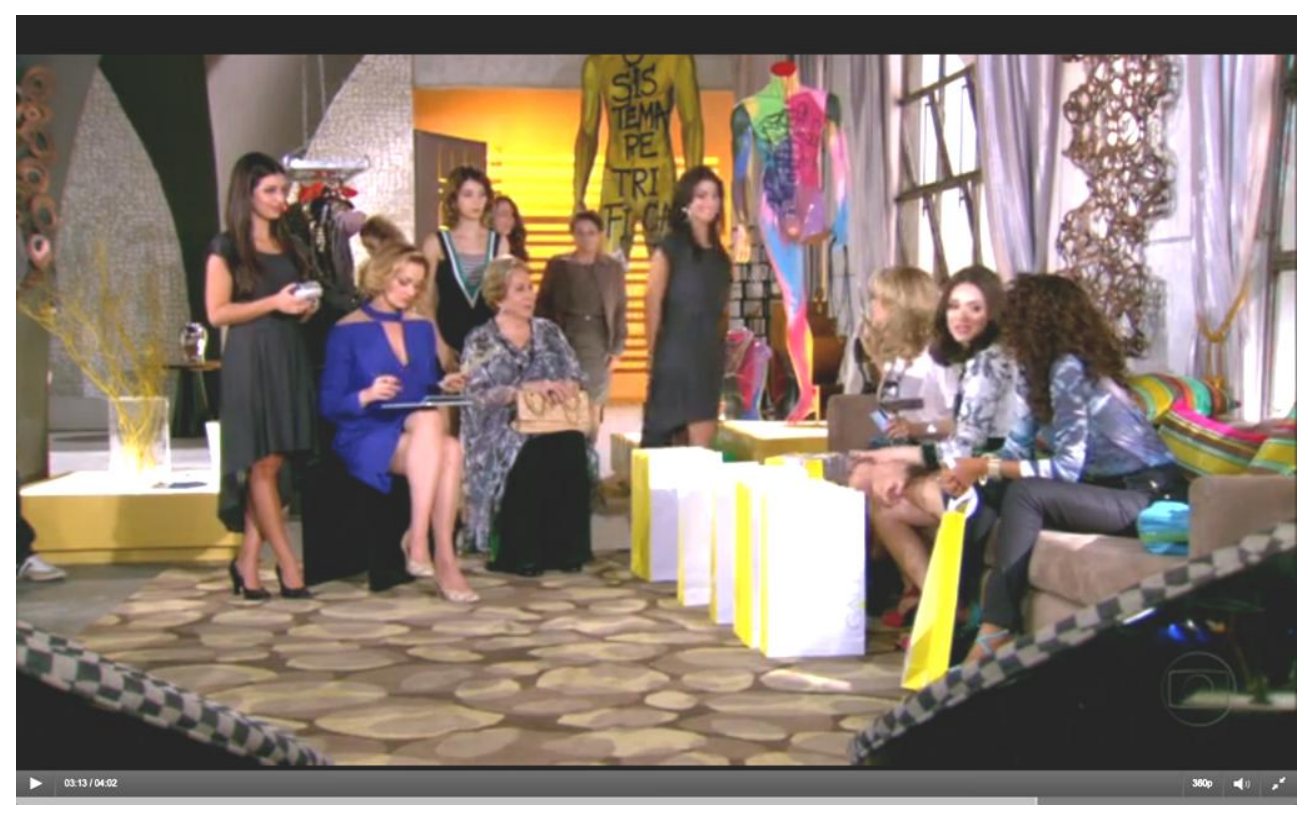

Figura 15 - Empreguetes carregadas de compras na loja Galerie

Fonte: <http://gshow.globo.com/novelas/cheias-de-charme/capitulo/2012/7/23/socorro-falapara-chayene-que-sabe-como-separar-as-empreguetes.html>

Máslova: "Socorro!" - Socorro que está no provador coloca a cabeça para fora - "Eu trouxe umas coisinhas, mas sinceramente acho que aqui não tem nada para uma pessoa como você, não.”.

No fundo toca o som da música tema da personagem Socorro, "United States of Piauí" de Luiz Gonzaga.

Socorro pede para Máslova virar a peça de roupa que ela segura em um cabide: "Vira.".

Ela observa. 
Socorro: “Tu tem razão, visse, Dona Má. Porque uma personal colega de empreguete tem que andar toooda trabalhada no brilho. Não pode andar micha assim não.

Máslova: "Você é que é micha pra mim, viu. Se vira. Cansei!" - e pendura a roupa.

Socorro: "humm" - ela faz um barulho com a boca que lembra um bufar de cavalo. A música para de tocar.

Isadora dirige-se a seu marido: "Sai daqui, Conrado. Sai. Eu falei pra você não ficar aqui, por favor.".

Conrado: "Ahh, vim aqui ajudar a tua família descolar uma grana e você tá me expulsando?".

Isadora faz sinal com as mãos para ele sair: "Sai, sai, Conrado, sai.".

Conrado: "Eita.".

Cida sai do provador com um vestido, passa em frente de Isadora. Conrado permanece de longe olhando.

Máslova: “Ai, esse ficou muuito bom pra você, Maria Apareciiidaaa.”.

Começa a tocar a música tema de Cida, "Piscar o Olho" de Tiê.

Isadora: "É. Até que ficou bonzinho. Mas o que adianta ter um vestido caaaro desses, se você não souber escolher o melhor sapato, o melhor acessório...”.

Cida: "Ah, mas pra isso serviu passar esses anos todos naquela casa. Aprendi muito sobre moda. Agora, me diz uma coisa, Isadora, de que que adianta todo esse bom gosto, se você não tem mais dinheiro pra comprar um vestido como esse aqui? Se você tá aí, me atendendo?".

Cida: "Isadora? Cuidado, viu. O Conrado me largou quando descobriu que eu era pobre, lembra? Agora que vocês tão falidos, será que não vai acontecer a mesma coisa com você?" - Isadora fica com um rosto preocupado e Cida se retira.

Isadora olha para Máslova, que faz um sinal de como quem não pode fazer nada.

Em outro canto da loja as moças comentam sobre as peças. A música para de tocar.

Brunessa (Chandelly Braz): "Rosário! Acho que o que tu tá procurando é isso aqui, não é não?" - ela traz algumas peças.

Rosário: "Exatamente, menina. Ó, isso daqui pra um evento assim com patrocinador, sabe, receber um prêmio. Se eu for pra um evento desse hoje eu nem tenho roupa...".

Cida: "Meninas" - ela aparece provando um novo vestido - "E aí? Que que cês acham?".

Penha: "Meeninaa...mas tu tá linda de bonita, tá chique de fina!". 
Máslova exclama olhando a cena de longe: "Impressionante como essas empregadinhas fazem sucesso!".

Conrado, que está do lado da avó, responde: "Impressionante fui eu ter deixado essa gata passar.”.

Começa a tocar uma música, sem letra.

Isadora interpela Conrado: "Gostou? Eu tenho um igual e você odeia.".

Conrado: "Odeio em você, Isadora, que tem perna fina, aí não combina." - a moça se afasta enraivecida.

Sônia dirige-se a Cida: "Maria Aparecida, esse vestido não foi remarcado.”.

Cida: "Ah, tudo bem, eu vou levar assim mesmo.".

Sônia: "Acho que você não entendeu. Ele não entrou na liquidação e custa quatro mil reais.".

\section{Penha se assusta com o preço e segura a mão de Rosário.}

Cida: "Quem não entendeu foi a senhora, Dona Sônia, eu vou levar o vestido.”.

Rosário: "Leva sim, Cida. Ficou linda.".

Penha se levanta: "Não, não, não...vestido de quatro mil reais tu não vai...." - Ela para ao ver todos a encarando e muda o discurso.

Penha: "Quem pode pode né, minha filha, quem não pode ó..." - ela coloca a mão na cintura e rebola.

Risos.

Cida rindo: "Então, eu vou tirar ali no provador." - ela quase esbarra em Conrado que fica olhando para ela.

Isadora: "Que que essas empreguetes estão fazendo aqui?".

A música para de tocar.

Funcionária Helô: "Salvar o dia, né. Elas tão comprando tudo que tava encalhado.".

Sônia: “O pior é que a Helô tem razão, minha filha. Brunessaaa, vem cá, por favor.”.

Brunessa se aproxima.

Sônia para Brunessa: "Mostra os vestidos da Mecatrom pra Rosário que ela gosta de coisa boa. A moreninha pode esquecer que só faz reclamar de preço.”.

Brunessa: "Pode deixar que eu vou fazer empreguete gastar. Vou levar essa jaqueta que eu já sei que ela gosta.”.

Sônia: "Tem jeito pra venda viu, Brunessa.". 
Uma música animada, sem letra, começa a tocar. As Empreguetes estão entretidas, rindo, sentadas em um sofá da loja, em frente a uma mesa onde se apoiam suas sacolas de compras. Rosário veste minissaia brilhante com uma blusa solta; Cida usa saia também, com uma blusa e um casaco discretos; Penha veste calça jeans justa, com cinto largo, uma blusa de manga comprida justa brilhante e sandálias azuis com salto bem alto.

Rosário: “Ó, Brunessaa, tu tem talento como vendedora, viu. Não, inacreditável, ela achou assim tudo que eu queria, que me favorecia, rapidinho.”.

Brunessa: "Também não é muito difícil né, Dona Sônia.".

Rosário estende o cartão para pagar: "Ó”.

Cida: "Não, amiga. Presente.".

Rosário: "Como assim?".

Cida estende o cartão para pagar.

Rosário: "Não, não, não, pera aí, tá maluca, Cida.".

Cida: "Que é isso.".

Rosário: "Cida, não.".

Cida: "Deixa eu fazer isso. Você fez muito pela gente. Cê dividiu seu sonho com a gente. Cê merece.".

Penha: "É verdade. Amiga, eu num vou te dar presente, porque...assim... eu tenho outras prioridade né, família...”.

As três se abraçam.

Rosário: "Ai, que querida.”.

Socorro traz um vestido com detalhes dourados: "Cidaa, não vai ter nem um agradinho pra mim não?".

Penha: "Socooorooo.".

Cida: "Tudo bem, pode pode incluir.".

Rosário: "Oh, Ciiida.".

Sônia com uma calculadora na mão: "Vai parcelar, Maria Aparecida?".

Cida: "Não. Pode passar à vista mesmo.".

Isadora furiosa encara Conrado e sai do ambiente.

Um celular começa a tocar e acaba a cena. 
Nessa cena, na significação acional temos a representação de um gênero cotidiano, primário, de um atendimento em loja. Toda a ação é sustentada pelo ritual de consumo de compra de roupas e a posse efetiva do poder de crédito. As Empreguetes junto de Socorro fazem compras na loja luxuosa da personagem Sônia, que passa por problemas financeiros e coloca suas peças em liquidação. O inusitado é a inversão de papéis, Sônia e Isadora eram patroas de Cida no passado e Máslova também já fora patroa de Socorro.

Nesse instante, são as ex-patroas que servem as ex-empregadas. Por isso, há um desconforto por parte das ex-patroas e satisfação por parte das ex-empregadas domésticas que estão em melhor situação.

Como expõe o filósofo russo Bakhtin (2003), os gêneros são diferentes em função da situação, da posição social e das relações entre os participantes da situação. Nessa simulação de um gênero primário de atendimento em loja, o esperado é que uma pessoa de uma classe social humilde atenda alguém de uma classe superior abastada que pode gastar dinheiro. Aqui, embora no momento as Empreguetes tenham mais dinheiro, as relações marcadas pela classe de origem e pelo trabalho doméstico ainda estão presentes no desconforto das ex-patroas.

No início, Máslova atende Socorro e comenta que não há nada para ela. Subentende-se que ela quis dizer que o gosto e estilo da personagem não condizem com a qualidade e sofisticação das roupas da Galerie. Há comédia na cena, pois Socorro fala em tom de ordem com a ex-patroa, "vira", e rebate afirmando que as roupas que Máslova está mostrando são "michas" e não combinam com uma personal colega de empreguete que precisa andar toda "trabalhada no brilho".

Máslova perde a paciência com Socorro, o que não aconteceria se fosse outra cliente. Além disso, Socorro chama Máslova de "Má" em uma pretensão de intimidade o que também torna o trecho engraçado, pois foge tanto da relação entre ex-empregada com ex-patroa como da relação entre atendente e atendido na loja.

A música tema da personagem ajuda a conferir o tom cômico ao trecho e a marcar a personalidade de Socorro. Pois a letra da canção "United States of Piauí" de Luiz Gonzaga condiz com a caracterização da personagem que é natural de Sobradinho, no Piauí.

No trecho da conversa entre Isadora e Cida. A primeira, com ciúme, pelo fato do vestido ter ficado belo na moça, questiona a validade de ter um vestido caro se ela não 
souber combinar com os melhores acessórios. A fala indica que Cida não fora sempre rica e por isso não possui noção de moda e bom gosto como Isadora que sempre teve boas roupas. A colocação remete a um enriquecimento econômico deslocado da aquisição de capital cultural.

Porém, Cida rebate com a alegação de que os anos passados como empregada na casa de Isadora serviram para que ela aprendesse sobre moda. Em seguida, ela provoca e questiona Isadora: "Agora, me diz uma coisa, Isadora, de que que adianta todo esse bom gosto, se você não tem mais dinheiro pra comprar um vestido como esse aqui? Se você tá aí, me atendendo?”.

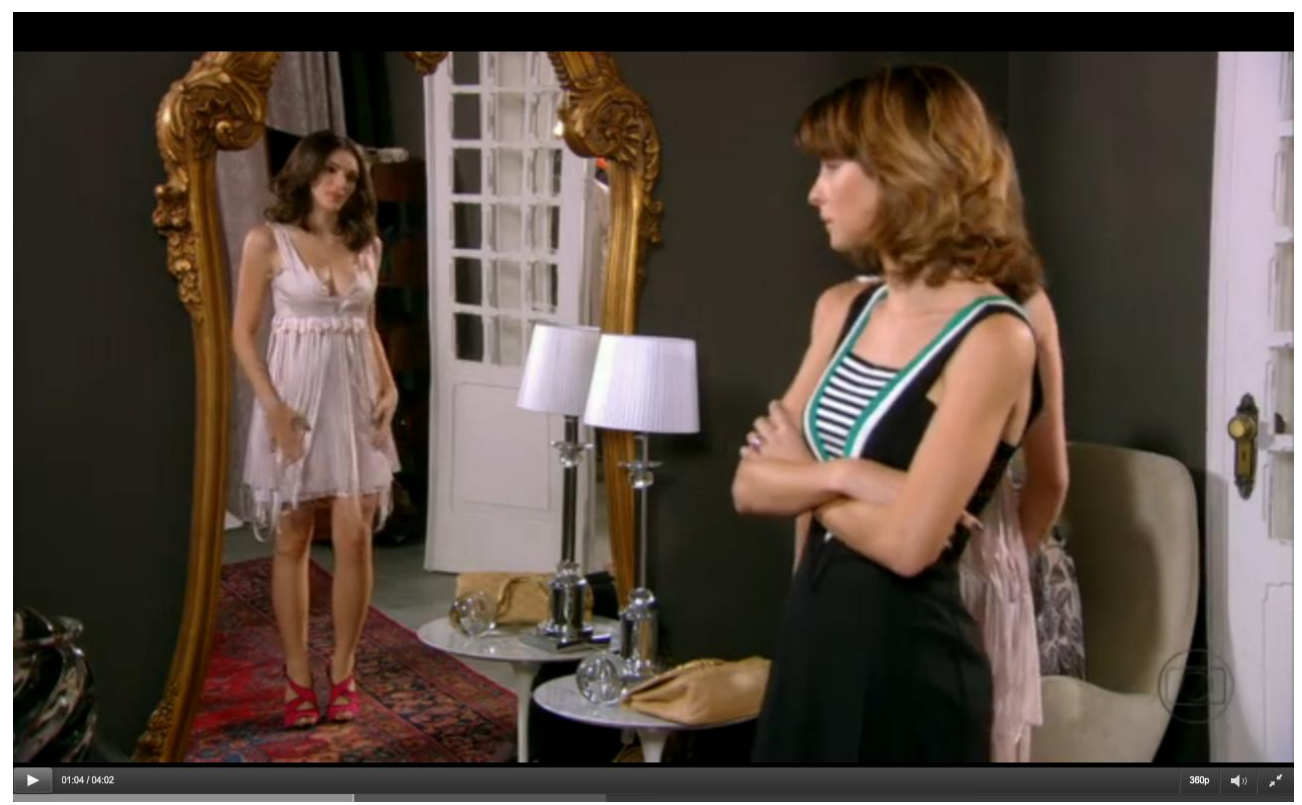

Figura 16 - Isadora observa Cida provar vestido Fonte: <http://gshow.globo.com/novelas/cheias-de-charme/capitulo/2012/7/23/socorro-falapara-chayene-que-sabe-como-separar-as-empreguetes.html>

Cida ainda alerta a moça para o risco de perder o marido agora que não tem dinheiro, pois o mesmo a abandonara em outra ocasião quando descobriu que Cida era pobre. As falas da moça reforçam a inversão de papéis sociais e o tom de vingança, já que Cida sofrera na casa de Isadora.

Temos um exemplo, assim, de uma forma moral e personalista de tratar as relações de classe, presente na telenovela em geral, conforme explica Ronsini (2012), pois Isadora que não era merecedora de riqueza empobreceu e Cida, moça de boa índole, enriqueceu e agora se vinga por sempre ter sido rebaixada na casa da ex-patroa.

A personagem Brunessa é transmitida com simpatia na cena, ela está feliz, não se importa em atender as Empreguetes e demonstra habilidade com vendas. Essa 
personagem é sobrinha de Ivone, amiga de Penha e está na loja só para ajudar as vendas na queima de estoque. Ela também mora no Borralho e começou a trabalhar de empregada doméstica na casa de Sônia com a saída de Cida. Ela sempre tivera o desejo de trabalhar na Galerie, mas não conseguia por ser de origem humilde e não ter boas indicações.

Esse trecho, então, mostra uma revanche também de Brunessa, que já fora rebaixada em outras ocasiões na própria loja e, agora, se mostra talentosa. Rosário elogia a habilidade da moça em encontrar tudo que lhe favorece, bem como Sônia que admite que ela tem habilidade para venda.

Além disso, Cida aparece sempre bonita nas roupas experimentadas e chama a atenção de Conrado, provocando o ciúme de Isadora. Isso demonstra que a mudança de Cida não traz apenas possibilidade de fazer boas compras e humilhar Isadora financeiramente, mas também no amor, visto que Conrado a namorara antes.

O rapaz expõe inclusive: "Impressionante fui eu ter deixado essa gata passar". E ainda diz que o mesmo vestido que Cida experimenta fica feio para a esposa que tem perna fina.

Rosário, por sua vez, é considerada a de melhor gosto por Sônia, uma vez que é atraída pelas peças caras. Enquanto isso, Penha é a única que se espanta com os valores e demonstra desconforto. Sonia, inclusive se refere a ela como a moreninha que só faz reclamar de preço. Quando Penha se levanta para protestar contra o valor de quatro mil reais do vestido, ela é repreendida pelo olhar das pessoas e, então, recua e brinca.

Penha também expõe nessa cena seu vocabulário popular "Meeninaa...mas tu tá linda de bonita, tá chique de fina!”. Ela também demonstra não poder dar presente para Rosário como Cida faz porque tem "outras prioridade", como família. Assim, demonstra a marca da classe de origem, com seu jeito popular e o capital econômico que outrora fora escasso e faz com que ela se espante com valores muito altos para vestimenta.

Quando Cida reforça a Sônia que quer levar o vestido mesmo sem a liquidação e afirma ainda que pagará à vista, a cena traz novamente a inversão dos papéis sociais e o sentido de revanche pelo viés moral e personalista, desvinculado da vivência de classe social. 


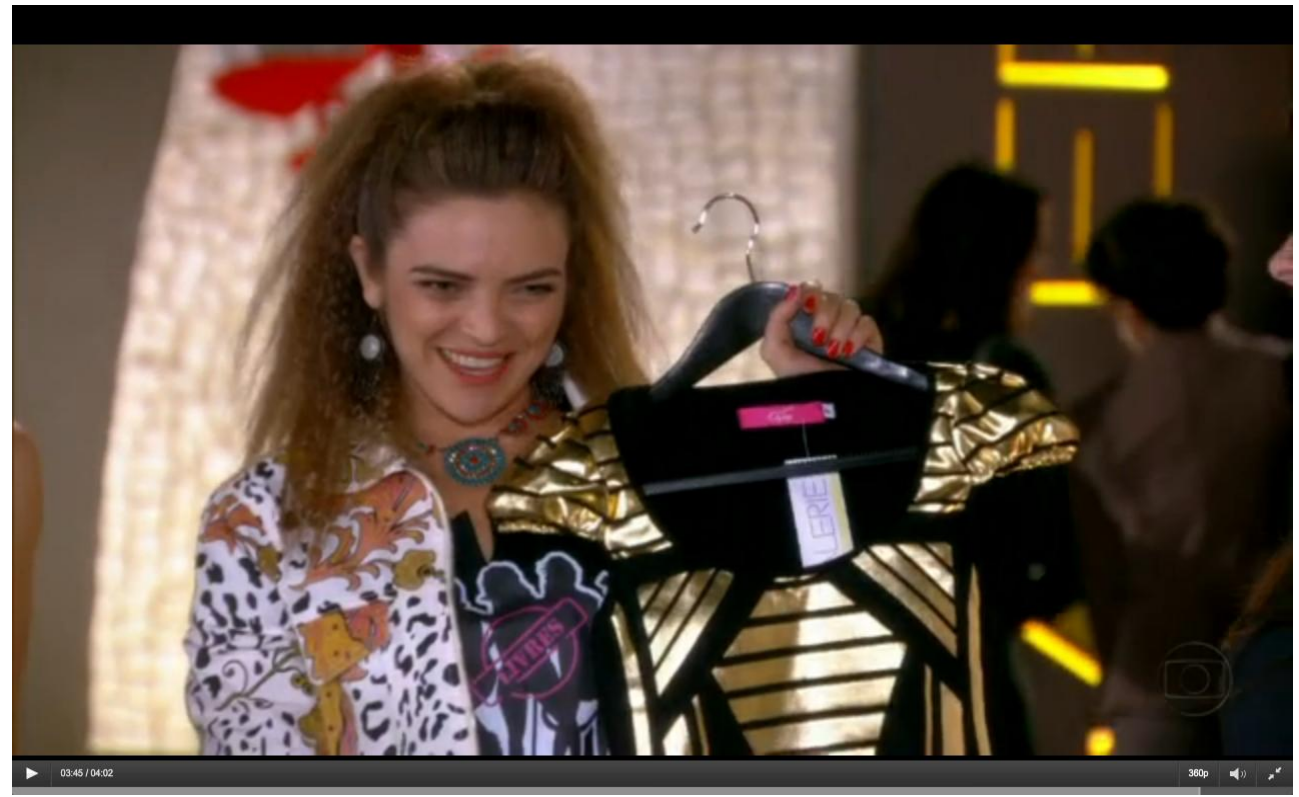

Figura 17- Socorro pede vestido de presente para Cida Fonte: <http://gshow.globo.com/novelas/cheias-de-charme/capitulo/2012/7/23/socorro-falapara-chayene-que-sabe-como-separar-as-empreguetes.html>

A mesma ideia é enfatizada pelo fato dela querer dar o presente para Rosário e também para Socorro, pois Sonia, a dona da loja, fora sua patroa. Logo, nada melhor do que mostrar para ela, que já a maltratara, que agora tem recursos financeiros de sobra. Já o tom cômico reaparece no final com Socorro, que traz um vestido dourado e pede de presente para Cida.

É pertinente enfatizar que apenas Socorro e Penha destoam do ambiente pelo comportamento e impressões. Rosário e Cida parecem que sempre fizeram compras em lojas luxuosas, tamanha é a familiaridade, conforto e integração das duas. Isso demonstra que a construção das personagens Rosário e Cida não está baseada de maneira contundente nas relações sociais de classe, diferente de Penha e Socorro que, nessa cena, demonstram quem são e de onde vieram.

Ademais o nome da cena "Sônia e Máslova ficam horrorizadas com as ironias de Penha" condiz com uma pequena parte da gravação e, inclusive, é possível dizer que nem houve ironia de fato na fala de Penha. Ela se chocou com o valor somente. A ironia está presente no próprio fato das ex-empregadas terem dinheiro e serem atendidas por suas ex-patroas falidas. A ironia é reforçada pela postura esbanjadora de Cida.

Desse modo, na significação identificacional temos o ethos irônico comentado acima, presente na cena desde o início pelo fato da inversão dos papéis sociais, das expatroas estarem servindo suas ex-empregadas. Há também o ethos personalista, pois a 
cena sugere que os conflitos de classe são resolvidos por via moral, os ruins tornam-se pobres e os bons ricos, como argumenta Ronsini (2012) a respeito da telenovela.

Há ainda o ethos individualista, pois embora Penha e Socorro mostrem suas raízes de classe pelos modos populares, o tom da cena é dado por Cida e Rosário (e até mesmo por Brunessa) que estão integradas à loja luxuosa, desvinculadas da realidade do emprego doméstico e de classe, se sentem à vontade, têm bons modos, e, inclusive, entendem de moda, como é o caso de Cida que aprendeu tudo sobre o assunto enquanto foi empregada no Casa Grande. As características de Penha e Socorro, por esse ângulo, parecem também atributos individuais das personagens, sem vínculo social.

Assim, na significação representacional, o discurso dessa cena relaciona-se com a ideologia meritocrática e do desempenho (RONSINI, 2012), pelo ethé individualista e personalista e pela ironia da inversão de papéis na loja, transmitida de modo idealizado e romântico, o que é peculiar ao gênero melodramático de um modo geral.

Desse modo, as cenas analisadas de Cheias de Charme apontam para um discurso mais tradicional comum à telenovela na representação de classe. Maria da Penha é a única das três empregadas principais que mostra vínculo com a vivência de classe, reforçado pela comunidade Borralho.

Ademais, nas cenas analisadas, foi possível perceber a representação dos gêneros primários mais conectados com a narrativa geral da trama e menos informalidade e familiaridade entre os personagens em comparação a Avenida Brasil. Também houve, nos fragmentos selecionados, mais cortes, ou seja, mais tomadas, e maior utilização de músicas para marcar o clima das cenas.

É importante explicar que analisamos situações diferentes em ambas as tramas, em Avenida Brasil foram estudadas as cenas familiares e em Cheias de Charme cenas de interação entre as três empregadas principais.

Mesmo assim, acredita-se ser válida a comparação, porque em Avenida Brasil, a família analisada era a principal da trama, os personagens integrantes da família quase nunca se encontravam fora do Divino (com exceção de algumas cenas, como a de Cabo Frio), as cenas familiares eram recorrentes, além de quase todos os personagens da telenovela viverem também no suburbano Divino (LOPES; MUNGIOLI, 2013).

Já em Cheias de Charme, as três personagens e empregadas principais da trama eram Maria Aparecida, Maria da Penha e Maria do Rosário. Embora termos identificado que Maria da Penha era a única com características compatíveis com a caracterização da 
nova classe trabalhadora, seu discurso só se destaca em comparação às outras duas personagens principais. Procurou-se, assim, realizar uma análise que buscasse o tom geral da trama e não permanecesse circunscrita a um universo particular que não era o mesmo das outras duas personagens principais.

Isto posto, partiremos para as considerações finais. 


\section{CONSIDERAÇÕES FINAIS}

Procuramos com as análises realizadas levantar as nuanças da midiatização do consumo e do sentido de classe social de determinadas cenas de Avenida Brasil e Cheias de Charme. A palavra nuanças é empregada no sentido de ressaltar que as formações discursivas não são homogêneas e sim heterogêneas (MAINGUENEAU, 1989). Os discursos analisados são compostos por diversas vozes que se opõem e se sobrepõem, já que o outro é uma realidade constitutiva do discurso (BAKHTIN, 2002).

Desse modo, buscou-se mostrar diferentes aspectos discursivos nas cenas analisadas que poderiam tanto corroborar com a visão economicista e meritocrática hegemônica de classe social (RONSINI, 2012; SOUZA, 2012) como com elementos que dialogassem com o que é atribuído à nova classe trabalhadora pelo sociólogo Souza (2012), além da maneira peculiar da telenovela tratar as desigualdades sociais (ROSINI, 2012) e formas que mostrassem mudanças quanto a essa convenção.

A análise discursiva com base no materialismo histórico e dialético marxista (teorias de Bakhtin, Análise do Discurso Francesa e Análise do Discurso Crítica) se mostrou pertinente para a tarefa proposta, pois entende o discurso como um produto social e histórico dado pelas concepções hegemônicas e também como possibilidade de inovação, de fazer história, o que ressalta o discurso enquanto prática social (FAIRCLOUGH, 2001).

Assim, concebemos o discurso pelas dimensões textual, da prática discursiva e da prática social e, respectivamente, pelas significações acional, identificacional e representacional (RESENDE; RAMALHO, 2005). Na primeira dimensão, trouxemos o enunciado e sua relação com o gênero; no segundo nível as identidades pelo conceito de ethos e a correspondência com a prática discursiva - também entendida como enunciação, as condições de produção do enunciado - e na dimensão da prática social trouxemos a representação de mundo presente no discurso.

Se em alguns momentos as significações e dimensões discursivas pareceram misturadas na análise e pouco marcadas, acredita-se que se deva ao fato delas se relacionarem dialeticamente e não isoladamente e, assim, a separação ser mais uma perspectiva analítica, que não exclui a interiorização entre elas (RESENDE; RAMALHO, 2005, p. 34). 
Desse modo, em Avenida Brasil, a análise da primeira cena mostra as contradições de uma família marcada pela posição social de origem popular, com um viés cômico e irônico também. De um modo geral, o discurso da cena não contribui com a visão individualista hegemônica que naturaliza comportamentos burgueses como atributos individuais, deslocados da vivência de classe (SOUZA, 2012).

A segunda cena também demonstra, com um tom cômico, o papel da família na reprodução das disposições populares, o que corrobora com atribuições dadas à nova classe trabalhadora por Souza (2012).

A terceira cena de Avenida Brasil, por sua vez, traz o discurso de um gosto estético popular atrelado ao cotidiano e às sensações, desvinculado, de um modo geral, do julgamento cultural considerado legítimo e dominante, mas atrelado à classe de origem dos personagens e à falta de reconhecimento e conhecimento da cultura dita legítima. O aspecto popular atrelado ao cotidiano é perceptível nos outros trechos, nas situações que aludem ao consumo alimentar e cultural dos personagens, bem como pelo ritual de uso e decoração da moradia onde vivem.

A análise de Avenida Brasil, dessa forma, mostrou a predominância do ethos popular e cômico, vinculado às disposições de origem da família e a um capital cultural de classe popular. Houve diálogo, de um modo geral, com o que Jessé Souza (2012) atribui às novas classes trabalhadoras em sua pesquisa.

Apesar disso, percebeu-se a reprodução de posições hegemônicas do racismo de classe em alguns aspectos no personagem Leleco. Porém, tal reprodução não se mostrou relevante no discurso como um todo.

É importante ressaltar que o aspecto popular transmitido em Avenida Brasil se entrelaça à simulação do gênero primário dentro da telenovela, pois, a conversa informal, trivial e corriqueira foi recorrente nas três cenas e indicaram a familiaridade e os modos populares dos personagens. As falas altas e ao mesmo tempo reforçam a informalidade.

Conforme elucidado no capítulo anterior, é possível sugerir, pelos aspectos levantados, indicações de inovação na simulação do gênero primário dentro de Avenida Brasil. Ainda que tal afirmação exija maior aprofundamento, existe a percepção indicativa e sugestiva de tal dado.

Embora nas cenas analisadas de Avenida Brasil não tenha havido muitas referências à peculiaridade da telenovela em tratar as desigualdades sociais, comentadas por Ronsini (2012), sabemos que na prática discursiva narrativa havia elementos que 
corroboraram com isso, como o fato do personagem Cadinho ter se mudado para o Divino e o final feliz no bairro suburbano, reforçando a reprodução das desigualdades de forma humanizada (RONSINI, 2012).

Mesmo assim, de um modo geral, há indícios de que a telenovela inovou no modo de tratar as desigualdades e a nova classe trabalhadora, como o fato da maioria dos personagens serem do Divino e a convivência no bairro suburbano ser bastante explorada na trama. Além disso, houve a inclusão da classe social chamada por Jessé Souza provocativamente de ralé (SOUZA, 2012), com a representação do lixão, que coloca em cena os indivíduos que vivem da ritualização do descarte do consumo alheio como lugar social de significação menor.

É possível dizer que a oposição entre ricos e pobres de maneira individualista, fora do contexto social, foi menos marcada também nessa telenovela. $\mathrm{O}$ enriquecimento da família de Tufão não se fez central na narrativa, que enfatizou a vingança de Nina contra Carminha. Houve maior exploração do cotidiano da família e dos costumes populares dos personagens no contexto de classe, como foi demonstrando nas três cenas analisadas, com menos confronto pessoal entre personagens ricos e pobres. Temos, assim, um quadro geral sobre como Avenida Brasil representou a nova classe trabalhadora e seu consumo.

É pertinente frisar que a atribuição de representantes da "nova classe média" aos personagens de Avenida Brasil e Cheias de Charme foi feita pela própria mídia, em matérias jornalísticas, por exemplo. Embora a renda da família ficcional de Tufão ultrapassasse a renda dos reais representantes da população que ascendeu economicamente no Brasil, consideramos a família ficcional como uma representante da considerada "nova classe C" desde o início.

Mesmo porque, conforme expusemos teoricamente no primeiro capítulo, a renda não é o determinante de uma classe social, como bem mostrou a própria trama ao corroborar com a visão de Souza (2012) na exposição de uma família que ascendeu financeiramente, mas continuou vinculada à classe de origem, pois não compartilha em sua formação do mesmo capital econômico e cultural das classes médias.

Apesar disso, a representação do enriquecimento com o jogo de futebol não condiz com a maneira como os batalhadores ascenderam economicamente, com base em muito trabalho, sacrifício e com a ajuda de políticas governamentais (SOUZA, 2012). Assim, a representação do futebol na telenovela pode ser considerada uma forma 
típica do folhetim eletrônico trazer a ascensão financeira à narrativa, mais atrelada a situações individuais e pouco comuns no dia a dia real.

Dessa forma, existem elementos em Avenida Brasil puramente midiáticos, de pouca consistência sociológica para validar o termo "nova classe C" e que é peculiar à telenovela, na forma de retratar a nova classe trabalhadora, como os explicitados acima, bem como aspectos que corroboram com a visão hegemônica, mais especificamente do racismo de classe (SOUZA, 2012). Além disso, há o elemento cômico nas cenas selecionadas, que pode ser considerado uma forma ficcional de tratar os costumes de classe, uma maneira de criar empatia com o público.

Apesar das ressalvas, é possível dizer que a grande parte do que foi levantado na análise de Avenida Brasil condiz com os argumentos sociológicos comentados no primeiro capítulo e contribuem, assim, para um discurso que propõe mudanças, até mesmo no que diz respeito à simulação do gênero primário dentro da telenovela, como exposto anteriormente.

Passemos, assim, para os resultados da segunda telenovela analisada, Cheias de Charme. A análise da primeira cena identificou um discurso que ressalta de forma romântica a possibilidade de superação das dificuldades sociais, por meio da vontade individual, além da exaltação das relações pessoais para tratar do tema desigualdade, uma vez que as falas predominantes na cena e o pacto realizado indicam a oposição entre empregadas domésticas e patroas e a vontade das primeiras de estarem no lugar das segundas. O discurso, como explicado no capítulo anterior, nos remete ao economicismo dominante discutido por Jessé Souza (2012) e ao personalismo no modo de tratar as diferenças, elucidado por Ronsini (2012). Trata-se do projeto empreendedor na lógica individual.

$\mathrm{Na}$ segunda cena, temos o aspecto popular e o tom comunitário que condizem com o que Souza (2012) argumenta sobre o espírito comunitário e o capital cultural da nova classe trabalhadora. Apesar disso, há a reprodução do racismo de classe discutido por Souza (2012) por meio da figura do malandro Sandro, além de existir na cena a ideia de que a comunidade é um local mais feliz que os lugares ricos, o que indica um reforço da reprodução das diferenças sociais em tom humanizado, o que é comum à telenovela, na visão de Ronsini (2012), e que se soma ao sonho de consumo da conquista da moradia e do acesso aos bens de consumo como signos do bem-estar.

Já a terceira cena analisada de Cheias de Charme transmite um discurso predominante que se relaciona com a ideologia meritocrática e do desempenho 
(RONSINI, 2012), pois há a prevalência do individualismo, que desloca as personagens ex-empregadas do contexto de classe social. A cena também realça as relações pessoais na representação das desigualdades, presente na inversão de papéis na loja e na ideia de que os bons tornam-se ricos e os ruins pobres. Aspectos esses transmitidos de modo idealizado e romântico na encenação do ritual de compra de roupas de luxo e no poder de uso do crédito.

Desse modo, é possível sugerir que Cheias de Charme aponta para um discurso mais tradicional comum à telenovela na representação de classe, sendo Maria da Penha a única das três empregadas principais que mostra vínculo com a vivência de classe, reforçado pela comunidade Borralho, o que se relaciona em determinados aspectos com o que Jessé Souza (2012) argumenta sobre a nova classe trabalhadora.

Também nessa telenovela, a simulação dos gêneros primários está mais conectada com a narrativa geral da trama. Houve mais referências à narrativa, mais tomadas e cortes, maior utilização de música para marcar o clima das cenas, e menos informalidade e familiaridade entre os personagens em comparação a Avenida Brasil.

Apesar disso, como pontuamos anteriormente, sabe-se pela prática discursiva narrativa, que Cheias de Charme trouxe à tona a centralidade do emprego doméstico em sua trama, o que não é comum nas telenovelas. Por meio de Maria da Penha, a história explorou os direitos trabalhistas das empregadas domésticas em alguns momentos, sobretudo no comercial realizado pela personagem em parceria com sua ex-patroa Lygia.

Penha foi representada inserida na comunidade Borralho, trazendo para a trama a retratação dos costumes populares da nova classe trabalhadora, a ética do trabalho, o capital cultural de origem e o espírito comunitário (SOUZA, 2012).

Porém, de um modo geral, a forma narrativa e as cenas analisadas trouxeram a predominância do individualismo, da supremacia das relações pessoais e do moralismo no tratamento das classes sociais, e a reprodução das desigualdades em um tom humanizado (RONSINI, 2012). Tudo isso embalado por um tom romântico e idealizado.

Esses dados corroboram com o modo característico da telenovela tratar as desigualdades (RONSINI, 2012) e também com o modo individualista e economicista de enxergar as diferenças sociais (SOUZA, 2012).

As peculiaridades midiáticas da telenovela estão presentes no enriquecimento fantasioso das Empreguetes como cantoras, nos estereótipos dos bons que enriquecem e 
dos ruins que empobrecem e na solução pacificadora para os conflitos. Esses elementos reforçam a visão hegemônica de classes sociais em nossa sociedade por meio do individualismo já explicitado, o que corrobora com a meritocracia e ideologia do desempenho (SOUZA, 2012; RONSINI, 2012). Assim, a análise de Cheias de Charme demonstrou um discurso que aponta pouco para mudanças.

Desse modo, de forma geral, temos na midiatização do consumo e do sentido de classe social das duas telenovelas elementos que corroboram com a visão hegemônica de classe social na sociedade capitalista atual, características comuns à telenovela na forma de tratar as desigualdades e aspectos que partilham da visão dos sociólogos sobre o que seriam as classes sociais "despidas" das ideologias dominantes. Estes últimos apontam para mudanças no modo de tratar as classes na telenovela e podem até mesmo se entrelaçar com os gêneros dentro da trama, como ocorreu em Avenida Brasil.

Da perspectiva da midiatização, é possível sugerir que o consumo e o sentido de classe representados por ambas as produções repercutem no modo como a narrativa da nação (LOPES, 2004) é construída no imaginário dos brasileiros. Por esse prisma, Avenida Brasil e Cheias de Charme trouxeram contribuições, de maneiras diversas, para a construção do imaginário de classe no Brasil.

É possível sugerir que, como parte de um sistema midiático, as telenovelas aqui expostas colaboraram, assim, para o conhecimento do que seria a nova classe trabalhadora brasileira, por meio das nuanças indicadas nesta dissertação. Elas cooperaram para a construção de um conhecimento do brasileiro sobre ele próprio e sua nação, o que corrobora com a visão de José Braga (2006) acerca da construção da realidade social por meio dos processos interacionais de referência, que cada vez mais se concentram na mídia.

Ademais, como comentado no primeiro capítulo - dado o potencial cultural da telenovela no Brasil, a relevância do tema "nova classe C" na representação ficcional e na mídia nacional e internacional também - acredita-se que tramas como Avenida Brasil e Cheias de Charme colaboram com a midiatização do consumo e do sentido de classe social nos termos macrossociais trazidos por Braga (2006) e também de forma indireta, como explica Hjarvard (2012), que se refere à influência da mídia em determinada atividade sem interferência direta na execução de tarefas. No caso, a influência da mídia sobre o conhecimento de classe no Brasil, que propositalmente não favorece mudanças 
ou transformações, pois o dispositivo ${ }^{22}$, de modo geral, traz a lógica hegemônica das elites.

Emergem, então, as seguintes perguntas: como essa lógica do dispositivo da telenovela se faz circular? Como se dá o horizonte da recepção que busca dar conta da totalidade dessa midiatização? Como os diferentes rituais cotidianos de consumo representados na telenovela articulam os sentidos de consumo e de classe social na vida das pessoas? Como as representações ritualísticas de usos e consumo na telenovela repercutem no cotidiano de pessoas pertencentes a determinada realidade social, por exemplo?

Caberia, como uma etapa seguinte para contribuir com os estudos de recepção da área, estudar a forma como esses discursos da telenovela são processados pelos telespectadores de diferentes classes sociais, quais são as nuanças na forma de leitura desses sentidos de consumo e classe social e como eles são ressignificados. Inclusive, seria oportuno aprofundar a relação entre representação de classe e consumo, no intuito de compreender como opera a simulação na telenovela de rituais populares cotidianos de consumo na midiatização do consumo e do sentido de classe social. Seria pertinente estudar como se daria a circulação dos processos dessa midiatização com o aporte das teorias de Braga (2006) e Hjarvard (2012) e da concepção transdisciplinar de ritual de consumo argumentada por Trindade e Perez (2013), que remete tanto à dimensão antropológica quanto à dimensão comunicacional e seus novos horizontes de exploração teórica, como dispositivos. No caso, o dispositivo telenovela e seus desdobramentos de sentido de consumo e classe social.

\footnotetext{
${ }^{22}$ Ver explicação sobre o conceito dispositivo no rodapé da página 66.
} 


\section{REFERÊNCIAS}

AGAMBEN, Giorgio. O que é o contemporâneo? E outros ensaios. Chapecó: Argos, 2010.

ALMEIDA, Heloisa B. de. Telenovela, Consumo e Gênero. Bauru, SP: EDUSP, 2003.

ANDRADE, Roberta Manuela Barros de. O Fascínio de Sherazade: os usos sociais da telenovela. São Paulo: Annablume, 2003.

ANTUNES, Ricardo. Adeus ao trabalho? Ensaios sobre as metamorfoses e a centralidade do mundo do trabalho. São Paulo: Cortez/Edunicamp, 1995.

ANTUNES, Ricardo. Os sentidos do trabalho. Ensaio sobre a afirmação e a negação do trabalho. São Paulo: Boitempo, 2001.

AUTHIER-REVUZ, Jacqueline. Hétérogéneité montrée et hétérogénéité constitutive : elements pour une approche de lá autre dans le discours. DRLAV, n. 26, p. 91-115, 1982.

BACCEGA. MARIA A. Palavra e discurso. História e Literatura. São Paulo: Ática, 1995.

BAKHTIN, Mikhail. Estética da Criação Verbal. Tradução: Paulo Bezerra. São Paulo: Martins Fontes, 2003.

BAKHTIN, Mikhail. Questões de Literatura e de Estética. A teoria do romance. São Paulo: Hucitec Editora, 2010.

BAKHTIN, Mikhail (V. N. Volochinov). Marxismo e Filosofia da Linguagem. São Paulo: Hucitec Annablume, 2002.

BALOGH, Anna Maria. Discurso Ficcional na TV: Sedução e Sonho em Doses Homeopáticas. São Paulo: Editora da Universidade de São Paulo, 2002.

BOURDIEU, Pierre. A Distinção: crítica social do julgamento. Tradução: Daniela Kern; Guilherme F. Teixeira. São Paulo: Edusp; Porto Alegre: Zouk, 2007.

BRAGA, José Luiz. Sobre mediatização como processo interacional de referência. In:Encontro Anual da Associação Nacional dos Programas de Pós-graduação em Comunicação - Compós, 2006, Bauru SP. Anais XV Compós Encontro Anual da Associação Nacional dos Programas de Pós-Graduação em Comunicação. Bauru, SP: Compós, 2006. p.16.

BRAIT, Beth. Análise e teoria do discurso. In: BRAIT, Beth (org.). Bakhtin. Outros conceitos-chave. São Paulo: Contexto, 2012.

BRAIT, Beth; Melo, Rosineide de. Enunciado/enunciado concreto/enunciação. In: BRAIT, Beth (org.). Bakhtin. Conceitos-chave. São Paulo: Contexto, 2005. 
BRANDÃO, Helena Nagamine. Introdução à análise do discurso. Campinas: Editora da UNICAMP, 2002.

BRANDÃO, Helena Nagamine. I - Conceitos e fundamentos. Enunciação e construção do sentido. In: FÍGARO, Roseli A. (org.). Comunicação e análise do discurso. São Paulo: Contexto, 2012.

CAMPBELL, Colin. A ética romântica e o espírito do consumismo moderno. Tradução de Mauro Gama. Rio de Janeiro: Rocco, 2001.

CHARAUDEAU, Patrick. Discurso das Mídias. Tradução: Angela M. S. Corrêa. São Paulo: Contexto, 2012.

CLASSE C NO HORÁRIO NOBRE. Revista Veja, São Paulo, n.17, p. 11, 25 abril, 2012 .

COULDRY, Nick; HEPP, Andreas. Conceptualizing mediatization: contexts, traditions, arguments. Communication Theory, v. 23, Issue 3, p. 191-201, 2013.

COURTINE, Jean-Jacques. Análise do Discurso Político. O discurso comunista endereçado aos cristãos. São Carlos: Edufscar, 2009.

DAMATTA, Roberto. A casa e a rua: espaço, cidadania, mulher e morte no Brasil. Rio de Janeiro: Rocco, 1997.

DE CERTEAU, Michel. A invenção do cotidiano. Tradução: Ephraim Ferreira Alves. Rio de Janeiro: Editora Vozes, 1998.

DISCINI, Norma. Ator, aspecto, estilo. Estudos Linguísticos XXXV, p. 1544-1553, 2006.

ECO, Umberto. Socialismo y consolación. Barcelona: Tusquets, 1970.

FAIRCLOUGH, Norman. Discurso e mudança social. Tradução: Izabel Magalhães. Brasília: Universidade de Brasília, 2001.

FAIRCLOUGH, Norman; WODAK, Ruth. Análisis crítico del discurso. In: VAN DIJK, Turn A. (org.). El discurso como interacción social. Estudios sobre el discurso II. Una introducción multidisciplinaria. Barcelona: Editorial Gedisa, 2000.

FIGARO, Roseli A.; GROHMANN, Rafael. O Conceito de Classe Social nos Estudos de Recepção Brasileiros. In: Encontro Anual da Associação Nacional dos Programas de Pós-Graduação em Comunicação - Compós, 2013, Salvador. Anais XXII Compós Encontro Anual da Associação Nacional dos Programas de Pós-Graduação em Comunicação. Salvador: Compós, 2013. p.15.

FIORIN, José Luiz. Interdiscursividade e Intertextualidade. In : BRAIT, Beth (org.). Bakhtin. Outros conceitos-chave. São Paulo: Contexto, 2012.

FOUCAULT, Michel. Microfísica do Poder. São Paulo: GRAAL, 2012.

FREYRE, Gilberto. Casa Grande \& Senzala: formação da família brasileira sob o regime da economia patriarcal. São Paulo: Global, 2006. 
GRAMSCI, Antônio. Cultura y Literatura. Barcelona: Península, 1977.

GRAMSCI, Antônio. Selections from the prison notebooks. Londres: Lawrence and Wishart, 1971.

GREGOLIN, Maria do Rosário. Bakhtin, Foucault, Pêcheux. In : BRAIT, Beth (org.). Bakhtin. Outros conceitos-chave. São Paulo: Contexto, 2012.

GREGOLIN, Maria do Rosário. Foucault e Pêcheux na Análise do Discurso: Diálogos \& Duelos. São Paulo: Claraluz, 2006.

GROHMANN, Rafael. O conceito de classe social no marxismo: correntes e atualidade. Cadernos de Pesquisa Interdisciplinar em Ciências Humanas, Florianópolis, Santa Catarina, v.14, n.105, p.3-18, ago./dez. 2013.

HAMBURGER, Esther. Diluindo fronteiras: a televisão e as novelas no cotidiano. In: SCHWARCZ, Lilia Moritz (org.) História da Vida Privada no Brasil. São Paulo: Companhia das Letras, 1998.

HJARVARD, Stig. Midiatização: teorizando a mídia como agente de mudança social e cultural. Matrizes, São Paulo, v. 5, n.2, p. 53-92, jan/jun. 2012.

HOLANDA, Sérgio Buarque de. Raízes do Brasil. São Paulo: Companhia das Letras, 2002.

JUNQUEIRA, Lília. Desigualdades Sociais e Telenovelas. Relações Ocultas entre ficção e reconhecimento. São Paulo: Annablume, 2009.

LEAL, Ondina Fachel. A Leitura Social da Novela das Oito. Porto Alegre: Antropologia Social - UFRGS, 1983. 167 p.

LEONTIEV, Alexis. O desenvolvimento do psiquismo. São Paulo: Centauro, 2004.

LOPES, Maria Immacolata Vassallo de. Para uma revisão das identidades coletivas em tempo de globalização. In: LOPES, Maria Immacolata Vassalo de (org.). Telenovela: internacionalização e interculturalidade. São Paulo: Loyola, 2004.

LOPES, Maria Immacolata Vassallo de. Telenovela como recurso comunicativo. Matrizes, São Paulo, v. 3, n. 1, p. 21-47, 2009.

LOPES, Maria Immacolata Vassallo de; BORELLI, Sílvia; RESENDE, Vera. Vivendo com a Telenovela: mediações, recepção, teleficcionalidade. São Paulo: Summus, 2002.

LOPES, Maria Immacolata Vassallo de.; GÓMEZ, Guilherme Orozco (orgs.). OBITEL 2013. Memória Social e Ficção Televisiva em Países Ibero-Americanos. Porto Alegre: Sulina, 2013.

LOPES, Maria Immacolata Vassallo de; MUNGIOLI, Maria Cristina P. BRASIL: A "nova classe média" e as redes sociais potencializam a ficção televisiva. In: LOPES, Maria Immacolata Vassallo de.; GÓMEZ, Guilherme Orozco (orgs.) OBITEL 2012. Transnacionalização da Ficção Televisiva nos Países Ibero-Americanos. Porto Alegre: Sulina, 2012. 
LOPES, Maria Immacolata Vassallo de; MUNGIOLI, Maria Cristina P. Brasil: a telenovela como fenômeno midiático. In: LOPES, Maria Immacolata Vassallo de.; GÓMEZ, Guilherme Orozco (orgs.). OBITEL 2013. Memória Social e Ficção Televisiva em Países Ibero-Americanos. Porto Alegre: Sulina, 2013.

MACHADO, Irene. Gêneros discursivos. In: BRAIT, Beth (org.). Bakhtin. Conceitoschave. São Paulo: Contexto, 2005.

MACHADO, Uirá. É um erro falar que existe nova classe média, diz sociólogo. Folha de S. Paulo, São Paulo, 13 e fev., 2011. Disponível em:

<http://www1.folha.uol.com.br/poder/2011/02/874777-e-um-erro-falar-que-existenova-classe-media-diz-sociologo.shtml>: Acesso em: abr. 2014.

MAINGUENEAU, Dominique. Análise de Textos de Comunicação. Tradução: Cecília P. de Souza e Décio Rocha. São Paulo: Cortez, 2004.

MAINGUENEAU, Dominique. A propósito do ethos. In: MOTTA, Ana Raquel; SALGADO, Luciana (orgs.). Ethos Discursivo. São Paulo: Contexto, 2008.

MAINGUENEAU, Dominique. Novas Tendências em Análise do Discurso. Tradução: Freda Indursky. Campinas: Pontes/UNICAMP, 1989.

MARTHE, Marcelo. Entrevista João Emanuel Carneiro. O país dos ricos de alma pobre. Revista Veja, São Paulo, n. 27, p. 17-21, 04 julho, 2012a.

MARTHE, Marcelo. Será o apocalipse? Revista Veja, São Paulo, n. 18, p. 134-135, 02 maio, 2012b.

MARTIN-BARBERO, Jesús. Dos meios às mediações. Comunicação, cultura e hegemonia. Tradução: Ronald Polito e Sérgio Alcides. Rio de Janeiro: Editora UFRJ, 2009.

MARX, Karl H. (1867). O Capital: Crítica da Economia Política: Livro I: O processo de produção do capital. Tradução: Rubens Enderlej. São Paulo: Boitempo, 2013.

MARX, Karl H.; ENGELS, Friedrich. (1845-1846). A ideologia alemã. São Paulo: Boitempo, 2007.

MARX, Karl H; ENGELS, Friedrich. (1848). O Manifesto Comunista. Edição eletrônica - Ed.Ridendo Castigat Mores. Versão para E-Book: eBooksBrasil.com., 1999. Disponível em:

<http://www.ebooksbrasil.org/adobeebook/manifestocomunista.pdf>. Acesso em: abr. 2014.

MCCRACKEN, Grant. Cultura \& Consumo. Tradução: Fernanda Eugenio. Rio de Janeiro: Mauad, 2003.

MEYER, Marlyse. Folhetim: uma história. São Paulo: Companhia das Letras, 1996.

MOTTER, Maria Lourdes. A telenovela: documento histórico e lugar de memória. Revista USP, São Paulo, n. 48, p.74-87, 2000-2001. 
MOTTER, Maria Lourdes. Ficção e Realidade: A construção do cotidiano na telenovela. São Paulo: Alexa Cultural, Comunicação \& Cultura - Ficção Televisiva, 2003.

MOTTER, Maria Lourdes; MUNGIOLI, Maria Cristina P. Gênero teledramatúrgico: entre a imposição e a criatividade. Revista USP, São Paulo, n. 76, p. 149-156, dez./fev. 2007-2008.

MOURÃO MACEDO, Renata Guedes. Espelho mágico: empregadas domésticas, consumo e mídia. São Paulo: FFLCH - USP, 2013. 145 p.

MUNGIOLI, Maria Cristina Palma. Ecos da memória da nação na Minissérie Queridos Amigos. Comunicare, São Paulo, v.10, n. 2, p. 54-69, 2010.

MURDOCK, G.. Comunicação contemporânea e questões de classe. Matrizes, São Paulo, v. 2 n. 2, p.31-56, 2009.

NERI, Marcelo Cortes (coord.). A Nova Classe Média: O Lado Brilhante dos Pobres. Rio de Janeiro: FGV/CPS, 2010.

ORTIZ, Renato (org.). Pierre Bourdieu: sociologia. Tradução: Paula Monteiro e Alicia Auzmendi. São Paulo: Ática, 1983.

PADIGLIONE, Cristina. UM BRINDE À CLASSE C. O Estado de S. Paulo, São Paulo, 18 abr. 2012. Caderno 2, p. D5.

PADIGLIONE, Cristina; DEODORO, Juliana. Com maior audiência da TV no ano, final de 'Avenida Brasil' para a cidade. O Estado de S. Paulo, São Paulo, 20 out. 2012. Cidades/Metrópole, p. C6.

POCHMANN, Marcio. Nova Classe Média? O trabalho na base da pirâmide social brasileira. São Paulo: Boitempo, 2012.

PORTAL BRASIL DO GOVERNO FEDERAL. Disponível em: $<$ http://www.brasil.gov.br/noticias/arquivos/2013/04/03/nova-lei-do-trabalhodomestico-comeca-a-valer-a-partir-desta-quarta-feira-3>. Acesso em: jun. 2013.

RESENDE, Viviane de Melo; RAMALHO, Viviane C. V. Sebra. Análise de discurso crítica: uma reflexão acerca dos desdobramentos recentes da teoria social do discurso. Revista ALED, n. 1, p. 27-50, 2005.

RONSINI, Veneza V. Mayora. A Crença no Mérito e a Desigualdade: a recepção da telenovela do horário nobre. Porto Alegre: Sulina, 2012.

RONSINI, Veneza. V. Mayora. Mídia, cultura e classe: a ordem da diferença. In: Encontro Anual Da Associação Nacional dos Programas de Pós-Graduação em Comunicação - Compós, 2007, Curitiba. Anais XVI Compós Encontro Anual da Associação Nacional dos Programas de Pós-graduação em Comunicação. Curitiba: Compós, 2007. p. 16.

SCHAFF, Adam. Linguagem e conhecimento. Coimbra: Almedina, 1974. 
SCHAFF, Adam. O marxismo e o indivíduo. Rio de Janeiro: Civilização Brasileira, 1967.

SOUZA, Jessé. Os Batalhadores Brasileiros: nova classe média ou nova classe trabalhadora? Belo Horizonte: Ed. UFMG, 2012.

SOUZA, Jessé. Para compreender a desigualdade brasileira. Revista Teoria e Cultura, Juiz de Fora, v. 1, n.2, p. 83-100, 2006.

TONDATO, Márcia Perencin. Representações ficcionais à mesa: espaços e estilos de alimentação como diferenciação social. In: Congresso Brasileiro de Ciências da Comunicação - INTERCOM, 2012, Fortaleza. Anais XXXV Congresso Brasileiro de Ciências da Comunicação. Fortaleza: Universidade de Fortaleza. 2012. p. 15.

TONDATO, Marcia Perencin. Viajando com a telenovela: o turismo ficcional como ampliação de universos simbólicos e materiais. Revista Comunicación, v.1, n. 10, p.1031-1046, 2012.

TRINDADE, Eneus; PEREZ, Clotilde. Dimensões do consumo midiatizado. In: II Congresso Mundial de Comunicação Ibero-Americana - CONFIBERCOM, 2014, Braga. Anais II Confibercom. Braga: Universidade do Minho, 2014. p. 9.

TRINDADE, Eneus; PEREZ, Clotilde. Rituais de Consumo: dispositivos midiáticos de articulação de vínculos de sentidos entre marcas e consumidores. In: IX Seminário Internacional Imagem da Cultura. Cultura das Imagens, 2013, São Paulo. Anais IX Seminário Internacional Imagem da Cultura. Cultura das Imagens. São Paulo: ECA/USP, 2013. p.12.

VIGOTSKI, Lev Semenovitch. Pensamento e linguagem. São Paulo: Martins Fontes, 2005.

VOLOCHINOV, V. N./BAKHTIN, Mikhail. (1926). Discurso na vida e discurso na arte. Sobre poética sociológica. Trad. para uso didático por C. Tezza e C. A. Faraco, s.d.

VOZES DA CLASSE MÉDIA. Brasília: Marco Zero, 2012.

WEBER, Max. A ética protestante e o espírito do capitalismo. São Paulo: Martin Claret, 2005.

WILLIAMS, Raymond. Cultura e materialismo. São Paulo: Editora Unesp, 2011. 